CLAUDIA MARIA BERTAN

MECANISMOS ENDÓCRINOS E MOLECULARES PELOS QUAIS O ESTRADIOL ESTIMULA A SÍNTESE DE PROSTAGLANDINA F2 $\alpha$ NO ENDOMÉTRIO DE FÊMEAS BOVINAS

São Paulo

2004 


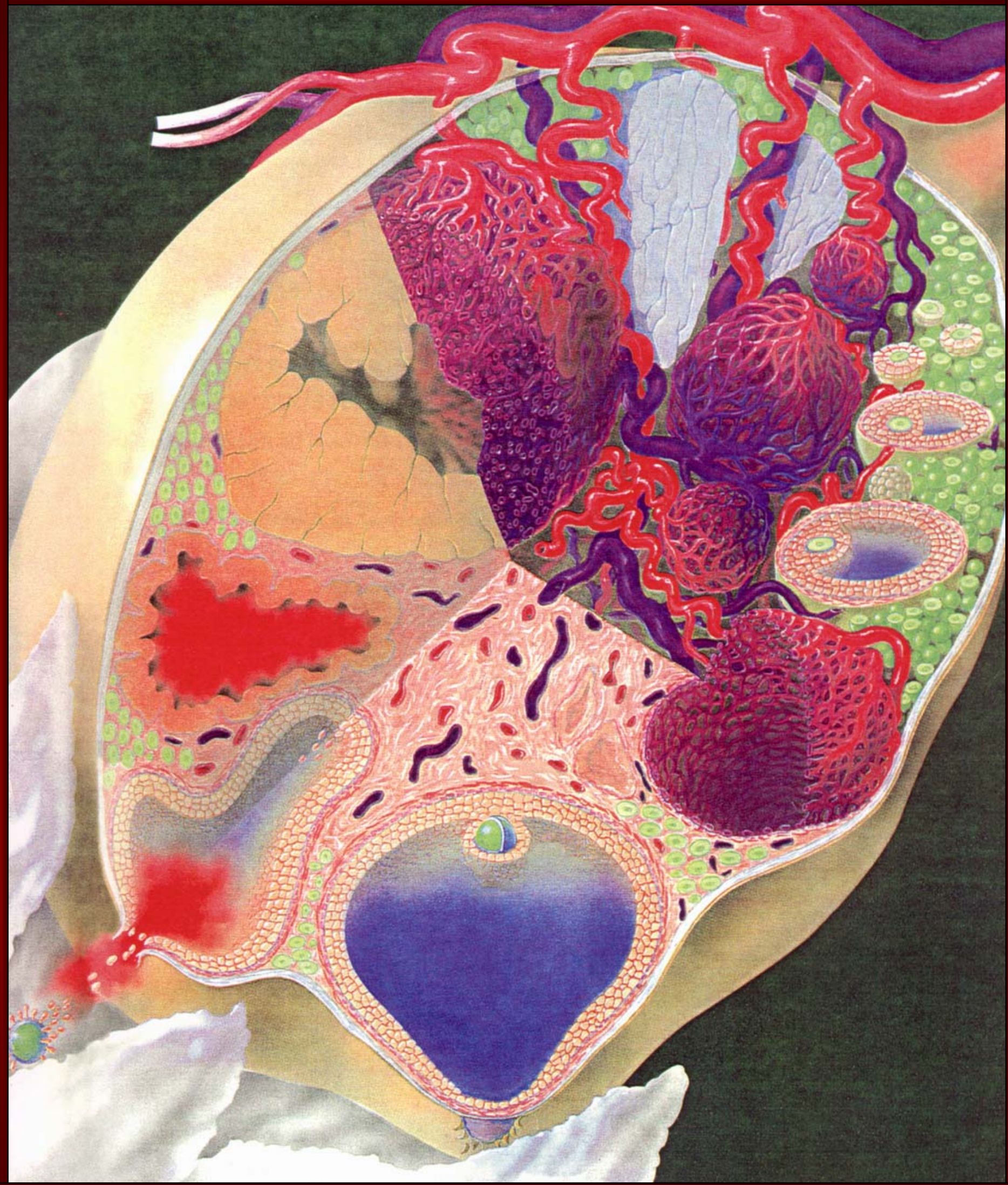

Mecanismos endócrinos e moleculares pelos quais o estradiol estimula a sintese de prostaglandina $F 2 \alpha$ no endométrio de fêmeas 6ovinas 


\section{MECANISMOS ENDÓCRINOS E MOLECULARES PELOS QUAIS O ESTRADIOL ESTIMULA A SÍNTESE DE PROSTAGLANDINA F2 $\alpha$ NO ENDOMÉTRIO DE FÊMEAS BOVINAS}

Tese apresentada ao Programa de Pós-Graduação em Reprodução Animal da Faculdade de Medicina Veterinária e Zootecnia da Universidade de São Paulo, para obtenção do título de Doutora em Medicina Veterinária

Departamento:

Reprodução Animal

Área de concentração:

Reprodução Animal

Orientador:

Prof. Dr. Mario Binelli 
Autorizo a reprodução parcial ou total desta obra, para fins acadêmicos, desde que citada a fonte.

DADOS INTERNACIONAIS DE CATALOGAÇÃO-NA-PUBLICAÇÃO

(Biblioteca da Faculdade de Medicina Veterinária e Zootecnia da Universidade de São Paulo)

T. 1445 Bertan, Claudia Maria

FMVZ Mecanismos endócrinos e moleculares pelos quais o estradiol estimula a síntese de prostaglandina F2 $\alpha$ no endométrio de fêmeas bovinas / Claudia Maria Bertan. - São Paulo : C. M. Bertan, 2004. $180 \mathrm{f}$ : : il.

Tese (doutorado) - Universidade de São Paulo. Faculdade de Medicina Veterinária e Zootecnia. Departamento de Reprodução Animal, 2004.

Programa de Pós-graduação: Reprodução Animal.

Área de concentração: Reprodução Animal.

Orientador: Prof. Dr. Mario Binelli.

1. Estradiol. 2. Endométrio. 3. Luteólise. 4. PG F2 $\alpha$. 5. Bovinos. I. Título. 


\section{ERRATA}

Página

Linha

Onde se lê

Leia-se

RESUMO

3

endometrial

no endométrio

ABSTRACT

3

endometrial

no endométrio 


\section{UNIVERSIDADE DE SÃO PAULO \\ Faculdade de Medicina Veterinária e Zootecnia \\ Cidade Universitária "Armando de Salles Oliveira" \\ Comissão Bioética \\ CERTIFICADO}

Certificamos que o Projeto intitulado "O papel do estradiol na luteólise de fêmeas bovinas", Protocolo $\mathrm{n}^{\circ}$ 273/2003, sob a responsabilidade do Prof. Dr. Mario Binelli, utilizando 17 novilhas cruzadas e 15 vacas holandesas, está de acordo com os princípios éticos de experimentação animal da Comissão de Bioética da Faculdade de Medicina Veterinária e Zootecnia da Universidade de São Paulo e foi aprovado pela referida Comissão, em sessão de 23/04/2003.

(We certify that the Research "Role of estradiol in the luteolysis of cows" protocol number 273/2003, under the responsability of Prof. Dr. Mario Binelli, utilizing 32 cows, agree with Ethical Principles in Animal Research adopted by Bioethic Commission of the Faculty of Veterinary Medicine and Zootechny of University of São Paulo and was approved in 04/23/2003 meeting.

São Paulo, 24 de abril de 2003

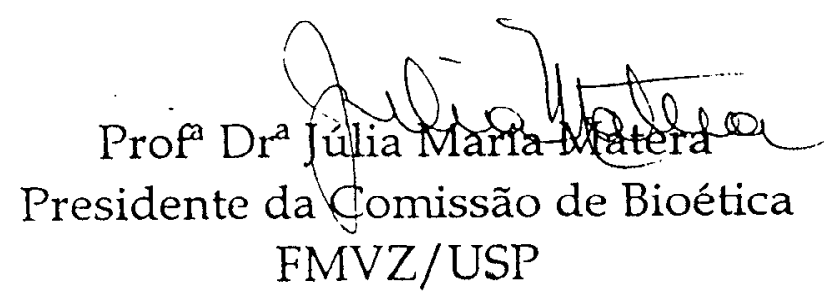




\section{FOLHA DE AVALIAÇÃO}

Nome do Autor: BERTAN, Claudia Maria

Título: Mecanismos endócrinos e moleculares pelos quais o estradiol estimula a síntese de prostaglandina F2 $\alpha$ no endométrio de fêmeas bovinas

Tese apresentada ao Programa de Pós-Graduação em Reprodução Animal da Faculdade de Medicina Veterinária e Zootecnia da Universidade de São Paulo, para obtenção do título de Doutora em Medicina Veterinária

Data:

\section{Banca Examinadora}

Prof. Dr.:

Assinatura:

Prof. Dr.:

Assinatura:

Prof. Dr.:

Assinatura:

Prof. Dr.:

Assinatura:

Prof. Dr.:

Assinatura:
Instituição:

Julgamento:

Instituição:

Julgamento:

Instituição:

Julgamento:

Instituição:

Julgamento:

Instituição:

Julgamento: 
Aos meus queridos e amados filhos, Carolina e Angelo, vocês são a minha felicidade, inspiração e aprendizado, os verdadeiros incentivadores dos projetos de vida da mamãe. 
Aos meus pais, João e Nezita, pelos ensinamentos, pelo imenso carinho e amor dedicado a mim e aos meus filhos. Pela ajuda incondicional concedida durante toda a minha vida. Vocês são o verdadeiro exemplo de amor. 
“O estudo da gramática não faz poetas. O estudo da harmonia não faz compositores. O estudo da psicologia não faz pessoas equilibradas. O estudo das "ciências da educação" não faz educadores. Educadores não podem ser produzidos. Educadores nascem. O que se pode fazer é ajudá-los a nascer. Pela educação o indivíduo se torna mais apto para viver, aprende a pensar e a resolver os problemas práticos da vida. Pela educação ele se torna mais sensível e mais rico interiormente, o que faz dele uma pessoa mais bonita, mais feliz e mais capaz de conviver com os outros. A maioria dos problemas da sociedade se resolveria se os indivíduos tivessem aprendido a pensar."

\section{Rubem Alves}

Em especial ao Prof. Dr. Mario Binelli, que ao estender-me sua mão conduziu-me ao caminho da ciência. À você minha mais profunda admiração, gratidão e respeito. 


\section{AGRADECIMENTOS}

Ao Prof. Dr. Renato Campanarut Barnabé, pela primeira oportunidade oferecida de integrar o Departamento de Reprodução Animal desta Faculdade, e pelo inestimável carinho com que sempre me recebeu.

Ao Prof. Dr. Cláudio Alvarenga de Oliveira, Presidente da Comissão de Pós-Graduação do Departamento de Reprodução Animal, pelo incentivo constante.

Ao Prof. Dr. José Antônio Visintin, pelo apoio e amizade.

Ao Prof. Dr. Ed Hoffmann Madureira, por todos os ensinamentos oferecidos, mas principalmente, pela amizade, compreensão e apoio.

Ao Prof. Dr. Rubens Paes de Arruda, pela atenção sempre concedida.

À Profa. Dra. Anneliese de Souza Traldi, pela verdadeira e valiosa amizade. Vou sentir muita falta das nossas longas conversas e das nossas boas risadas.

A todos os professores do Departamento de Reprodução Animal, pelos ensinamentos.

Ao Prof. Dr. William Thatcher, da Universidade da Flórida, pela doação dos anticorpos de PGF2 $\alpha$ e PFGM, utilizados nas técnicas de radioimunoensaio e pela doação das células BEND.

Ao Dr. Aydyn Guzeloglu, da Universidade da Flórida pelo processamento das células BEND.

À querida Profa. Dra. Thaís Diaz, da Universidade de Caracas, pelos seus ensinamentos, pela sua amizade e carinho.

Ao Prof. Dr. Marcelo de Cerqueira Cesar, do Departamento de Ciências Básicas, da Faculdade de Zootecnia e Engenharia de Alimentos da Universidade de São Paulo, pela valiosa contribuição científica, meu profundo respeito e gratidão.

A Profa. Dra. Heloísa S. Celistre de Araújo, do Departamento de Ciências Fisiológicas, da Universidade Federal de São Carlos e a Profa. Dra. Catarina Porto, da Faculdade Paulista de Medicina, pela discussão dos resultados e contribuição científica ao projeto.

Ao Prof. Dr. Flávio Meirelles, do Departamento de Ciências Básicas, da Faculdade de Zootecnia e Engenharia de Alimentos da Universidade de São Paulo, pela contribuição científica e logística nos experimentos realizados com células BEND.

Ao Prof. Dr. Paulo Henrique Mazza Rodrigues pelos ensinamentos em estatística.

Ao Prof. Dr. Ciro Moraes Barros e Prof. Dr. José Buratini Júnior, do Departamento de Farmacologia e Fisiologia da UNESP de Botucatu, pelo auxílio científico e técnico. 
Ao Prof. Dr. Guilherme de Paula Nogueira, do Departamento de Ciências Básicas da UNESP de Araçatuba, pelo auxílio fundamental que nos prestou durante a execução deste trabalho.

Aos meus amigos de equipe, Luiz Augusto de Castro e Paula, João Gustavo Pereira Loureiro, Priscila Jorge, Angelo Bertholazzi, Fabiana Fernandes Bressan, Marcelo Demarchi Goissis, Vanessa Belentani Marques, Patrícia Helena Míguez e Jamile Martins Viana, pela grande amizade e colaboração na execução dos experimentos realizados, mas principalmente pelo agradável convívio. Aos estagiários David Fantini, Luciana Parra, Flávia de Barros e Rafael Meneghini, pelo valioso auxílio durante a execução dos experimentos.

A minha especial companheira de equipe e grande amiga Pauline Martins da Cunha, pelo grande carinho dispensado a mim e aos meus filhos. Os momentos difíceis da vida podem ser uma ótima oportunidade para reconhecermos os verdadeiros amigos. Obrigada ainda por compartilhar das minhas idéias sobre os homens.

Aos amigos de longa data, Eneiva Carla Carvalho Celeghini, Norma Lúcia de Souza e Roberta Mara Züge, por todos os momentos de carinho e atenção. Ao meu grande amigo Marcelo Rezende Luz, pela sua verdadeira amizade, já sinto falta das nossas maravilhosas conversas. Vocês são a confirmação de que os amigos aparecem em nossa vida por acaso, mas não é por acaso que permanecem.

Aos meus amigos de pós-graduação, Katia Mizuta, João Paulo Barbuio, Alexandre Marques, Alexandre Rossetto Garcia, Rodrigo Alonso Forero Gonzalez, Pércio Gaspar, José Rodrigo Valim Pimentel, Alexandre Barreto de Almeida, Graziela Barreto de Almeida, Luiz Augusto Ferreira Rossa, Maria Fernanda Loureiro, Adriana Capezutto e André Luis Granito.

À Giselle Ayres, minha querida amiga e conselheira de todas as horas.

À Giovana Krempel Fonseca Merighe, pela atenção e amizade.

As minhas amigas Silvana Picolli Pugine e Viviane Nunes, pelo carinho no auxílio nas técnicas de cromatografia, mas principalmente pelos inúmeros momentos felizes que passamos juntas. A minha querida amiga Betinha (in memoriam) pela sua valiosa amizade e grande capacidade de tornar qualquer dia em um bom dia para as pessoas com as quais convivia. Você sempre será lembrada com muito carinho.

À Fundação de Amparo à Pesquisa do Estado de São Paulo (FAPESP), pela concessão da bolsa de doutorado, pelo suporte financeiro e logístico ao projeto e principalmente pela confiança depositada. Pela oportunidade que possibilitou minha formação e capacitação científica, além do envolvimento integral no projeto de pesquisa o que resultou em dados experimentais de grande confiabilidade.

Ao biotério central da Universidade de São Paulo da cidade de Ribeirão Preto e ao Centro de Pesquisa Toxicológica Veterinária "CEPTOX” da Faculdade de Medicina Veterinária e Zootecnia, da Universidade de São Paulo pela contribuição. 
À Isabel Barbosa, pela amizade e pela boa vontade em resolver nossos problemas burocráticos.

Á Cleusa Catice Pagotti, pela atenção e carinho.

A secretaria de pós-graduação Harumi Doi Shiraishi e a secretária do Departamento de Reprodução Animal Thaís Soto, meus sinceros agradecimentos pelo empenho burocrático e pela gentileza.

Aos funcionários, Márcio e José Maria pelo auxílio no manejo dos animais durante todo o período experimental.

Aos funcionários da Prefeitura do Campus Administrativo de Pirassununga e da FMVZ, em especial aos funcionários do Abatedouro, Seção de Transportes e Setor de Gado de Corte, por toda a colaboração e boa vontade sempre concedida.

A todos que diretamente ou indiretamente contribuíram no planejamento e execução dos experimentos desenvolvidos na presente tese. 
"Se não houver frutos, valeu a beleza das flores se não houver flores, valeu a sombra das folhas se não houver folhas, valeu a intenção da semente.

A semente foi lançada, e mesmo que não tenha existido a sombra das folhas, a beleza das flores e a colheita dos frutos, mesmo assim, valeu a experiência de tornar-se uma semeadora".

Ao Umberto, pela dedicação aos nossos filhos durante os primeiros dois anos de doutorado. 
"Quando nada parece ajudar, eu vou e olho o cortador de pedras martelando sua rocha talvez cem vezes sem que nem uma só rachadura apareça. No entanto, na centésima primeira martelada, a pedra se abre em duas, e sei que não foi aquela que a conseguiu, mas todas as outras que vieram antes".

Jacobs Riis 


\section{RESUMO}

BERTAN, C.M. Mecanismos endócrinos e moleculares pelos quais o estradiol estimula a síntese de prostaglandina F2 $\alpha$ endometrial em fêmeas bovinas. [Endocrine and molecular mechanisms by which estradiol stimulates endometrial prostaglandin F2 $\alpha$ synthesis in the cow]. 2004. $180 \mathrm{f}$. Tese (Doutorado em Medicina Veterinária) - Faculdade de Medicina Veterinária e Zootecnia, Universidade de São Paulo, São Paulo, 2004.

$\mathrm{O}$ estradiol $\left(\mathrm{E}_{2}\right)$ é requerido para a luteólise de fêmeas bovinas e injeções de $\mathrm{E}_{2}$ estimulam a liberação de prostaglandina $\mathrm{F} 2 \alpha(\mathrm{PGF} 2 \alpha)$. É possível que o $\mathrm{E}_{2}$ estimule a síntese e/ou a atividade de moléculas envolvidas na cascata geradora de PGF2 $\alpha$, como enzimas e receptores para outros ligantes. O cálcio é um conhecido cofator para a proteína quinase $\mathrm{C}$ e fosfolipase $\mathrm{A}_{2}$, enzimas envolvidas na produção PGF2 $\alpha$. O objetivo geral desse estudo foi investigar os mecanismos endócrinos e moleculares estimulados pelo $\mathrm{E}_{2}$ durante a luteólise. No experimento 1, vacas holandesas não lactantes foram tratadas com 3mg de $\mathrm{E}_{2} \operatorname{nos} \operatorname{dias} 13$ ( $\left.\mathrm{n}=2\right), 15$ ( $\left.\mathrm{n}=2\right), 17$ $(n=3)$ e $19(n=5)$ do ciclo estral e a produção de PGFM (metabólito plasmático da PGF2 $\alpha$ ) mensurada por radioimunoensaio. Concluiu-se que a administração de $\mathrm{E}_{2}$ no $17^{\circ}$ dia do ciclo estral constitui um modelo experimental adequado para determinar os mecanismos envolvidos na síntese de PGF2 $\alpha$. O experimento 2, foi realizado para investigar o papel do $\mathrm{E}_{2}$ na cascata produtora de PGF2 $\alpha$. Novilhas cruzadas de corte, cíclicas, não lactantes, foram pareadas no dia 17 de um ciclo estral sincronizado, injetadas com $0(n=6)$ ou $3 m g$ de $E_{2}(n=7)$ e abatidas 2 horas após. Explantes endometriais foram tratados com os seguintes estimuladores da síntese de PGF2 $\alpha$ : ionóforo de cálcio (CI), melitina ou ocitocina. Explantes foram incubados em quadruplicata e amostras de meio foram coletadas imediatamente e 60 minutos após o início da cultura. As concentrações de PGF2 $\alpha$ foram mensuradas por radioimunoensaio. Explantes endometriais tratados in vitro com CI tiveram um incremento na síntese de PGF2 $\alpha$ de 48,41\% quando foram previamente tratados com o $\mathrm{E}_{2}(\mathrm{P} \leq 0,01)$. No experimento 3, células endometriais bovinas (células BEND) foram tratadas com $0,10^{-7}, 10^{-6}$ ou $10^{-5} \mathrm{M} \mathrm{CI}$ por $12 \mathrm{~h}$ em triplicata, em três experimentos independentes. As concentrações de $10^{-6}$ e $10^{-5} \mathrm{M}$ de CI estimularam a produção de PGF2 $\alpha$ em comparação às outras concentrações $(\mathrm{P} \leq 0,05)$. No experimento 4 , células $\mathrm{BEND}$ receberam 0 ou $10^{-13} \mathrm{M} \mathrm{E}_{2}$ e 0 ou $10^{-6} \mathrm{M}$ CI em um arranjo fatorial $2 \times 2$, durante $12 \mathrm{~h}$ em triplicata, em três experimentos independentes. A produção de PGF2 $\alpha$ foi de 33,1; 32,5; 92,4 e 145,6 (EPM: 21,8) pg/mL para células não tratadas, tratadas com $\mathrm{E}_{2}, \mathrm{CI}$ e $\mathrm{E}_{2}+\mathrm{CI}$, respectivamente. Houve uma tendência do tratamento com $\mathrm{CI}$ estimular a produção de $\mathrm{PGF} 2 \alpha(\mathrm{P} \leq 0,08)$, entretanto, na presença de $\mathrm{E}_{2}$ o CI estimulou significativamente a síntese de $\mathrm{PGF} 2 \alpha(\mathrm{P} \leq 0,01)$. Conclui-se que em fêmeas bovinas o $\mathrm{E}_{2}$ potencializou os efeitos do $\mathrm{CI}$ na síntese de PGF2 $\alpha$ endometrial. Propõe-se que o $\mathrm{E}_{2}$ ativa a síntese de enzimas que, estimuladas pelo cálcio, atuam na síntese de PGF2 $\alpha$ endometrial.

Unitermos: Estradiol. Endométrio. Luteólise. PGF2 $\alpha$. Bovinos. 


\begin{abstract}
BERTAN, C.M. Endocrine and molecular mechanisms by which estradiol stimulates endometrial prostaglandin F2 $\alpha$ synthesis in the cow. [Mecanismos endócrinos e moleculares pelos quais o estradiol estimula a síntese de prostaglandina F2 $\alpha$ endometrial em fêmeas bovinas]. 2004. 180 f. Tese (Doutorado em Medicina Veterinária) - Faculdade de Medicina Veterinária e Zootecnia, Universidade de São Paulo, São Paulo,
\end{abstract} 2004.

Estradiol $\left(\mathrm{E}_{2}\right)$ is required for luteolysis in bovine female and $\mathrm{E}_{2}$ injections stimulate prostaglandin F2 $\alpha$ (PGF2 $\alpha$ ) release. It is possible that $\mathrm{E}_{2}$ stimulates synthesis and/or activity of molecules in the cascade of PGF $2 \alpha$ production, such as enzymes and receptors to other ligands. Calcium is a known cofactor for protein kinase $\mathrm{C}$ and phospholipase $\mathrm{A}_{2}$, enzymes involved in PGF2 $\alpha$ production. The main goal of this study was to investigate endocrine and molecular mechanisms stimulated by $\mathrm{E}_{2}$ during luteolysis. In experiment 1, non-lactating Holstein cows were treated with $3 \mathrm{mg} \mathrm{E}_{2}$ on days $13(\mathrm{n}=2), 15(\mathrm{n}=2), 17(\mathrm{n}=3)$ or $19(\mathrm{n}=5)$ of the day estrous cycle and production PGFM (a PGF2 $\alpha$ plasma metabolite) was evaluated by radioimmunassay. It was concluded that $\mathrm{E}_{2}$ administration on day 17 of the cycle was an adequate experimental model to determine mechanisms involved in endometrial PGF2 $\alpha$ synthesis. Experiment 2 was designed in order to investigate the role of $E_{2}$ in the enzymatic cascade of PGF2 $\alpha$ production. Cyclic, cross-bred beef heifers were paired on day 17 of a synchronized estrous cycle, injected with $0(n=6)$ or $3 \mathrm{mg}$ of $\mathrm{E}_{2}(\mathrm{n}=7)$ and slaughtered after two hours. Endometrial explants were treated with stimulators of the cascade of PGF2 $\alpha$ synthesis, i.e., calcium ionophore (CI), melittin or oxytocin. Explants were incubated in quadruplicate and medium samples were collected immediately and 60min after to begin culture. The concentrations PGF2 $\alpha$ were measured by radioimmunoassay. Endometrial explants in vitro treatment with CI production the $\mathrm{PGF} 2 \alpha$ was $48,41 \%$ higher in from cows treated with $\mathrm{E}_{2}(\mathrm{P} \leq 0,01)$. In experiment 3 , bovine endometrium cells (BEND cells) were treated with $0,10^{-7}, 10^{-6}$ or $10^{-5} \mathrm{M}$ CI for $12 \mathrm{~h}$ in triplicate, in three independent experiments. The $10^{-6}$ and $10^{-5} \mathrm{M}$ concentrations of $\mathrm{CI}$ stimulated production of PGF2 $\alpha$ in comparison to other concentrations $(\mathrm{P} \leq 0,05)$. In experiment 4 , BEND cells received 0 or $10^{-13} \mathrm{M} \mathrm{E}_{2}$ and 0 or $10^{-6} \mathrm{M} \mathrm{CI}$ in a $2 \times 2$ factorial arrangement, for $12 \mathrm{~h}$ in triplicate cultures in three independent experiments. Production of PGF2 $\alpha$ was 33.1, 32.5, 92.4 and 145.6 (pooled SEM: 21.8) pg/mL for cells treated with nothing, $E_{2}, C I$ and $E_{2}+C I$, respectively. Treatment with $C I$ alone tended to stimulate PGF2 $\alpha$ production $(\mathrm{P} \leq 0,08)$, however, in the presence of $\mathrm{E}_{2}, \mathrm{CI}$ significantly stimulated $\mathrm{PGF} 2 \alpha$ synthesis $(\mathrm{P} \leq 0,01)$. It was concluded that in bovine female the $\mathrm{E}_{2}$ improved the CI effects in endometrial PGF2 $\alpha$ synthesis. It proposes that $\mathrm{E}_{2}$ active the enzyme synthesis that, calcium stimulated, actuate in endometrial PGF2 $\alpha$ synthesis.

Key words: Estradiol. Endometrium. Luteolysis. PGF2 $\alpha$. Bovine. 


\section{LISTA DE FIGURAS}

Figura 1 - Esquema ilustrando a biossíntese de PGF2 $\alpha$ a partir do ácido araquidônico nas células endometriais bovinas, segundo modelo proposto por Burns et al., 1997. A OT (OT) se liga ao seu receptor (OT-R) e este associa-se à proteína G (G) e ativa a fosfolipase C (PLC) que cliva o fosfatidilinositol bifosfato $\left(\mathrm{PIP}_{2}\right)$ em inositol trifosfato $\left(\mathrm{IP}_{3}\right)$ e diacilglicerol (DAG). O IP 3 se liga a receptores específicos no retículo endoplasmático, permitindo a liberação de cálcio $\left(\mathrm{Ca}^{++}\right)$para o citosol. O DAG e o cálcio ativam a proteína quinase $\mathrm{C}$ (PKC). A PKC juntamente com o cálcio fosforila a fosfolipase $\mathrm{A}_{2}\left(\mathrm{PLA}_{2}\right)$ que cliva o ácido araquidônico (AA). A seguir, o AA livre é convertido a prostaglandina $\mathrm{H}_{2}\left(\mathrm{PGH}_{2}\right)$ pela enzima ciclooxigenase $2(\mathrm{COX}-2) . \mathrm{A} \mathrm{PGH}_{2}$ é convertida à prostaglandina PGF2 $\alpha$ (PGF2 $\alpha)$ pela ação da PGF sintase (PGFS)

Figura 2 - Esquema ilustrando a biossíntese de PGF2 $\alpha$ a partir do ácido araquidônico proposto por Burns et al. (1997) e o ponto de estimulação específico na cascata pelo ionóforo de cálcio, melitina e ocitocia nas células endometriais bovinas

Figura 3 - Modelo hipotético ilustrando os possíveis mecanismos de atuação do $E_{2}: \mathrm{o}_{2}$ estimularia a síntese das enzimas PKC e PLA 2 dependentes de cálcio e/ou (A); o $E_{2}$ atuaria nos canais de cálcio aumentando a concentração intracelular de cálcio que associado ao CI promoveria a estimulação máxima da síntese de PGF2 $\alpha$ (B); o $E_{2}$ participaria mediando a síntese e/ou a ativação de ERK1/2, JNK/SAPK e p38 MAPK que associadas ao CI ativariam PKC e $\mathrm{PLA}_{2}$ estimulando a síntese de PGF2 $\alpha$ no endométrio bovino (C). Mecanismo de ação do CI como transportador iônico, promovendo a entrada do íon cálcio $(\bullet)$ e a saída dos íons de hidrogênio $(\bullet)$ do compartimento celular (D). 
Figura 4 - Procedimento de canulação da veia jugular. a) Tricotomia e assepsia no local da inserção do cateter; b) Introdução da agulha e do cateter; c) Aplicação da solução de citrato de sódio a 3,5\%; d) "Patch" fixado a pele do animal e verificação das condições de funcionamento cânula............................................

Figura 5 - Procedimentos de incubação dos explantes edometriais em banho-maria com agitação (Dubnoff Shaker)

Figura 6 - Esquema do sistema de cultura de tecido endometrial por incubação. 


\section{LISTA DE FIGURAS}

Gráfico 1 - Concentrações de PGFM das vacas tratadas com 17ß-estradiol (3mg; hora 2) e OT (50 UI; hora 9) nos dias $13(n=2), 15(n=2), 17(n=3)$ e $19(n=5)$ do ciclo estral - Pirassununga - Jun 2002

Gráfico 2 - Concentrações de basal, pico e diferença pico-basal de PGFM de vacas holandesas nos dias $13(n=2), 15(n=2), 17(n=3)$ e $19(n=5)$ do ciclo estral (ver texto) - Pirassununga - Jun 2002

Gráfico 3 - Produção média de PGF2 $\alpha$ (DIF 60; LSmeans \pm EPM) de explantes endometriais de vacas no $17^{\circ}$ dia do ciclo estral tratadas com $0(n=6)$ ou 3 mg de $17 \beta$-estradiol $(\mathrm{n}=7)$ tratados ou não in vitro com $\mathrm{CI} 10^{-5} \mathrm{M}$, Melitina $10^{-5} \mathrm{M}$ ou OT $10^{-6} \mathrm{M}$ - Pirassununga - Jan. 2002 a Dez. 2003

Gráfico 4 - Produção média (LSmeans \pm EPM) de PGF2 $\alpha(\mathrm{pg} / \mathrm{mL} / \mathrm{mg}$ de tecido) por células BEND tratadas com $0,10^{-7}, 10^{-6}$ ou $10^{-5} \mathrm{M}$ de ionóforo de cálcio por 12 horas - Pirassununga - Jun. 2003 a Dez. 2003

Gráfico 5 - Produção média (LSmeans \pm EPM) de PGF2 $\alpha(\mathrm{pg} / \mathrm{mL} / \mathrm{mg}$ de tecido) por células BEND tratadas com 0 ou $10^{-13} \mathrm{M}$ de $\mathrm{E}_{2}$ e/ou 0 ou $10^{-6} \mathrm{M}$ de ionóforo de cálcio por 12 horas - Pirassununga - Jan. 2004 a Abr. 2004 


\section{LISTA DE TABELAS}

Tabela 1 - Análise de variância dos quadrados mínimos da concentração plasmática de PGFM de vacas nos dias $13(\mathrm{n}=2), 15(\mathrm{n}=2), 17(\mathrm{n}=3)$ ou $19(\mathrm{n}=5)$ do ciclo estral, submetidas a tratamento com $3 \mathrm{mg}$ de $17 \beta$-estradiol - Pirassununga Jun 2002

Tabela 2 - Análise de variância dos quadrados mínimos das concentrações basais, pico basal e pico/basal de PGFM em vacas nos dias 13 (n=2), $15(n=2), 17(n=3)$ ou $19(\mathrm{n}=5)$ do ciclo estral, submetidas ao tratamento com $3 \mathrm{mg}$ de $17 \beta$ estradiol - Pirassununga - Jun 2002.

Tabela 3 - Análise de variância dos quadrados mínimos da produção de PGF2 $\alpha$ (DIF 60) por explantes endometriais de vacas no $17^{\circ}$ dia do ciclo estral tratadas com $0(\mathrm{n}=6)$ ou $3 \mathrm{mg}$ de $17 \beta$-estradiol $(\mathrm{n}=7)$ in vivo para testar o efeito do meio KHB suplementado com Ionóforo de Cálcio $10^{-5} \mathrm{M}$, Melitina $10^{-5} \mathrm{M}$ ou Ocitocina $10^{-6} \mathrm{M}$ pareados com o meio de cultivo KHB - Pirassununga - Jan. 2002 a Dez. 2003

Tabela 4 - Média dos quadrados mínimos da produção de PGF2 $\alpha$ (DIF 60) \pm SEM comparadas por contrastes ortogonais de explantes endometriais de vacas no $17^{\circ}$ dia do ciclo estral tratadas com $0(n=6)$ ou $3 \mathrm{mg}$ de $17 \beta$-estradiol $(\mathrm{n}=7)$ tratados ou não in vitro com CI $10^{-5} \mathrm{M}$, Melitina $10^{-5} \mathrm{M}$ ou OT $10^{-6} \mathrm{M}$ Pirassununga - Jan. 2002 a Dez. 2003

Tabela 5 - Análise de variância dos quadrados mínimos da produção de PGF2 $\alpha$ (DIF 12) em células BEND em meio de cultivo suplementado com $0 \mathrm{M}, 10^{-7} \mathrm{M}$, $10^{-6} \mathrm{M}$ ou $10^{-5} \mathrm{M}$ de Ionóforo de Cálcio - Pirassununga - Jun. 2003 a Dez. 2003. 
Tabela 6 - Análise de variância dos quadrados mínimos da produção de PGF2 $\alpha$ (DIF 12) em células BEND tratadas com em meio de cultivo suplementado com $0 \mathrm{M}$ ou $10^{-13} \mathrm{M}$ de $\mathrm{E}_{2}$ associados a $0 \mathrm{M}$ ou, $10^{-6} \mathrm{M}$ de Ionóforo de Cálcio Pirassununga - Jan. 2004 a Abr. 2004 .............................................................. 


\section{LISTA DE ABREVIATURAS E DE SIGLAS}

\begin{tabular}{|c|c|}
\hline $\mathrm{AA}$ & ácido araquidônico \\
\hline $\mathrm{AMPc}$ & adenosina monofosfato cíclica \\
\hline BEND & bovine endometrial cells \\
\hline${ }^{\circ} \mathrm{C}$ & graus Celsius \\
\hline CAP-527 & antagonista dos receptores de ocitocina \\
\hline $\mathrm{CI}$ & ionóforo de cálcio \\
\hline CIDR & dispositivo intravaginal de liberação controlada de progesterona \\
\hline $\mathrm{CL}$ & corpo lúteo \\
\hline $\mathrm{cm}$ & centímetro \\
\hline $\mathrm{CO}_{2}$ & dióxido de carbono \\
\hline $\mathrm{COX}-2$ & ciclooxigenase 2 \\
\hline $\mathrm{D}$ & dia do ciclo estral \\
\hline DAG & diacilglicerol \\
\hline DMSO & dimetilsulfóxido \\
\hline DNA & ácido desoxirribonucleico \\
\hline $\mathrm{DPM}$ & desintegrações por minuto \\
\hline $\mathrm{E}_{2}$ & estradiol \\
\hline EPM & erro padrão da média \\
\hline ER & receptores de estrógeno \\
\hline ERK & quinases reguladas por sinais extracelulares \\
\hline ET1 & endotelina tipo 1 \\
\hline FSH & hormônio folículo estimulante \\
\hline G & gauges \\
\hline $\mathrm{g}$ & grama \\
\hline$g$ & gravidade \\
\hline G & proteína $\mathrm{G}$ \\
\hline
\end{tabular}




\begin{tabular}{|c|c|}
\hline GH & hormônio de crescimento \\
\hline GnRH & hormônio liberador de gonadotrofinas \\
\hline GTP & guanosina trifosfato \\
\hline $\mathrm{h}$ & horas \\
\hline hCG & gonadotrofina coriônica humana \\
\hline HDL & lipoproteína de alta densidade \\
\hline${ }^{3} \mathrm{H}$ & trício \\
\hline${ }^{3} \mathrm{H}-\mathrm{PGF} 2 \alpha$ & prostaglandina $F 2 \alpha$ marcada com trício \\
\hline${ }^{3} \mathrm{H}-\mathrm{PGFM}$ & 13,14-diidro-15-ceto-prostaglandina F2 $\alpha$ marcada com trício \\
\hline IFN- $\tau$ & interferon $\tau$ \\
\hline IM & intramuscular \\
\hline $\mathrm{IP}_{3}$ & trifosfato inositol \\
\hline IV & intravenosa \\
\hline JNK & c-Jun quinase \\
\hline $\mathrm{kDa}$ & quilodaltons \\
\hline $\mathrm{Kg}$ & quilograma \\
\hline KHB & bicarbonato Krebs-Hensleit \\
\hline $\mathrm{L}$ & litro \\
\hline LDL & lipoproteína de baixa densidade \\
\hline LH & hormônio luteinizante \\
\hline LLC & células luteais grandes \\
\hline M & molar \\
\hline MAPK & quinases ativadas por mitógenos \\
\hline MCP-1 & proteína monoquimioatrativa tipo 1 \\
\hline $\mathrm{mg}$ & micrograma \\
\hline $\mathrm{mL}$ & mililitro \\
\hline $\mathrm{mm}$ & milímetro \\
\hline
\end{tabular}




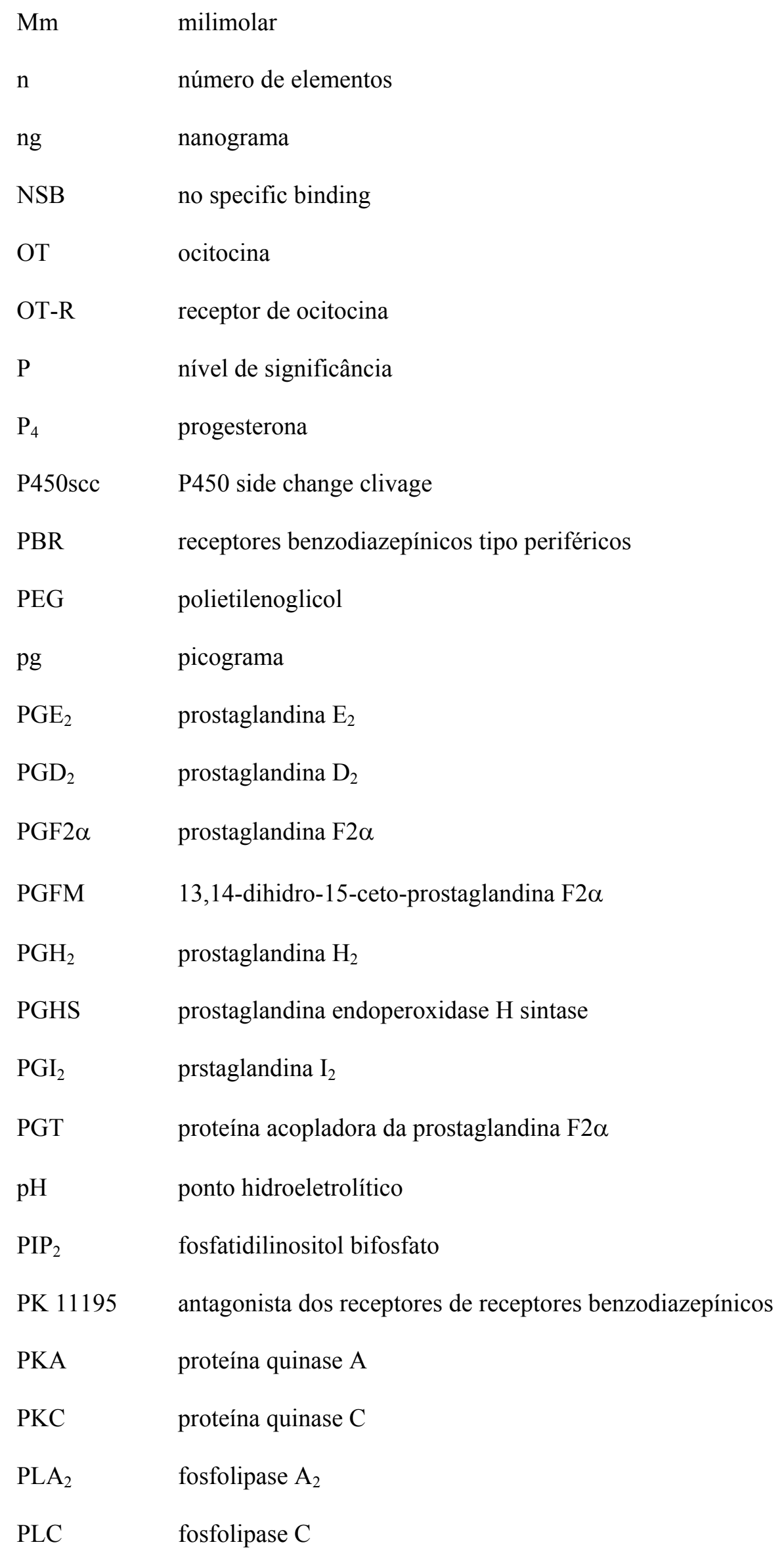




\begin{tabular}{ll} 
RNAm & ácido ribonucléico mensageiro \\
rpm & rotações por minuto \\
SLC & células luteais pequenas \\
StAR & steroidogenic acute regulatory protein \\
TC & total count \\
TNF $\alpha$ & fator de necrose tumoral $\alpha$ \\
UI & unidade(s) internacional (is) \\
$\mu \mathrm{g}$ & micrograma \\
$\mu \mathrm{L}$ & microlitro \\
$\mu \mathrm{m}$ & micrometro \\
$\mathrm{Vi}$ & volume inicial \\
$\mathrm{x}$ & por \\
\hline $3 \beta-\mathrm{HSD}$ & 3 beta hidroxiesteróide desidrogenase \\
$\%$ & por cento \\
$<$ & menor \\
$\leq$ & menor ou igual \\
$>$ & maior \\
&
\end{tabular}




\section{SUMÁRIO}

1. INTRODUÇÃ

\section{REVISÃO DE LITERATURA}

2.1 CICLO ESTRAL, FORMAÇÃO DO CORPO LÚTEO E FUNÇÃO LUTEAL.......................................................

2.2 MECANISMOS GERAIS ENVOLVIDOS NA LUTEÓLISE.......................................................................... 37

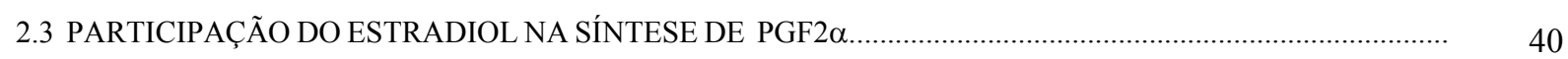

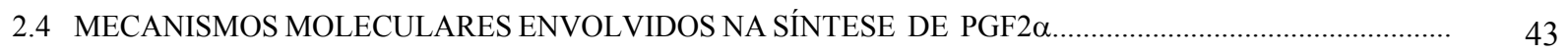

2.5 POSSÍVEIS MECANISMOS MOLECULARES DE ATUAÇÃO DO

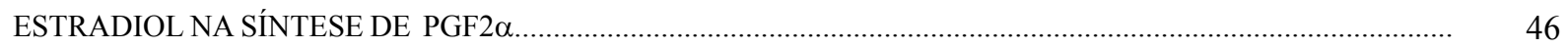

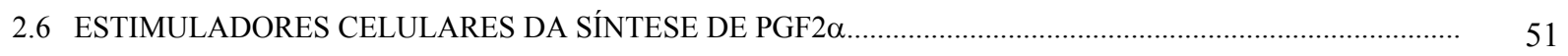

2.7 MODELO EXPERIMENTAL DE CULTIVO COM CÉLULAS

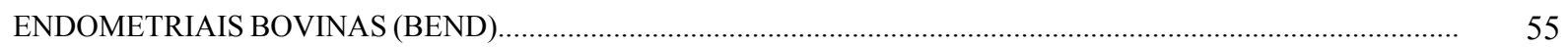

\section{OBJETIVOS}

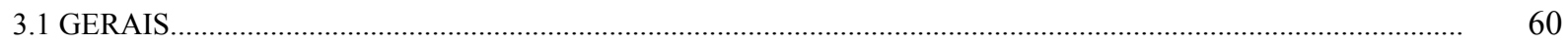

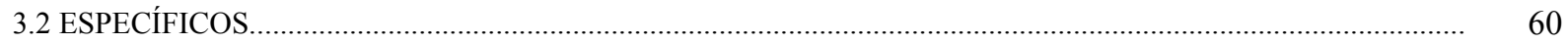

4. EXPERIMENTO 1: PRODUÇÃO DE PGFM EM RESPOSTA A ADMINISTRAÇÃO DE ESTRADIOL ENTRE OS DIAS 13 E 19 DO CICLO ESTRAL

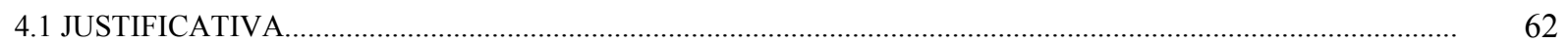

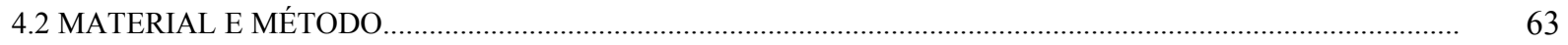

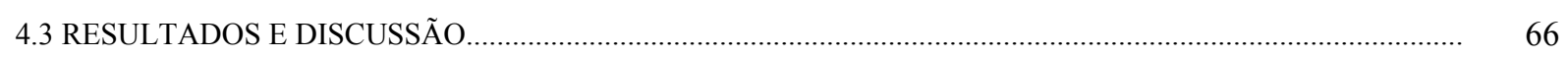

4.4 CONCLUSÕES

5. EXPERIMENTO 2: EFEITOS DO ESTRADIOL IN VIVO NA PRODUÇÃO DE PGF2 $\alpha$ INDUZIDA POR ESTIMULADORES DA SÍNTESE DE PGF2 $\alpha$ EM EXPLANTES ENDOMETRIAIS

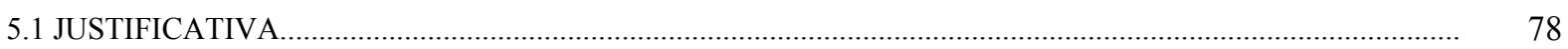

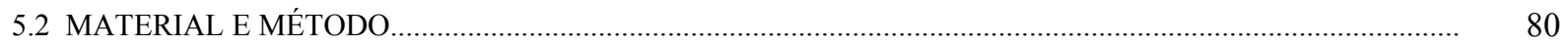

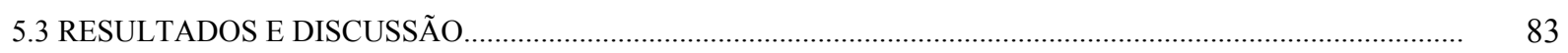

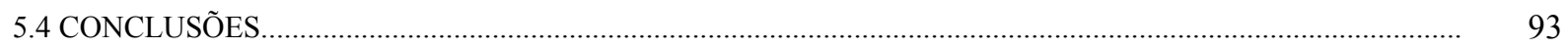


6. EXPERIMENTO 3: SÍNTESE DE PGF2 $\alpha$ EM CÉLULAS ENDOMETRIAIS BOVINAS TRATADAS COM IONÓFORO DE CÁLCIO

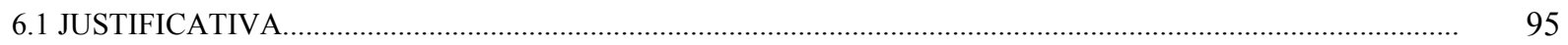

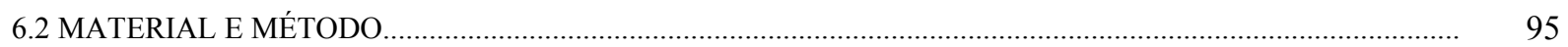

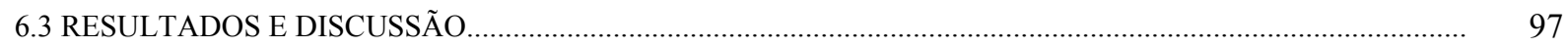

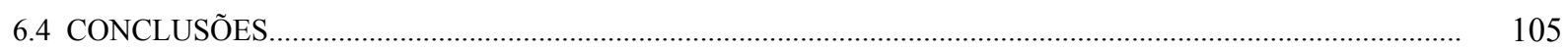

7. EXPERIMENTO 4: SÍNTESE DE PGF2 $\alpha$ EM CÉLULAS ENDOMETRIAIS BOVINAS TRATADAS COM IONÓFORO DE CÁLCIO E ESTRADIOL

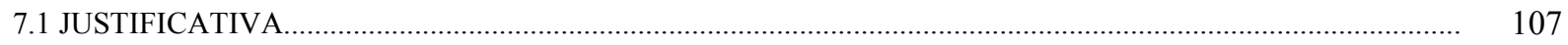

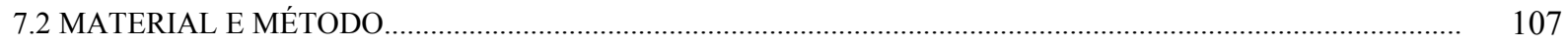

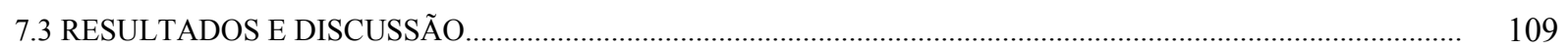

7.4 CONCLUSÕES

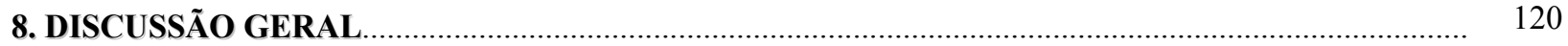

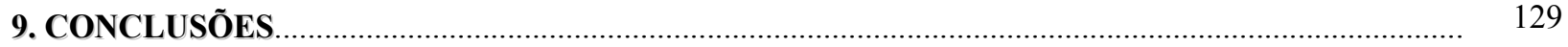

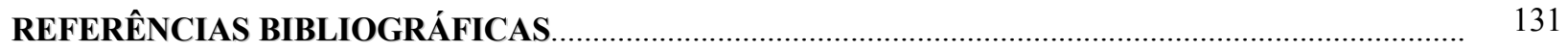

ANEXOS 
1. INTRODUÇÃO

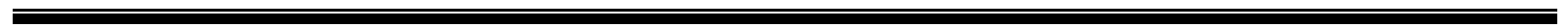




\section{INTRODUÇÃO}

Estudos e descobertas relacionadas aos processos reprodutivos tiveram seus primórdios com os gregos, que já se preocupavam com o mistério da concepção, influenciados pelo contato com civilizações do Oriente, nos tempos de Alexandre, o Grande. O primeiro tratado científico sobre reprodução, "A Geração dos Animais" de Aristóteles, data desta época. Somente 2.000 anos depois, Francis Marshall escreve "Fisiologia da Reprodução", publicado em 1910 na Inglaterra. No século XX, o desejo do homem em controlar os processos reprodutivos colaborou com grandes avanços no conhecimento da fisiologia da reprodução.

No início dos anos 20, com a descoberta da atividade do estradiol no fluído folicular, um grande número de estudos foi realizado culminando com a publicação do clássico relacionado à endocrinologia da reprodução "Sex and Internal Secretions", em 1932. Entre 1926 e 1936, o ritmo de descobertas na área reprodutiva, atingiu seu ponto máximo, ritmo este que talvez até hoje não tenha sido superado. Durante tal período revelou-se um aspecto muito importante e inesperado para a época: o padrão de secreção cíclico dos hormônios.

Durante a década passada, estudos envolvendo receptores para esteróides acrescentaram muito ao entendimento na área de fisiologia da reprodução, quando ilustraram que a formação do complexo hormônio-receptor e sua ação sobre a expressão gênica estão envolvidos em uma série de fenômenos fisiológicos. Atualmente, a endocrinologia molecular permite que genes cuja expressão esteja sob o controle endócrino, possam ser manipulados. Assim, pesquisas na área de reprodução animal têm determinado descobertas importantes, e dentre elas, muitas geram a expectativa de melhoria na eficiência reprodutiva das fêmeas bovinas. 
Atualmente a pecuária brasileira é uma das mais modernas do mundo. $\mathrm{O}$ alto padrão de sanidade e qualidade dos produtos de origem animal elevou as exportações do complexo de carne a US\$ 4,1 bilhões em 2003, contribuindo com um aumento de $31 \%$ comparado ao ano anterior. Em dez anos, o país dobrou o faturamento com as vendas externas de produtos agropecuários e teve um crescimento superior a $100 \%$ no saldo comercial. O Brasil conseguiu no último ano um resultado além das previsões mais otimistas. Tais resultados levaram a Conferência das Nações Unidas para o Comércio e Desenvolvimento a prever que o Brasil será o maior produtor mundial de alimentos na próxima década.

O Brasil possui o maior rebanho bovino comercial do mundo, constituído por 183 milhões de cabeças sendo mais de $83 \%$ provenientes de áreas livres da febre aftosa. O país também é considerado pelo Comitê Veterinário da União Européia como "área de risco desprezível" para a ocorrência da Encefalopatia Espongiforme Bovina, chamada de "Mal da Vaca Louca", doença que dizimou rebanhos na Europa e recentemente atingiu o continente americano. Tais fatores contribuíram para que as exportações de carne bovina in natura e industrializada crescessem $40 \%$ em 2003, totalizando 1,4 milhão de toneladas embarcadas principalmente para o Chile, Países Baixos, Egito, Reino Unido, Itália, Arábia Saudita e Alemanha. Assim, o Brasil assume a posição de líder mundial nas exportações de carne, superando a Austrália. Tal desempenho da pecuária nacional está agregado à melhoria genética dos rebanhos associada à intensificação dos conhecimentos e da prática de técnicas relativas aos manejos nutricionais, sanitários e reprodutivos do rebanho bovino brasileiro.

Na criação de bovinos de corte a produtividade está diretamente relacionada à eficiência reprodutiva das fêmeas, que devem apresentar um adequado intervalo entre partos, ao redor de 12 meses. Em propriedades especializadas na produção de novilhos para o abate, as baixas taxas de natalidade e as altas taxas de mortalidade dos bezerros certamente representam os principais fatores na composição dos custos. No Brasil, infelizmente, há baixa 
taxa de natalidade e alta taxa de mortalidade que, associadas, caracterizam longos intervalos entre partos. Certamente, mudanças nesta situação representam um grande desafio para a pecuária brasileira nos próximos anos. Para a cadeia produtiva de carne bovina brasileira, torna-se necessário conceber um conjunto de ações que viabilizem ao máximo tal atividade, pois as oportunidades de crescimento são ímpares nesta década.

A mortalidade embrionária associada à falha na manutenção do corpo lúteo aumenta os intervalos entre os partos (HANK, 1979). Diskin e Sreenan (1980) relataram que as falhas de fertilização até oito dias pós-inseminação são responsáveis por $10 \%$ dos casos de fracasso reprodutivo, enquanto as mortes embrionárias entre os dias 8 e 16 pós-inseminação contribuem com mais de $30 \%$ dos referidos casos. Isso justifica relatos de taxas de nascimento após única inseminação de 50 a 55\% para novilhas (SREENAN; MULVEHILL, 1975; ROCHE; PRENDERVILLE; DAVIS, 1777), de 52\% a 57\% para vacas selecionadas para a produção leiteira (MAWHINNEY; ROCHE, 1978) e de 53\% para vacas especializadas na produção de carne (ROCHE; PRENDERVILLE; DAVIS, 1777).

A ocorrência da luteólise, entre os dias 15 e 19 do ciclo estral é de fundamental importância para determinar o fim da fase progestacional, o desenvolvimento de um folículo ovulatório e o estro. Entretanto, durante este período, na ocorrência de uma prenhez, o concepto (embrião e membranas associadas) deve tornar-se capaz de enviar sinais antiluteolíticos apropriados ao endométrio e este responder a tais sinais, inibindo a síntese de PGF2 $\alpha$. Freqüentemente, esse evento fisiológico não é bem sucedido, resultando na ocorrência da luteólise, na mortalidade embrionária e em perdas representativas na pecuária.

É de amplo conhecimento que pulsos de prostaglandina F2 $\alpha$ (PGF2 $\alpha$ ) produzidos pelo endométrio entre os $15^{\circ}$ e $19^{\circ}$ dias do ciclo estral, determinam a luteólise. Sabe-se ainda que a estimulação da síntese de PGF2 $\alpha$ envolve fatores endócrinos como estradiol ( $\left.E_{2}\right)$, a ocitocina (OT), a progesterona $\left(\mathrm{P}_{4}\right)$ e o hormônio luteinizante (LH). O papel do $\mathrm{E}_{2}$ neste contexto foi 
pouco estudado. Contudo, sabe-se que a supressão do $E_{2}$, através da irradiação ou cauterização de folículos retarda a luteólise (HUGHES et al., 1987). A administração de $\mathrm{E}_{2}$ em vacas cíclicas estimula a luteólise e promove o estro (THATCHER et al., 1986). Vacas prenhes apresentam diminuição do $\mathrm{E}_{2}$ circulante (PRITCHARD; SCHRICK; INSKEEP, 1994), provavelmente em função de uma redução no desenvolvimento folicular e na produção de $\mathrm{E}_{2}$ pelo folículo (THATCHER et al., 1991). Além disso, a administração de $\mathrm{E}_{2}$ em vacas no $18^{\circ}$ dia da prenhez estimula apenas de maneira modesta a produção de PGF2 $\alpha$ (THATCHER et al., 1991) sugerindo que provavelmente a presença do embrião atenua os efeitos do $E_{2}$. Diante destas informações fica claro que o $\mathrm{E}_{2}$ desempenha um papel crucial na luteólise e que, para a manutenção da prenhez, o embrião diminui os efeitos do $E_{2}$ sobre a produção de PGF2 $\alpha$.

A síntese de PGF2 $\alpha$ no endométrio de fêmeas bovinas resulta de uma complexa cascata de eventos intracelulares que ocorrem de maneira altamente coordenada. Tais eventos envolvem a ativação seqüencial de várias proteínas como a proteína acopladora do GTP, da fosfolipase C (PLC), da proteína quinase-C (PKC), da fosfolipase $\mathrm{A}_{2}\left(\mathrm{PLA}_{2}\right)$ e da ciclooxigenase 2 (COX-2). É possível que o estradiol estimule a síntese e/ou a atividade de moléculas envolvidas na cascata geradora de PGF2 $\alpha$, como enzimas e receptores para outros ligantes. Dessa forma, torna-se relevante à necessidade de ampliar os conhecimentos dos mecanismos pelos quais o estradiol promove a síntese de PGF2 $\alpha$ e a luteólise.

Assim, o objetivo geral do presente estudo foi investigar os mecanismos endócrinos e moleculares estimulados pelo estradiol durante a luteólise em fêmeas bovinas. Acredita-se que a aquisição de tais conhecimentos poderá contribuir para a elaboração de estratégias que facilitem o bloqueio da luteólise e o desenvolvimento do concepto, visando melhorar a eficiência reprodutiva em programas de acasalamento e de transferência de embriões, 
contribuindo com um aumento na eficiência reprodutiva das fêmeas e em um adequado intervalo entre partos. 


\section{REVISÃO DE LITERATURA}

A revisão abordará inicialmente dados da literatura que descrevem os mecanismos celulares, endócrinos e moleculares envolvidos na formação do corpo lúteo (CL), na função luteal e na luteólise durante o ciclo estral de fêmeas bovinas. A seguir serão apresentados dados referentes aos efeitos e possíveis mecanismos de ação do $\mathrm{E}_{2}$ e do cálcio na síntese de PGF2 $\alpha$ endometrial. Por fim, serão enfatizados dados da literatura que se referem ao cultivo de células BEND como modelo biológico experimental.

\subsection{CICLO ESTRAL, FORMAÇÃO DO CORPO LÚTEO E FUNÇÃO LUTEAL}

O ciclo estral compreende um conjunto de eventos fisiológicos coordenados que ocorre no período entre dois estros. Em fêmeas bovinas, a duração do ciclo estral varia de 17 a 25 dias (SIROIS; FORTUNE, 1988; LAMOTHE-ZAVALETA; FREDRIKSSON; KINDHAL, 1991), sendo relatado em uma pequena porcentagem de animais ciclos com uma duração maior que 25 dias (WISHART, 1972).

Durante o ciclo estral o desenvolvimento folicular avaliado por ultra-sonografia, caracterizou-se pela presença de duas ou três ondas de crescimento folicular na maioria das fêmeas (SIROIS; FORTUNE, 1988; GINTHER; KNOPF; KASTELIC, 1989) e eventualmente a ocorrência de uma, quatro ou cinco ondas foliculares (SIROIS; FORTUNE, 1988; RHODES; DE'ATH; ENTWISTLE，1995; ZEITOUN; RODRIGUEZ; RANDEL, 1996; ALVAREZ et al., 2000; VIANA et al., 2000). Também verificou-se a presença de um de um corpo lúteo (CL) funcional entre os dias 4 e 17 do ciclo estral (MURPHY et al., 1991).

O desenvolvimento folicular é um processo dinâmico e contínuo, onde a cada onda de crescimento, um "pool" de folículos é recrutado e inicia o crescimento, sob influência do 
hormônio folículo estimulante (FSH), até que um deles se torne o folículo dominante. $\mathrm{O}$ folículo dominante é caracterizado pela maior capacidade de produzir $17 \beta$-estradiol em relação aos demais folículos recrutados. Estabelecida a dominância folicular, o folículo dominante continua o seu desenvolvimento enquanto os demais folículos da mesma onda entram em atresia (BAO; GARVERICK, 1998).

Durante o crescimento folicular a síntese de $\mathrm{E}_{2}$ resulta de um trabalho coordenado entre as células foliculares da teca e da granulosa. $\mathrm{O}$ modelo de esteroidogênese mais aceito foi proposto por Fortune e Quirk, em 1988. Nesse modelo a ligação do LH a receptores existentes nas células da teca estimula a atividade da enzima P450 17 $\alpha$-hidroxilase, que atua na conversão da pregnenolona em androstenediona, sendo as células da granulosa incapazes de realizar tal conversão. A adrostenediona é metabolizada em $\mathrm{E}_{2}$ pela enzima P450aromatase, enzima presente exclusivamente nas células da granulosa.

A presença de um folículo pré-ovulatório e de altas concentrações plasmáticas de $\mathrm{E}_{2}$, são determinantes para o desencadeamento da expressão do comportamento de estro, do pico pré-ovulatório de LH e da ovulação. Na ovulação ocorre a ruptura da membrana folicular e a expulsão do oócito. Imediatamente após a ovulação a parede do folículo ovulado é colapsada e a cavidade invadida por linfa e sangue provenientes dos capilares. Esse conjunto de componentes juntamente com as células remanescentes do folículo ovulado formará inicialmente uma estrutura denominada de corpo hemorrágico (DIAZ et al., 2002).

O corpo hemorrágico reorganiza-se para formar o CL sob influência de fatores angiogênicos e mitogênicos, como: fator de crescimento dos fibroblastos (GOSPODAROWICZ; CHENG; LUI, 1985; SCHAMS; BERISHA, 2004), fator de crescimento I semelhante à insulina (SUH; HUNT; SPENCER, 1992; SCHAMS; BERISHA, 2004), fator de crescimento semelhante a heparina (GRAZUL-BILSKA; REDMER; KILLILEA, 1992) e fator de crescimento endotelial vascular (REDMER; REYNOLDS, 
1996), dentre outros. Em fêmeas bovinas o crescimento do CL é extremamente rápido e resulta do aumento no número e tamanho das células luteais originadas das células granulosas e da teca remanescentes do folículo ovulado, além do crescimento das células endoteliais e dos fibroblastos (FIELDS; FIELDS, 1996). A velocidade de crescimento do tecido luteal é semelhante a de um tecido tumoral (JABLONKA-SHARIFF; GRASUL-BILSKA; REMENDER, 1993).

$\mathrm{Na}$ maioria dos mamíferos as células granulosas remanescentes originam as células luteais grandes (LLC; Large Luteal Cells) e as da teca as células luteais pequenas (SLC; Small Luteal Cells). As SLC se caracterizam por medirem menos que $20 \mu \mathrm{m}$, liberarem baixas concentrações de $\mathrm{P}_{4}$ e serem responsivas ao LH. As LLC medem de 20-30 $\mu$ m, produzem altas quantidades de $\mathrm{P}_{4}$ e não serem responsivas a estimulação com LH (FITZ et al., 1984; KOSS; HANSEL, 1981). Um estudo avaliou a porcentagem das LLC e SLC entre os dias 3-5, 10-12, $15-18,19-20$ do ciclo estral e determinou porcentagens de $1,6 \%, 5,1 \%, 4,5 \%$ e $2,2 \%$ para as LLC e de $98,3 \%, 95 \%, 95,4 \%$ e $97,7 \%$ para as SLC, respectivamente. Observou-se que as LLC mesmo presentes em pequena porcentagem ocupam aproximadamente $70 \%$ da área total do CL e secretam mais de $85 \%$ da $\mathrm{P}_{4}$ produzida pelo CL (HANSEL; ALILA; DOWD, 1987). Evidenciou-se que algumas células luteais pequenas são transformadas em células luteais grandes em corpos lúteos maduros (ALILA; HANSEL, 1984). A reorganização celular, objetivando o preparo das células luteais para a síntese crescente de $\mathrm{P}_{4}$ ao longo do ciclo estral, também foi caracterizada por uma diminuição na expressão das enzimas que convertem $\mathrm{P}_{4}$ em 17ß-estradiol (P450 17 $\alpha$-hidroxilase e P450 aromatase), por um aumento na expressão das enzimas necessárias para a conversão do colesterol em $\mathrm{P}_{4}(\mathrm{P} 450 \mathrm{scc}$ e a $3 \beta$-HSD) e aumento das proteínas transportadoras de colesterol para o interior da membrana mitocondrial. (FRASER; ABBOTT; LAIRD, 1986). 
O substrato para a produção de $\mathrm{P}_{4}$ é o colesterol, sintetizado principalmente no fígado (KRISANS, 1996) e transportado na forma de lipoproteínas para todos os tecidos esteroidogênicos. As lipoproteínas podem ser de alta (HDL) ou de baixa densidade (LDL) e constituem as fontes mais comuns de disponibilidade de colesterol para a produção dos hormônios esteróides no CL. A captura da LDL pelas células esteroidogênicas luteais ocorre por endocitose, uma via bastante eficiente que contribui para a captura de grande quantidade de colesterol, pois cada molécula de LDL disponibiliza aproximadamente 2.500 moléculas de colesterol. O HDL extracelular encontra-se conjugado a proteínas do plasma, tal complexo se liga à membrana celular promovendo o transporte do HDL para dentro da célula. O colesterol disponível no citosol da célula é utilizado como substrato para a esteroidogênese (BROWN; GOLDSTEIN, 1986). O colesterol é transportado do citosol para a membrana mitocondrial por proteínas específicas. Na membrana mitocondrial interna o colesterol interage com a enzima P450scc transformando-se em pregnenolona. A pregnenolona é transportada para o retículo endoplasmático liso e por ação da enzima $3 \beta$-HSD é convertida em $\mathrm{P}_{4}$ (NISWENDER, 2002).

Basicamente três proteínas realizam o transporte do colesterol para a membrana mitocondrial, sendo elas: a proteína de regulação aguda da esteroidôgenese (StAR; “Steroidogenic Acute Regularoty Protein”), o receptor benzodiazepínico tipo periférico (PBR) e a endozepina, uma ligante natural do PBR. Niswender (2002) propõe que a proteína StAR seria o principal elemento transportador de colesterol. A StAR se ligaria ao colesterol no citoplasma e o transportaria para a membrana mitocondrial externa, quando faria a transferência da molécula de colesterol ao PBR, que o transportaria para a membrana mitocondrial interna. A endozepina mudaria a conformação do PBR capacitando-o para o transporte do colesterol ou facilitando a interação da StAR com o PBR na permuta do colesterol. 
O transporte do colesterol para a membrana mitocondrial é dependente da fosforilação da proteína StAR. A StAR possui dois sítios de fosforilação, um fosforilado pela PKA e outro pela PKC. A ligação do LH a receptores específicos nas SLC estimula a fosforilação da StAR e do PBR pela PKA, favorecendo o aumento no transporte de colesterol. Assim, o LH parece modular a síntese de $\mathrm{P}_{4}$ não pelo aumento da expressão das enzimas esteroidogênicas mas por facilitar a disponibilidade e o transporte de colesterol do citoplasma para a membrana mitocondrial. Durante a luteólise, a prostaglandina F2 $\alpha(\mathrm{PGF} 2 \alpha)$ exerce um efeito contrário ao LH na célula luteal, pois estimula a fosforilação da StAR pela PKC, contribuindo para uma redução no transporte do colesterol para a membrana mitocondrial. O efeito da PGF2 $\alpha$ ainda inclui uma diminuição na concentração de RNAm para o receptor de LH, StAR e 3 $\beta$-HSD (NISWENDER, 2002).

Um estudo avaliou os fatores envolvidos na superior capacidade das LLC em sintetizarem $\mathrm{P}_{4}$ quando comparadas as SLC. Em tal estudo, as SLC e LLC foram tratadas com um agonista dos receptores de PBR (PK11195). Verificou-se que as concentrações de $\mathrm{P}_{4}$ no meio de cultivo das SLC tratadas com o agonista de PBR foi aumentada em seis vezes quando comparadas ao grupo controle. Assim, sugeriu-se a menor capacidade de produção de $\mathrm{P}_{4}$ das SLC quando comparadas as LLC poderia ser associada a menor concentração de PBR nas SLC. No mesmo estudo, verificou-se que as LLC apresentavam em média uma maior porcentagem de proteína StAR (34\%) e de endozepina (244\%) comparadas as SLC. Tais resultados sugerem que as LLC conteriam uma maior quantidade das proteínas requeridas para o transporte de colesterol, conferindo as LLC uma maior capacidade na síntese de $\mathrm{P}_{4}$ (FITZ et al., 1984).

Ao longo da fase luteal o CL aumenta em tamanho e capacidade de liberar $\mathrm{P}_{4}$. Tal capacidade foi associada ao aumento nas concentrações de RNAm das proteínas que participam da produção de $\mathrm{P}_{4}$, incluindo receptores para HDL, LDL, LH, GH, fatores de 
crescimento, StAR e enzimas esteroidogênicas (P450scc e 3 $\beta$-HSD), dentre outras. A concentração de tais componentes celulares definem os diferentes padrões da síntese de $\mathrm{P}_{4}$ pelo CL ao longo do ciclo estral (NISWENDER; JUENGEL; SILVA, 2000).

Em bovinos a duração do ciclo estral pode ser determinada pela presença do CL (BINELLI et al., 2000). Na maioria das fêmeas bovinas o CL está funcionalmente presente do dia 4 ao dia 17 do ciclo estral. Caso não ocorra a fertilização, torna-se necessária a regressão funcional do CL, processo denominado de luteólise. Tal processo fisiológico determina um declínio nas concentrações plasmáticas de $\mathrm{P}_{4}$, possibilitando um aumento da freqüência dos pulsos de LH e das concentrações de FSH nos últimos dias do ciclo estral. Em vacas vazias, a luteólise possibilita um padrão na secreção de gonadotrofinas imprescindível para que ocorra a ovulação e se inicie um novo ciclo estral (HAFEZ, 1993).

Em geral, as ações da $\mathrm{P}_{4}$ no trato reprodutivo estão relacionadas à preparação do mesmo para o desenvolvimento do concepto. No endométrio, a $\mathrm{P}_{4}$ induz a diferenciação das células do estroma, estimula a secreção glandular, promove o acúmulo de vacúolos basais no epitélio glandular (MASLAR; POWERS-CRADDOCK; ANSBACHER, 1986), altera o padrão de secreção das proteínas das células endometriais e induz ao relaxamento do miométrio (NISWENDER; JUENGEL; SILVA, 2000). O relaxamento induzido no miométrio pela $\mathrm{P}_{4}$ é determinado por um decréscimo na captação de cálcio extracelular, íon requerido para a contração das células miometriais (BATRA, 1986). A $\mathrm{P}_{4}$ ainda promove uma “dowregulation” na expressão dos genes que regulam os canais dependentes de cálcio, dificultando a entrada de cálcio na célula (TEZUKA; ALI; CHWALISZ, 1995). A ausência na contratilidade do miométrio e o desenvolvimento glandular do endométrio, promovidos pela $\mathrm{P}_{4}$, são condições essenciais para o desenvolvimento do concepto (embrião e membranas extra-embrionárias). 


\subsection{MECANISMOS GERAIS ENVOLVIDOS NA LUTEÓLISE}

O ciclo estral de fêmeas bovinas é mediado por um conjunto de mecanismos neuroendócrinos. A luteólise constitui um desses mecanismos e assume extrema importância na reprodução de fêmeas bovinas, determinando, na ausência de uma gestação, a ocorrência de estro e uma nova possibilidade de concepção. A inibição da luteólise é requerida para a manutenção da gestação nessa espécie.

Em fêmeas bovinas, é de amplo conhecimento que a PGF2 $\alpha$ é o principal agente luteolítico e tem como funções promover a luteólise (MEIDAN; MILVAE; WEISS, 1999; CARAMBULA et al., 2002) determinando o final da fase luteínica (DAVIS; COLLIER; McNAMARA, 1988; CHEN; GETSIOS; MAcCALMAN, 1998). O bloqueio da síntese de $\mathrm{P}_{4}$ resulta da interação da PGF2 $\alpha$ com seus receptores localizados nas células luteais esteroidogênicas (CHEN et al., 1998; MAMLUCK et al., 1998; OLSON; ANDERSON; WILTBANK, 2001; ANDERSON; WU; TSAI, 2001; SCHAMS; BERISHA, 2004).

Em fêmeas bovinas um "período crítico" é determinado quando o estado fisiológico reprodutivo da fêmea deve ser definido para a manutenção do CL e da prenhez ou para o desencadeamento da luteólise e do estro. O período crítico ocorre 15 a 19 dias após a ovulação. A luteólise é desencadeada pela ocorrência de cinco a oito pulsos de PGF2 $\alpha$ liberados pelo endométrio durante um período de 2 a 3 dias (NANCARROW; BUCKMASTER; CHAMELEY, 1973; THORBURN; COX; CURRIE, 1973; KINDHAL et al., 1976; FREDRICKSON; KINDHAL; EDQVIST, 1984). A natureza pulsátil de produção de PGF2 $\alpha$ endometrial é imprescindível para a ocorrência da luteólise (DANETDESNOYERS et al., 1995; OKUDA; MIYAMOTO; SKARZINSKY, 2002).

A concentração basal de PGFM em vacas durante a fase luteínica varia de 10 a $100 \mathrm{pg} / \mathrm{mL}$. No momento da luteólise, PGFM é produzida em picos que duram de 2 a 5 horas, 
em intervalos que variam de 2 a 30 horas, com concentrações plasmáticas de 150 a $500 \mathrm{pg} / \mathrm{mL}$ (BASU; KINDAHL, 1987b; KOTWICA et al., 1998). Em ruminantes aproximadamente 98\% da PGF2 $\alpha$ produzida pelo útero é metabolizada em 13,14-diidro-15-ceto-prostaglandina F2 $\alpha$ (PGFM) na primeira passagem pelos pulmões. Dessa forma, a produção de PGF2 $\alpha$ é mensurada in vivo através do seu principal metabólito, a PGFM. A PGFM possui uma meiavida na circulação periférica de aproximadamente 8 minutos (PIPER; VANE; WILLIE, 1970). Em vacas e ovelhas, uma interessante particularidade anatômica foi desenvolvida para que a PGF2 $\alpha$ pudesse alcançar o CL antes da sua metabolização. Nessas espeçies a artéria ovariana fica enovelada à superfície da veia útero-ovariana que transversalmente é extremamente tortuosa, favorecendo o transporte de muitas substâncias da veia útero ovariana para a artéria ovariana. Foi postulado que a PGF2 $\alpha$ produzida no corno uterino passa através da veia utero ovariana para a artéria ovariana chegando ao CL ipsolateral ao corno uterino secretor de PGF2 $\alpha$. Esse percurso destinado ao transporte da PGF2 $\alpha$, que isenta a passagem pela circulação periférica, impede que PGF2 $\alpha$ seja imediatamente metabolizada pelos pulmões (PIPER; VANE; WILLIE, 1970). Hixon e Hansel (1974) verificaram que a infusão de PGF2 $\alpha$ na cavidade uterina causou uma persistente elevação das concentrações de PGF2 $\alpha$ no plasma da artéria ovariana, entretanto, o mesmo não foi observado no plasma da artéria carótida, sustentando a hipótese de que a PGF2 $\alpha$ produzida no endométrio chega ao CL através de um mecanismo de contra-corrente.

Em fêmeas bovinas foi reportada a existência de uma proteína transportadora de PGF2 $\alpha$ (PGT). Tal proteína atua mediando o transporte da PGF2 $\alpha$ pelas vias vasculares do endométrio para o ovário. O RNAm para a PGT foi expresso no endométrio, miométrio e plexo útero-ovárico durante o ciclo estral. No endométrio o grau de expressão do RNAm para a PGT foi baixo entre os dias 1 e 9 , moderado entre os dias 10 a 15 e 19 a 21 e máximo entre os dias 16 e 18 do ciclo estral, período que coincide com a luteólise (BANU et al., 2003). 
Foi observado em fêmeas bovinas que o número de receptores para PGF2 $\alpha$ no CL aumenta ao longo da fase luteal. A administração exógena de PGF2 $\alpha$, entre os dias 5 e 15 do ciclo estral, desencadeia uma seqüência irreversível de eventos no CL de maneira muito similar à luteólise espontânea. Um único tipo de receptor para PGF2 $\alpha$ foi identificado, entretanto, tais receptores variaram quanto à afinidade de ligação à PGF2 $\alpha$. Foram caracterizados receptores de alta e baixa capacidade de ligação a PGF2 $\alpha$. Nessa espécie, o RNAm para os receptores de PGF2 $\alpha$ foi identificado nas SLC, LLC e células endoteliais (MAMLUCK et al., 1998). Em ovinos, as SLC apresentam receptores com baixa afinidade para a PGF2 $\alpha$ enquanto as LLC possuem receptores de alta e baixa afinidade pela PGF2 $\alpha$ (JUENGEL; MEBERG; TURZILLO, 1995; JUENGEL; NETT; TANDESKI, 1995).

A PGF2 $\alpha$ se liga a receptores específicos na membrana das células luteais esteroidogênicas e estimulam a atividade da PKC, que atua de diversas maneiras: diminuindo a captação e o transporte de colesterol para o citoplasma e para a mitocôndria, mediando a ação anti-esteroidogênica da PGF2 $\alpha$ nas LLC (ZAMBETTI; LEVINE, 1993), determinando a falência da produção de $\mathrm{P}_{4}$ pelo CL acompanhada por uma “dowregulation" nos receptores de LH (NISWENDER, 2002) e possivelmente aumentando a expressão e ativação das proteínas envolvidas no processo de morte celular (SCHWARTZMAN; CIDLOWSKI, 1993).

Nas células endoteliais que constituem o sistema vascular do CL a PGF2 $\alpha$ estimula a síntese de RNAm e a secreção de endotelina 1 (ET-1). A ET-1 é um das mais potentes substâncias vasoconstritoras. Em vacas, essa característica é mais evidente entre os dias 17 e 21 do ciclo estral, sendo cerca de 30 vezes maior que nos dias 5 e 6 do ciclo (GIRSH; MILVAE; WANG, 1996; GIRSH; WANG; MAMLUCK, 1996).

No modelo descrito por Meidan, Milvae e Weiss (1999) a PGF2 $\alpha$ se liga a receptores nas LLC e promove uma drástica redução na produção de $\mathrm{P}_{4}$ e um aumento na secreção de OT, eventos que aumentam a expressão de ET-1. A PGF2 $\alpha$ liga-se aos receptores presentes 
nas células endoteliais e estimula a síntese de ET-1. A PGF2 $\alpha$ e ET-1 induzem uma vasoconstrição nos vasos que irrigam o CL e subseqüente hipóxia, condições que amplificam a secreção de ET-1. A ET-1 promove a morte das células vasculares e esteroidôgenicas. Esse processo é acompanhado por um influxo de monócitos, macrófagos e pela secreção local de citocinas inflamatórias, dentre elas o fator de necrose tumoral $\alpha(\mathrm{TNF} \alpha)$.

Existem evidências da participação do sistema imune na luteólise. No modelo da regressão estrutural do CL em ruminantes, segundo Meidan; Milvae e Weiss (1999), as células endoteliais apresentam receptores para a PGF2 $\alpha$ e quando estimuladas pela PGF2 $\alpha$ promovem o recrutamento e a migração de monócitos para o CL. Esta migração também é induzida pela proteína monoquimioatrativa tipo 1 (MCP-1). A migração e a maturação dos macrófagos é acompanhada pela ativação do $\mathrm{TNF} \alpha$ que ligado a seu receptor específico presente na grande maioria das células que constituem o CL desencadeia nessas células a apoptose. A ocorrência de apoptose nas células que constituem o CL caracteriza-se inicialmente por fragmentação nuclear, degeneração da cromatina, diminuição da célula e fragmentação de membranas, que são posteriormente fagocitadas por macrófagos.

\subsection{PARTICIPAÇÃO DO ESRADIOL NA SÍNTESE DE PGF2 $\alpha$}

Em fêmeas bovinas a participação da OT no controle da luteólise foi inicialmente reportada por Armstrong e Hansel (1959). Em ovinos, um mecanismo de "feedback" positivo estimulado pela OT parece promover a liberação pulsátil de PGF2 $\alpha$ pelo endométrio (McCRACKEN; SCHRAMM; OKULICZ, 1984). Segundo estes autores, a OT proveniente da neurohipófise estimula a produção de PGF2 $\alpha$ uterina e esta por sua vez, estimula a liberação de OT pelo CL, que atua estimulando ainda mais a liberação de PGF2 $\alpha$ endometrial, caracterizando um sistema de retroalimentação positiva. Neste modelo, a luteólise tem início 
devido ao aumento do número de receptores para OT no endométrio, induzido provavelmente pelo $\mathrm{E}_{2}$. De fato, demonstrou-se com uma série de estudos in vivo que o $\mathrm{E}_{2}$ é capaz de estimular a expressão dos receptores endometriais de OT (HIXON; FLINT, 1987; BEARD; LAMMING, 1994; SPENCER et al., 1995).

Até recentemente este mecanismo de desencadeamento da luteólise também era aceito para bovinos. Porém, em estudos utilizando o CAP-527 (um antagonista para receptor de OT) antes e durante o período da luteólise, a duração da fase luteínica e do ciclo estral não foi alterada em bovinos e suínos (KOTWICA et al., 1997; KOTWICA et al., 1999). Esses resultados evidenciam que a OT desempenharia um papel facilitador e não essencial no desencadeamento da luteólise. Acredita-se que a OT atue modulando a amplitude dos pulsos de PGF2 $\alpha$ durante a luteólise em bovinos (OKUDA; MIYAMOTO; SKARZINSKY, 2002). Visto que a OT não é imprescindível para a ocorrência da luteólise, muitos pesquisadores vêm focalizando o $\mathrm{E}_{2}$ como principal indutor da luteólise em bovinos.

$\mathrm{O} \mathrm{E}_{2}$ é sintetizado pelas células da granulosa de folículos antrais, especialmente em folículos dominantes pré-ovulatórios (DIELEMAN; BEVERS, 1987). Em bovinos, as concentrações plasmáticas de $\mathrm{E}_{2}$ caracterizam um padrão oscilatório ao longo do ciclo estral, em função das ondas de crescimento folicular (GINTHER; KNOPF; KASTELICK, 1989). Concentrações plasmáticas máximas de $\mathrm{E}_{2}$ são atingidas momentos antes da ovulação (ROCHE et al., 1998).

Em diversos estudos foi demonstrada a importância do $E_{2}$ na luteólise e na produção de PGF2 $\alpha$ pelo endométrio. Knickerbocker et al. (1986) constataram uma aguda elevação de PGF2 $\alpha$ na veia uterina de vacas tratadas com $E_{2}$. Thatcher et al. (1986) administraram $\mathrm{E}_{2}$ em vacas no $15^{\circ}$ dia do ciclo estral e observaram a ocorrência de luteólise seguida da menifestação de estro. Em outros estudos a administração de $E_{2}$ no meio da fase luteínica 
antecipou a luteólise em bovinos (GENGENBACH; HIXON; HANSEL, 1977; HANSEL; CONCANNON; LUKASZEWSKA, 1973).

A ablação de folículos ovarianos por irradiação ou cauterização, procedimentos que ocasionam uma supressão temporária do $\mathrm{E}_{2}$ circulante, retardou a luteólise em ruminantes (HUGHES et al., 1987; KARSH et al., 1970; VILLA-GODOY et al., 1981). Salfen et al. (1999) verificaram atraso na luteólise em vacas cujo desenvolvimento da segunda onda folicular foi inibido. $\mathrm{O} \mathrm{E}_{2}$ endógeno ou exógeno é capaz de induzir a produção de PGF2 $\alpha$ uterina (HANSEL; CONCANNON; LUKASZEWSKA, 1973) causando diminuição nas concentrações de $\mathrm{P}_{4}$ circulante e regressão do CL (AULETA; FLINT, 1988).

Para o estabelecimento e manutenção da prenhez, a luteólise precisa ser inibida, uma vez que a $\mathrm{P}_{4}$ produzida pelo CL é fundamental para a sobrevivência do embrião (THATCHER et al., 1986). Vacas prenhes apresentam diminuição do $E_{2}$ circulante (PRITCHARD; SCHRICK; INSKEEP, 1994), provavelmente em função da redução no desenvolvimento folicular e na produção de $E_{2}$ pelos folículos (THATCHER et al., 1991). Além disso, a administração de $\mathrm{E}_{2}$ no $18^{\circ}$ dia da prenhez, estimulou apenas de maneira modesta a produção de PGF2 $\alpha$ (THATCHER et al., 1991). Assim, sugere-se que a presença do embrião atenua os efeitos do $\mathrm{E}_{2}$.

$\mathrm{O}$ efeito do $\mathrm{E}_{2}$ na liberação de PGF2 $\alpha$ in vitro ainda não está claro. Em estudos realizados por Asselin et al. (1996) e Xiao et al. (1998) verificou-seque a adição de $\mathrm{E}_{2}$ ao meio de cultivo de explantes endometriais não estimulou a liberação de PGF2 $\alpha$. Entretanto, Mann (2001) verificou um aumento na síntese de PGF2 $\alpha$ em explantes endometriais bovinos cultivados com $E_{2}$. Em outro estudo, explantes endometriais de novilhas, entre os dias 11 e 17 do ciclo, tratados com $\mathrm{P}_{4}$ a produção de PGF2 $\alpha$ foi estimulada, entretanto, quando a $\mathrm{P}_{4}$ foi associada ao $\mathrm{E}_{2}$ esse efeito foi potencializado (SKARZYNSKI; BOGACKI; KOTWICA, 
1999). Efeito semelhante foi verificado em explantes endometriais de ovelhas ovariectomizadas (RAW; SILVIA; CURRY, 1995).

Sugere-se, a partir dos dados reportados na literatura, que o $E_{2}$ assume um papel fundamental na luteólise, entretanto, os mecanismos envolvidos na ação do $E_{2}$ na luteólise ainda não foram elucidados. A busca de maiores conhecimentos sobre os mecanismos endócrinos e moleculares pelos quais o $\mathrm{E}_{2}$ estimula a síntese de PGF2 $\alpha$ no endométrio constitui o objetivo principal da presente tese.

\subsection{MECANISMOS MOLECULARES ENVOLVIDOS NA SÍNTESE DE PGF2 $\alpha$}

As prostaglandinas são compostos eicosanóides bioativos derivados de ácidos graxos com 20 carbonos que por ações parácrinas e autócrinas, desempenham funções fisiológicas e patológicas em diversos órgãos e tecidos do organismo (BERGSTRON et al., 1964). Apesar da reconhecida importância do controle da síntese de PGF2 $\alpha$ na luteólise, pouco se sabe sobre os mecanismos pelos quais este controle é realizado. Hormônios como o $\mathrm{E}_{2}, \mathrm{P}_{4}$, OT (SILVIA et al., 1991) e LH (CANINO et al., 1999) parecem estar envolvidos na regulação deste complexo evento fisiológico.

A síntese de PGF2 $\alpha$ resulta de uma cascata de eventos intracelulares altamente coordenados, que envolve a ativação seqüencial de várias proteínas. Os substratos para a produção de prostaglandinas são os fosfolipídios araquidonilados, como a plasmenililcolina, fosfatidilcolina e alquilacil glicerolfosforilcolina (DIAZ et al., 2002). Um modelo celular da biossíntese de PGF2 $\alpha$ a partir do AA foi descrito por Burns et al. (1997). Nesse modelo, representado na Figura 1, em células epiteliais endometriais a OT se liga ao seu receptor e este associa-se à proteína G ativando a fosfolipase C (PLC). A PLC ao ser ativada cliva o fosfatidilinositol bifosfato $\left(\mathrm{PIP}_{2}\right)$ em inositol trifosfato $\left(\mathrm{IP}_{3}\right)$ e diacilglicerol (DAG). $\mathrm{O} \mathrm{IP}_{3}$ se 
liga a receptores específicos no retículo endoplasmático, promovendo a liberação de cálcio do interior do retículo endoplasmático para o citosol. O DAG ativa uma serina/treonina da proteína quinase $\mathrm{C}(\mathrm{PKC})$, também dependente de cálcio para sua ativação (ALBERTS et al., 1997). A PKC ativada, fosforila a fosfolipse $A_{2}\left(P_{L A}\right)$. $O$ aumento do cálcio no citosol induzido pelo $\mathrm{IP}_{3}$ age estimulando a atividade da $\mathrm{PLA}_{2}$, de fato, dependente de cálcio (CLARK, et al., 1991). A PLA 2 é uma enzima de $85 \mathrm{kDa}$ que cliva preferencialmente na posição sn-2 da fosfatidilcolina. liberando AA (GIJON; LESLIE, 1999). A seguir, o AA livre é convertido a prostaglandina $\mathrm{H}_{2}\left(\mathrm{PGH}_{2}\right)$ pela enzima prostaglandina endoperoxidase $\mathrm{H}$ sintase (PGHS) ou ciclooxigenase 2 (COX-2). Essa conversão geralmente é considerada uma etapa limitante na produção de prostaglandinas. Há duas isoformas de ciclooxigenase (COX) que catalizam a conversão do AA para $\mathrm{PGH}_{2}$ : a $\mathrm{COX}-1$ e a COX-2. A COX-1 é expressa constitutivamente (COHN et al., 1997), enquanto a COX-2 é expressa em vários tecidos do organismo (SIMON, 1999). É de amplo conhecimento que a COX-2 é a enzima responsável pela conversão do $\mathrm{AA}$ a $\mathrm{PGH}_{2}$ no endométrio. $\mathrm{A} \mathrm{PGH}_{2}$ é convertida à $\mathrm{PGF} 2 \alpha$ pela ação da PGF sintase (PGFS). A PGF2 $\alpha$ assim como as outras prostaglandinas não são armazenadas nas células, e sim liberadas imediatamente após sua síntese (OKUDA; MIYAMOTO; SKARZINSKY, 2002) 


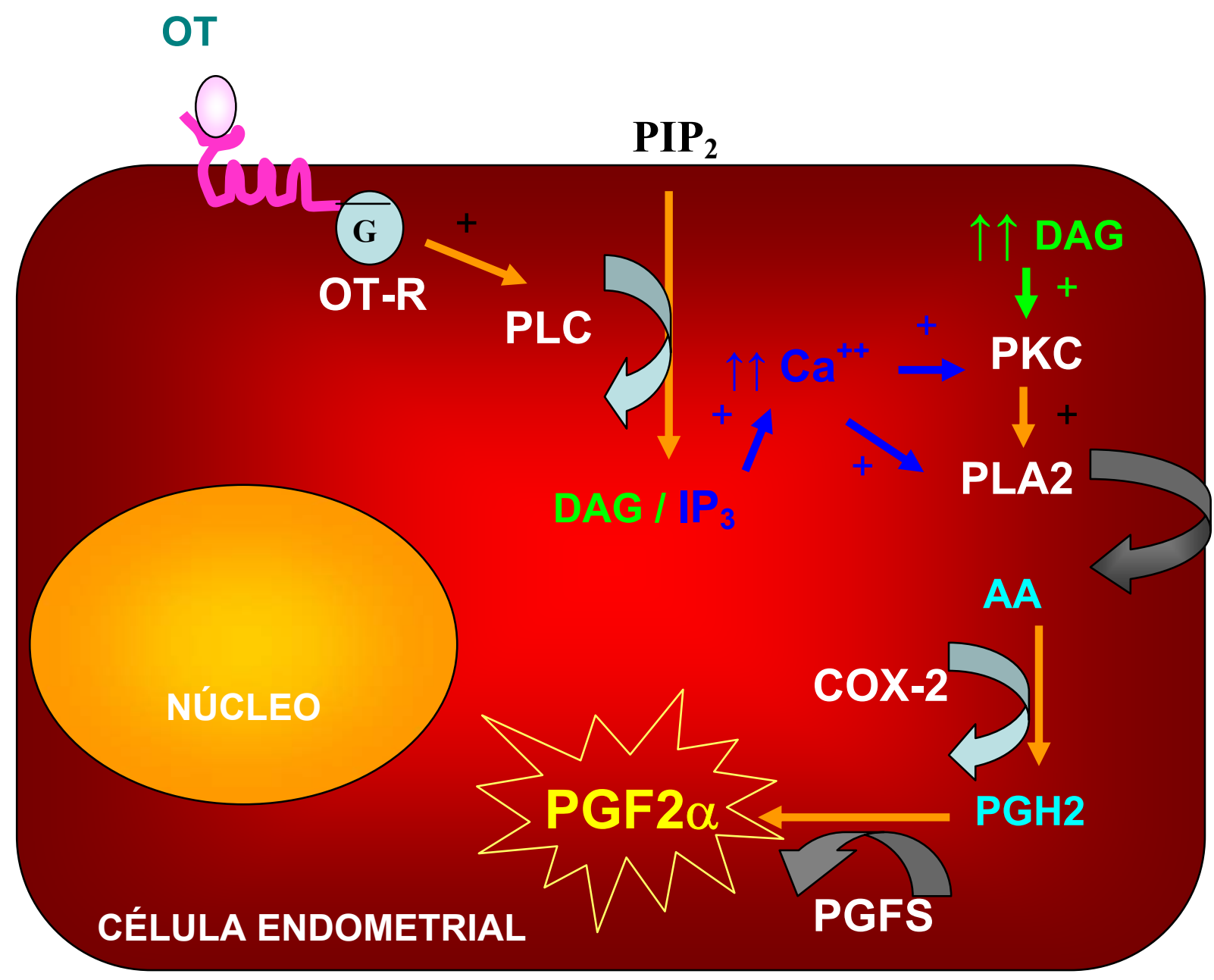

Figura 1 - Esquema ilustrando a biossíntese de PGF2 $\alpha$ a partir do ácido araquidônico nas células endometriais bovinas, segundo modelo proposto por Burns et al., 1997. A OT (OT) se liga ao seu receptor (OT-R) e este associa-se à proteína $\mathrm{G}(\mathrm{G})$ e ativa a fosfolipase $\mathrm{C}$ (PLC) que cliva o fosfatidilinositol bifosfato $\left(\mathrm{PIP}_{2}\right)$ em inositol trifosfato $\left(\mathrm{IP}_{3}\right)$ e diacilglicerol (DAG). O IP 3 se liga a receptores específicos no retículo endoplasmático, permitindo a liberação de cálcio $\left(\mathrm{Ca}^{++}\right)$para o citosol. O DAG e o cálcio ativam a proteína quinase $\mathrm{C}(\mathrm{PKC})$. A PKC juntamente com o cálcio fosforila a fosfolipase $\mathrm{A}_{2}$ $\left(\mathrm{PLA}_{2}\right)$ que cliva o ácido araquidônico (AA). A seguir, o AA livre é convertido a prostaglandina $\mathrm{H}_{2}\left(\mathrm{PGH}_{2}\right)$ pela enzima ciclooxigenase $2(\mathrm{COX}-2)$. A $\mathrm{PGH}_{2}$ é convertida à prostaglandina PGF2 $\alpha$ (PGF2 $\alpha$ ) pela ação da PGF sintase (PGFS). 
A prostaglandina é determinada de maneira específica em razão do tipo de célula. A síntese das prostaglandinas específicas como a $\mathrm{PGE}_{2}, \mathrm{PGF}_{2} \alpha, \mathrm{PGD}_{2}$ ou $\mathrm{PGI}_{2}$ é catalizada pela PGE sintase, PGF sintase, PGD sintase e PGI sintase, respectivamente (SMITH, 1992). A síntese de PGF2 $\alpha$ não é produzida somente pela redução da $\mathrm{PGH}_{2}$ pela $\mathrm{PGF} 2 \alpha$ sintase, mas também pela redução da $\mathrm{PGE}_{2}$ pela 9-keto-redutase (DANET-DESNOYERS; WETZELS; THATCHER, 1994). A PGF2 $\alpha$ é produzida principalmente pelas células epiteliais da região intercaruncular do endométrio (KIM; FORTIER, 1995; ASSELIN et al., 1996; SKARZINSKY; MIYAMOTO; OKUDA, 2000). Estas células liberam PGF2 $\alpha$ através da sua superfície basal (ASSELIN et al., 1996).

\subsection{POSSÍVEIS MECANISMOS MOLECULARES DE ATUAÇÃO DO ESTRADIOL NA SÍNTESE DE PGF2 $\alpha$}

Em ruminantes receptores de $\mathrm{E}_{2}$ e $\mathrm{P}_{4}$ foram observados no epitélio uterino, estroma e miométrio. As concentrações de tais receptores variaram ao longo do ciclo estral em resposta as diferentes concentrações plasmáticas dos hormônio esteróides (BOSS et al., 1996). Os receptores de $\mathrm{E}_{2}$ estão presentes em altas concentrações na presença de baixas concentrações plasmáticas de $\mathrm{P}_{4}$, sendo as concentrações dos receptores diminuídas na presença de altas concentrações de $\mathrm{P}_{4}$ (FINDLAY et al., 1982; ZELINSKI et al., 1982; VESANAN et al., 1991; BOSS et al., 1996). De fato, a menor expressão de RNAm para os receptores de $E_{2}$ foi verificada entre o 12 e $15^{\circ}$ dias do ciclo estral, expressão que foi significativamente aumentada a partir do $16^{\circ}$ dia (ROBINSON et al., 2001).

Os receptores de estrógenos (ER) foram divididos em dois subtipos: ER $\alpha$ e ER $\beta$. Ambos os subtipos estão presentes no endométrio bovino (KUIPER et al., 1996; ROSENFELD et al., 1998). Os ER $\alpha$ e ER $\beta$ foram identificados na membrana celular e no 
núcleo (RAZANDI et al., 1999). Normalmente, os ER $\alpha$ quando ativados pelo ligante induzem a respostas celulares imediatas, que independem da transcrição gênica. Essas respostas celulares não são bloqueadas por inibidores de proteínas ou inibidores da síntese de RNAm, pois independem da transcrição gênica. Neste mecanismo, a via é estimulada na membrana plasmática e a resposta celular é decorrente do recrutamento de segundos mensageiros, incluindo o cálcio, que desencadeia uma seqüência específica de eventos celulares que geram uma rápida resposta celular (ACCONCIA; MARINO, 2003).

Hamm (1998) verificou que a ativação dos ER localizados na membrana promoveu um aumento de $\mathrm{IP}_{3}$. Assim, hipotetizou-se que o $\mathrm{E}_{2}$ poderia se ligar a ER de membrana e tal complexo estimularia a proteína G que ativaria PLC, enzima responsável pela clivagem do $\mathrm{PIP}_{2}$ em IP $\mathrm{IP}_{3}$ e DAG. De fato, Razandi et al. (1999) demonstraram que os ER $\alpha$ e ER $\beta$ presentes na membrana celular, quando ativados estimulam sinais de transdução através da ativação das proteínas Gs e Gq. As proteínas Gs quando ativadas promoveram um aumento de AMPc, enquanto a ativação de Gq promoveu um aumento de $\mathrm{IP}_{3}$. Os mesmos autores verificaram os ER nucleares e de membrana são sintetizados por único gene, entretanto, a grande maioria dos ER sintetizados são nucleares. Pappas, Gametchu e Watson (1995) verificaram que a afinidade do $E_{2}$ ao ER nucleares e de membrana celular foi semelhante.

Razandi et al. (1999) verificaram, em células ovarianas de hamsters, que a ativação dos ER $\alpha$ e ER $\beta$ pelo $E_{2}$ estimulou a atividade das quinases reguladas por sinais extracelulares (ERK). Tal estímulo foi observado 10 minutos após as células terem sido incubadas na presença de $17 \beta$-estradiol, e o aumento foi de 3 a 4 vezes comparado ao grupo não tratado. A rápida estimulação verificada sugere um efeito mediado pela ativação dos ER de membrana. A ERK contribui para o efeito mitogênico de proliferação celular induzido pelo $17 \beta$-estradiol. Os mesmos autores verificaram que a capacidade de ativação da ERK pelo $17 \beta$-estradiol foi reduzida em $70 \%$ quando adicionou-se ao meio anticorpos ER $\alpha$. Possivelmente a ação do 
17ß-estradiol em estimular a atividade ERK seja resultado da sua interação com ER $\alpha$ localizados na membrana celular. Segundo Alberts et al. (1997), considerando que a ERK são quinases ativadas por mitógenos, cria-se a possibilidade das mesmas serem estimuladas por uma grande variedade de sinais extra celulares indutores da proliferação celular. Dentre estes sinais, alguns ativam receptores tirosinoquinases, enquanto outros ativam receptores associados à proteína G (ALBERTS et al., 1997).

Em outro estudo, células endometriais humanas (linhagem RL95-2) o 17 $\beta$-estradiol induziu a um rápido aumento de cálcio intracelular ocasionado pelo influxo de cálcio pelos canais de cálcio. Sugeriu-se que uma das ações não genômicas do $E_{2}$ seria promovida pela entrada de cálcio nas células (PERRET; DOCKERY; HARVEY, 2001). De fato, em células endometriais de ratas, concentrações fisiológicas de 17ß-estradiol promoveu rapidamente (menos de 10 minutos) um aumento de cálcio intracelular (PIETRAS; SZEGO, 1975). O cálcio mostrou ser essencial na transdução de sinal, responsável pela rápida resposta celular promovida pelo $E_{2}$ (REVELLI; MASSOBRIO; TESARIK, 1998). No endométrio, a ação do cálcio intracelular parece ser dependente das metaloproteases dependentes de cálcio, relatadas como potentes mediadoras na ação de muitos hormônios (TABIBZADEH, 1998). Outro possível alvo do cálcio envolve a síntese de óxido nítrico importante na modulação do sistema vascular do endométrio e na atividade das proteases no epitélio basal (DOCKERY et al., 1998). O cálcio intracelular também está envolvido no decréscimo do número e tamanho das junções "tight" entre as células epiteliais assim como a modulação do transporte de íons (CHAN et al.,1997).

Segundo Razandi et al. (1999) a maior ação dos hormônios esteróides ocorre pela ativação dos ER nucleares que ocasionam efeitos na transcrição de genes específicos. Durante os últimos anos, o conhecimento dos mecanismos moleculares pelos quais os ER nucleares atuam nas células foi amplamente estudado, entretanto, os mecanismos moleculares pelos 
quais estes receptores estimulam a transcrição gênica ainda são pouco esclarecidos. Os ER nucleares regulam a transcrição gênica por se ligarem a seqüências específicas de DNA e estimularem ou inibirem a expressão de um determinado gene. De fato, Acconcia e Marino (2003) verificaram que ação genômica do $E_{2}$ na célula é promovida pelo complexo $E_{2}$-ER que ativa fatores transcripcionais ligados ao DNA (ACCONCIA; MARINO, 2003). Os mesmos autores verificaram haver um sinergismo entre a ação molecular genômica e não genômica do $\mathrm{E}_{2}$ induzindo a transcrição de genes, sendo a ativação da via ERK essencial para o $\mathrm{E}_{2}$ induzir a atividade por ambas as vias.

Razandi et al. (1999) observaram que o ER $\beta$ ligado ao $E_{2}$ é capaz de ativar a atividade da c-Jun quinase (JNK), enquanto a ativação de ER $\alpha$ inibe a atividade de JNK. A transcrição dependente de AP-1 é ativada por ER $\beta$. AP-1 é composta por heterodímeros da família fos/jun, onde c-jun é um substrato natural da JNK e quando ativado aumenta a atividade AP1. A c-jun ativada por JNK atuaria participando dos sinais de transdução e teria efeito direto na transcrição gênica. Entretanto, Aranda e Pascual (2001) relataram que a ativação de ER $\alpha$ ativa a transcrição, enquanto a ativação de ER $\beta$ inibe a transcrição dependente de AP-1.

Baseando-se nas considerações anteriores o $\mathrm{E}_{2}$ poderia exercer efeitos diretos na síntese de PGF2 $\alpha$ no endométrio. Tais efeitos resultariam da ação direta do $\mathrm{E}_{2}$ aumentando a síntese de proteínas responsáveis pela produção de PGF2 $\alpha$. XIAO et al. (1998) determinaram que o tratamento das células epiteliais do endométrio com $\mathrm{E}_{2}$ reduziu a expressão do gene COX-2. É possível que o $E_{2}$ estimule a expressão e/ou a atividade de outras moléculas, que não COX-2, no aparelho gerador de PGF2 $\alpha$.

Uma outra possibilidade para a ação do $E_{2}$ na produção de PGF2 $\alpha$ seria por ação indireta, através da indução da síntese dos receptores de OT no endométrio, permitindo a ligação de OT endógena a estes receptores, estimulando a síntese de PGF2 $\alpha$ (CASTRO E PAULA, 2003). McCracken, Schramm e Okulicz (1999) hipotetizaram que o $E_{2}$, tendo sua 
ação tecidual retomada após a diminuição da ação da $\mathrm{P}_{4}$, aumentaria os receptores endometriais para a OT e estimularia a secreção de OT no hipotálamo. De fato, demonstrouse com uma série de estudos in vivo que o $\mathrm{E}_{2}$ é capaz de estimular a expressão dos receptores endometriais de OT (HIXON; FLINT, 1987; BEARD; LAMMING, 1994; SPENCER et al., 1995). Outra possibilidade seria através da indução da produção e/ou ativação dos receptores de LH no endométrio. A ligação do LH aos seus receptores estimularia a síntese de PGF2 $\alpha$. De fato, o endométrio bovino apresenta receptores $\mathrm{LH} / \mathrm{hCG}$ em grande quantidade entre os dias 15 a 17 do ciclo estral que desaparecem logo após a luteólise (SHEMESH et al., 1996; FRIEDMAN; GUREVICH; SHEMESH, 1995). CANINO et al. (1999) avaliaram a associação do LH ao $E_{2}$ no processo de síntese de PGF2 $\alpha$. Nesse estudo, vacas ovariectomizadas pré-tratadas com $\mathrm{P}_{4}$ receberam uma injeção de $\mathrm{E}_{2}$ que promoveu a liberação de PGFM. Injeções de gonadotrofina coriônica humana (hCG; um agonista de LH) 4 horas após a injeção de $\mathrm{E}_{2}$ estimularam uma resposta de PGFM cinco vezes maior comparada aos animais que receberam somente $\mathrm{E}_{2}$. Contudo, quando o hCG foi administrado na ausência do pré-tratamento com $E_{2}$ não houve estímulo à liberação de PGFM. No mesmo estudo, injeções de GnRH para liberar LH da adenohipófise estimularam a secreção de PGFM exclusivamente em vacas pré-tratadas com $\mathrm{E}_{2}$.

Fields et al. (1999) demonstraram que em fragmentos endometriais originados de vacas nos dias 2 a 4 do ciclo, incubados durante 10 minutos na presença ou ausência de LH (5, 10 e 20ng/mL), a concentração de AMP cíclico (AMPc) não foi aumentada. Entretanto, o LH induziu a um aumento na produção de AMPc nos fragmentos dos dias 15 a 17 cerca de 2,5 vezes maior na dose de $10 \mathrm{ng} / \mathrm{ml}$, caracterizando uma resposta dose dependente. Quando fragmentos endometriais de vacas prenhes (com 30 a 60 dias de gestação) receberam o tratamento com LH não foi observado aumento nas concentrações de AMPc. Em fragmentos endometriais no dia 16 do ciclo estral, tratados com $10 \mathrm{ng} / \mathrm{mL}$ de $\mathrm{LH}(10 \mathrm{ng} / \mathrm{mL})$ verificou-se 
uma elevação nas concentrações de $\mathrm{IP}, \mathrm{IP}_{2}$ e $\mathrm{IP}_{3}$. Assim, possivelmente o LH seja um regulador endógeno da luteólise uma vez que foi capaz de estimular a secreção de PGF2 $\alpha$ na presença do $\mathrm{E}_{2}$ e que o LH possa mediar as ações do $\mathrm{E}_{2}$ que estimulam a síntese de PGF2 $\alpha$.

A presente tese tem como objetivo investigar o possível mecanismo de atuação do $\mathrm{E}_{2}$ na síntese de PGF2 $\alpha$. Para tanto, o $\mathrm{E}_{2}$ foi associado a diferentes estimuladores celulares da síntese de PGF2 $\alpha$ no meio de cultivo de explantes e células endometriais. Cada estimulador utilizado atua em um ponto específico da cascata geradora de PGF2 $\alpha$. A ação dos estimuladores utilizados será descrita a seguir.

\subsection{ESTIMULADORES CELULARES DA SÍNTESE DE PGF2 $\alpha$}

Na década passada, houve um grande progresso no conhecimento de como as células utilizam o cálcio para regular suas atividades. $\mathrm{O}$ segundo mensageiro $\mathrm{IP}_{3}$ atua no controle da mobilização interna e externa de cálcio na célula. No compartimento intracelular o $\mathrm{IP}_{3}$ pode ser gerado por duas vias. Na primeira, receptores ativados são acoplados a proteína $\mathrm{G}$ e estimulam a PLC- $\beta$, enquanto por outra via receptores ativados ligam-se a uma tirosinaquinase que estimula especificamente a PLC- $\gamma$ (BERRIDGE, 1993).

A PKC faz parte da família das proteínas quinases serina/treonina que tem um importante papel na transdução de sinal em várias respostas celulares. A família PKC foi dividida em três subfamílias (HOFMANN, 1997): 1) PKCs Clássicas ou Convencionais (PKC $\alpha$, PKCßI, PKC $\beta I I$ e PKC $\gamma$ ) são dependentes de cálcio e fosfolipídeos; 2) PKCs Novas ( $\mathrm{PKC} \delta, \mathrm{PKC} \varepsilon, \mathrm{PKC} \eta, \mathrm{PKC} \theta)$ não possuem um domínio de ligação para o cálcio e não requerem cálcio para sua ativação; 3) $\mathrm{PKCs}$ Atípicas ( $\mathrm{PKC} \zeta, \mathrm{PKC} \lambda, \mathrm{PKC}$ e $\mathrm{PKC} \mu$ ) não dependem de cálcio ou fosfolipídeos para a ativação. Cada isotipo de PKC desenvolve um papel fisiológico (CHUN; HÁ; JACOBSON, 1996). Em extrato de células endometriais 
bovinas (células BEND) foram identificados por Western Blotting os isotipos $\alpha, \varepsilon, \imath$ e $\lambda$ de PKC (GUZELOGLU et al., 2004).

A estrutura molecular das $\mathrm{PKCs}$ incluem regiões regulatórias e catalíticas. A região regulatória é constituída por dois domínios $(\mathrm{C} 1$ e $\mathrm{C} 2)$ e um sítio pseudosubstrato. A ativação fisiológica e química do domínio $\mathrm{C} 1$ é realizada pelo DAG ou fórbol éster, respectivamente. O domínio C2 é o sítio de ligação para o cálcio presente nas isoformas de PKC dependentes de cálcio. As PKCs convencionais possuem ambos os domínios $(\mathrm{C} 1$ e $\mathrm{C} 2)$ e são dependentes de cálcio e fosfolipídeos. As novas PKCs não tem o domínio C2 e sua ativação independe do cálcio. As PKCs atípicas não possuem domínio C2 e têm um domínio $\mathrm{C} 1$ diferenciado, que independe de cálcio e fosfolipídeos. A região catalítica também possui dois domínios $(\mathrm{C} 3 \mathrm{e}$ C4). A região catalítica está presente em todos os isoformas de PKC. O sítio pseudosubstrato é uma região reguladora que tem uma estrutura similar ao substrato PKC e bloqueia o sítio catalítico inativando as PKCs. A ativação das PKCs convencionais e novas requer DAG que seletivamente aumenta a afinidade da PKC pela membrana da célula e libera o pseudosubstrato do sítio catalítico. A ativação da PKC parece ser crítica na secreção de PGF2 $\alpha$, pois está implicada na ativação de determinados genes e na estimulação da síntese de proteínas (SRINIVASAN; BLUNDELL, 1997).

A ativação da PKC pode ser farmacologicamente induzida pelo uso de fórbol ésters. Tais compostos tem sido utilizado para induzir a secreção de prostaglandina em células endometriais primárias ou explantes cultivados (ARNOLD et al., 2000; XIAO et al., 1999) e células endometriais bovinas BEND (BINELLI et al., 2000; PRU et al., 2001; GUZELOGLU et al., 2004). A ativação da PKC por fórbol ésters resultou no aumento de RNAm e na expressão da COX-2 em células endometriais bovinas (BINELLI et al., 2000; XIAO et al., 1999). Uma diferença entre o ativador natural DAG e o fórbol éster é que o DAG tem uma meia-vida curta, sendo rapidamente metabolizado (NISHIZUKA, 1992) enquanto o fórbol 
éster não é degradado nas células e associa-se as PKCs da membrana por um longo tempo nas células (NISHIZUKA et al., 1984). GUZELOGLU et al. (2004) observaram que em células BEND tratadas com fórbol éster a PKC $\alpha$ foi especialmente ativada e induziu a um aumento na síntese de PGF2 $\alpha$, tendo sua concentração diminuído no citoplasma. Para a ativação da PKC é requerida a translocação da enzima inativa do citoplasma para a membrana celular onde ocorre a ação do DAG e do cálcio. A diminuição de $\mathrm{PKC} \alpha$ no citoplasma poderia ser decorrente de sua translocação para membrana requerida para a ativação ou por um aumento na degradação da mesma. Os mesmos autores, utilizaram a técnica de Western blotting para verificar se PKC $\alpha$ teria sido aumentada ou diminuída na membrana celular em resposta ao PDBu, entretanto, tal técnica não foi suficientemente sensível.

Ruzycky e Kulick (1996) estudaram a expressão da PKC no miométrio e em células da musculatura cardíaca ventricular de ratas ovariectomizadas pré-tratadas com $17 \beta$-estradiol associado ou não à $\mathrm{P}_{4}$. A expressão da $\mathrm{PKC}$ foi avaliada por imunoblotting na membrana $\mathrm{e}$ fração subcelular do citosol. Quando $\mathrm{o} \mathrm{E}_{2}$ foi associado à $\mathrm{P}_{4}$ a expressão da $\mathrm{PKC}$ na membrana foi aumentada de 35 a 125\% nas células do miométrio, efeito não observado nas células cardíacas. Os autores sugeriram que o efeito de hipertrofia e aumento da contratilidade uterina promovido pelo $\mathrm{E}_{2}$ está associado ao aumento da $\mathrm{PKC}$ na membrana, efeitos específicos deste tecido.

A PLA $_{2}$ apresenta um domínio de ligação para o cálcio e na presença deste liga-se a membrana (CHANNON; LESLIE, 1990; CLARK et al., 1991). O aumento das concentrações de cálcio intracelular in vitro com o ionóforo de cálcio A23187 resultou em um aumento da liberação de PGF2 $\alpha$ no tecido endometrial de ovinos (SILVIA; HOMANICS, 1988; RAW; SILVIA, 1991) e bovinos (BURNS; HAYES; SILVIA, 1998). Segundo Burns, Hayes e Silvia (1998) o endométrio bovino pode ser estimulado por uma variedade de agentes farmacológicos que promove um acúmulo de cálcio no citoplasma (ionóforo de cálcio 
A23187, maitotoxina e tapsigargina), enquanto tratamentos que inibem o acúmulo de cálcio no citoplasa $\left(\mathrm{CoCl}_{2}\right.$ e D600) inibiram a síntese de PGF2 $\alpha$ no tecido endometrial estimulado pela OT. O A23187 promove um influxo de cálcio extracelular, a maitotoxina ativa os canais de cálcio tipo-L e a tapsigargina aumenta as concentrações de cálcio no citosol pela inibição da $\mathrm{Ca}^{++} /$ATPase que desloca o cálcio do citosol para o retículo endoplasmático. $\mathrm{O} \mathrm{CoCl}_{2}$ bloqueia os canais de cálcio enquanto o D600 inibe os canais de cálcio tipo-L. O aumento das concentrações citoplasmáticas de cálcio parece ser um componente essencial no mecanismo regulatório intracelular da síntese de $\mathrm{PGF} 2 \alpha$. Na presença de cálcio a PLA 2 atinge sua ativação máxima quando há a fosforilação da serina 505, um substrato ativado pelas MAPK (GRAF; BURNS; SILVIA, 1999).

O ionóforo de cálcio foi capaz de aumentar a síntese de prostaglandina no endométrio de porcas (BASHA; BAZER; ROBERTS, 1980), ovelhas (RAW; SILVA, 1991) e em cobaias (POYSER, 1987). Entretanto, Lafrance e Goff (1990) não observaram o efeito estimulatório do ionóforo de cálcio na secreção de prostaglandina em explantes de novilhas nos dias 19 ou 20 do ciclo estral. Danet-Desoyers et al. (1995) observaram um efeito estimulatório do ionóforo de cálcio na síntese de PGF2 $\alpha$ em vacas.

Um mecanismo modulatório que pode estar envolvido na degradação da PKC envolve várias proteases (KISHIMOTO; MIKAWA; HASHIMOTO, 1989). Goode et al. (1995) sugeriu que em mamíferos os diferentes isoformas de PKC diferiram na susceptibilidade a "downregulation". Tal processo pode ser resultante de um aumento na taxa de degradação e estável expressão da PKC nas células (YOUNG et al., 1987).

A PKC ativa a PLA 2 em muitos tipos de células e o aumento da atividade da PLA foi associada ao aumento na síntese de PGF2 $\alpha$. Burns et al. (1997) trataram explantes endometriais de fêmeas bovinas com melitina, substância que ativa PLA 2 , e observaram um 
aumento na síntese de PGF2 $\alpha$. Nesse estudo a melitina foi mais efetiva em estimular a síntese de PGF2 $\alpha$ que a OT.

Flint et al. (1986a) demonstraram que a OT estimulou um rápido aumento na atividade de PLC em cultivo de endométrio ovino, observações que posteriormente foram reconfirmadas (SILVIA; HOMANICS, 1988; VALET; BAZER, 1989, WALLACE et al., 1993). Lafrance e Goff (1990) observaram que a OT não estimulou a liberação PGF2 $\alpha$. Entretanto, Burns et al. (1997) verificaram que a OT estimulou a um rápido aumento da secreção de PGF2 $\alpha 30$ minutos após a incubação dos explantes endometriais com a OT. O aumento de PGF2 $\alpha$ foi associado a um aumento da atividade da PLC, sendo observada uma estimulação máxima com a dose de $10^{-6} \mathrm{M}$ de OT. Sugeriu-se que a OT estimula a síntese de PGF2 $\alpha$.

\subsection{MODELO EXPERIMENTAL DE CULTIVO COM CELULAS ENDOMETRIAIS BOVINAS (BEND)}

Os modelos experimentais in vitro são de grande importância para os estudos relacionados a luteólise. A principal vantagem destes modelos experimentais reside na possibilidade de verificar a resposta de células e tecidos a fatores que podem ser administrados isoladamente ou em associações pré-determinadas. Dessa fora elimina-se possíveis confundimentos inerentes a estudos realizados in vivo.

Muitos estudos pertinentes à fisiologia e endocrinologia uterina utilizam-se de culturas primárias de células bovinas, obtidas por métodos dissociativos mecânicos e enzimáticos, ou explantes de tecidos endometriais (DANET-DESNOYERS et al., 1995; XIAO; GOFF, 1999; KOMBÉ; SIROIS; GOFF, 2003). Tais métodos envolvem a obtenção rotineira de tecidos animais em abatedouros, incorrendo no uso significativo de mão-de-obra, reagentes, recursos 
financeiros e um número considerável de animais abatidos. Outro fator a ser considerado é a alta variabilidade individual na secreção de PGF2 $\alpha$ entre os animais (CASTRO E PAULA et al., 2002). Como uma alternativa diante dessas limitações, as células BEND (STAGGS et al., 1998) foram desenvolvidas.

As células endometriais bovinas BEND consistem em uma linhagem de células endometriais obtidas no dia 14 do ciclo estral em fêmeas bovinas, que adquiriram espontaneamente a capacidade de replicação in vitro. A linhagem de células BEND foi caracterizada e registrada na American Type Culture Colection (ATCC n CRL-2398), onde encontra-se descrita toda a metodologia para o cultivo das mesmas. As células BEND podem ser utilizadas repetidamente por até 25 passagens, não apresentando nenhuma alteração fenotípica (BINELLI et al., 2000).

Além de se apresentarem morfologicamente semelhantes às células endometriais epiteliais, as células BEND são capazes de responder a estimuladores e inibidores da produção de PGF2 $\alpha$ (BINELLI et al., 2000; GUZELOGLU, MICHEL; THATCHER, 2004) e têm sido utilizadas em estudos para elucidar os mecanismos celulares e moleculares na manutenção da prenhez em bovinos (STAGGS et al., 1998; PERRY; AUSTIN; HANSEL, 1999; BINELLI et al., 2000; PRU et al., 2000; PRU et al., 2001).

As células BEND são especialmente indicadas para estudos relacionados à regulação da produção de PGF2 $\alpha$ no endométrio no final da fase luteínica. Isto porque as células BEND são oriundas de animais no $14^{\circ}$ dia do ciclo estral, e por isso receberam in vivo a sensibilização pela $\mathrm{P}_{4}$, necessária para o desencadeamento da produção de PGF2 $\alpha$. Além disso, são consideradas bioquimicamente preparadas para a produção de PGF2 $\alpha$ frente à estímulos diversos.

Binelli et al. (2000) verificaram que as células BEND respondem positivamente ao tratamento com um estimulador da síntese de PGF2 $\alpha$, o forbol 12,13 dibutirato (PDBu, 
estimulador da PKC), tal qual o fazem explantes endometriais obtidos no $15^{\circ}$ dia do ciclo estral (CASTRO E PAULA, et al., 2001; LOUREIRO et al., 2001). Binelli et al. (2000) verificaram que a síntese de PGF2 $\alpha$ induzida pelo PDBu nestas células pode ser inibida quando ao meio de cultivo é adicionado IFN- $\tau$. No mesmo estudo, células BEND tratadas

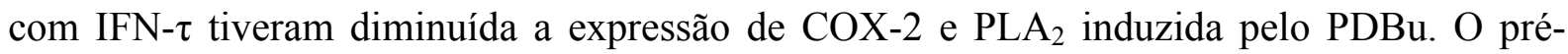
tratamento das células BEND com somatotropina bovina recombinante (rbGH) ou com fator de crescimento semelhante à insulina (IGF)-I foi capaz de potencializar os efeitos do PDBu na produção de PGF2 $\alpha$ e de mRNA de COX-2 (BADINGA; GUZELOGLU; THATCHER, 2002). Células BEND pré-tratadas com ácidos graxos polinsaturados tiveram a produção de PGF2 $\alpha$ induzida pelo PDBu diminuída (MATTOS et al., 2003). No mesmo estudo foi verificada a capacidade do IFN- $\tau$ de inibir a produção do mRNA da PGHS-2 nas células BEND.

Estes dados demonstram que as células BEND guardam importantes semelhanças com a fisiologia e a endocrinologia endometrial observada in vivo, sendo por isso consideradas um excelente modelo in vitro para o estudo dos mecanismos moleculares envolvidos na produção de PGF2 $\alpha$ pelo útero.

Uma das vantagens das células BEND enquanto modelo in vitro de estudo, reside na baixa variabilidade na produção de PGF2 $\alpha$ entre as unidades de cultivo. O contrário ocorre em cultura de tecido endometrial, mesmo que todos os fragmentos sejam oriundos de um mesmo animal, o que pode dificultar a padronização de resultados experimentais (CASTRO E PAULA, et al., 2001; LOUREIRO et al., 2001). Destaca-se ainda a rapidez e a facilidade na realização estudos com cultivos celulares.

Sugere-se a partir de tais características que as células BEND se assemelham fisiologicamente e endocrinologicamente ao tecido endometrial, originando um modelo biológico que permite avaliar de maneira eficaz a síntese de PGF2 $\alpha$ mediante a um 
tratamento. Assim, a utilização de tal modelo experimental ampliou a capacidade de estudos sobre os mecanismos moleculares pelos quais o $\mathrm{E}_{2}$ estimula a síntese de PGF2 $\alpha$. 
3. OBJETIVOS

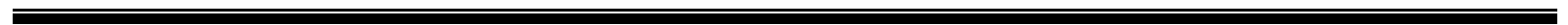




\section{OBJETIVOS}

\subsection{OBJETIVO GERAL}

- Investigar os mecanismos endócrinos e moleculares pelos quais o estradiol estimula a síntese de PGF2 $\alpha$ endometrial em fêmeas bovinas.

\subsection{OBJETIVOS ESPECÍFICOS}

$\checkmark \quad$ Comparar a capacidade secretória de PGF2 $\alpha$ estimulada pelo estradiol em diferentes dias do ciclo estral $\left(13^{\circ}\right.$ ao $19^{\circ}$ dia do ciclo) com o intuito de estabelecer um modelo experimental de estudo in vivo e in vitro (Experimento 1);

- Avaliar a ação direta do estradiol nos componentes da cascata geradora de prostaglandina utilizando estimuladores celulares específicos (Experimento 2);

$\checkmark \quad$ Mensurar a capacidade das células BEND sintetizarem PGF2 $\alpha$ quando tratadas com ionóforo de cálcio e determinar a dose capaz de promover tal estímulo (Experimento 3);

$\checkmark \quad$ Mensurar a capacidade das células BEND em sintetizarem PGF2 $\alpha$ quando tratadas com estradiol e/ou ionóforo de cálcio (Experimento 4). 
4. EXPERIMENTO 1: PRODUÇÃO DE PGFM EM RESPOSTA A ADMINISTRAÇÃO DE ESTRADIOL ENTRE OS DIAS 13 E 19 DO CICLO ESTRAL 


\section{EXPERIMENTO 1: PRODUÇÃO DE PGFM EM RESPOSTA A ADMINISTRAÇÃO DE ESTRADIOL ENTRE OS DIAS 13 E 19 DO CICLO ESTRAL}

\subsection{JUSTIFICATIVA}

Em fêmeas bovinas a administração de $3 \mathrm{mg}$ de $17 \beta$-estradiol a partir do $13^{\circ}$ dia do ciclo estral (dia $0=$ estro) ocasionou um aumento nas concentrações plasmáticas de PGFM (KNICKERBOCKER et al., 1986; THATCHER et al., 1979; THATCHER et al., 1986). Além disso, vacas submetidas a tal tratamento tiveram os estros antecipados quando comparadas às do grupo controle (THATCHER et al., 1986). Entretanto, em estudos realizados no Laboratório de Fisiologia e Endocrinologia Molecular (CASTRO E PAULA, 2003) a resposta estimulatória à síntese de PGFM não foi observada em todas as fêmeas quando tratadas com $\mathrm{E}_{2}$ no $15^{\circ}$ dia do ciclo estral.

Assim, julgou-se necessária a realização do presente experimento, para determinar o dia fisiologicamente propício para o estudo dos mecanismos pelos quais o $E_{2}$ estimula a síntese de PGF2 $\alpha$. Entende-se como o dia fisiologicamente propício, o momento em que o endométrio estaria suficientemente estimulado por outros fatores que participam da síntese de PGF2 $\alpha$ junto ao $E_{2}$, condição que favoreceria um estímulo consistente na síntese de PGF2 $\alpha$ após a administração de $E_{2}$. Entretanto, nesse dia a luteólise fisiológica ainda não deveria ter sido iniciada.

Esse estudo objetivou relacionar o aumento das concentrações de PGFM em fêmeas bovinas tratadas com $17 \beta$-estradiol com o dia do ciclo estral no período que antecede a luteólise $\left(13^{\circ}, 15^{\circ}, 17^{\circ}\right.$ e $19^{\circ}$ dias do ciclo estral). Tal avaliação tornou-se imprescindível para o estabelecimento de um modelo fisiológico in vivo e in vitro. 
A hipótese foi que a resposta estimulatória a síntese de PGF2 $\alpha$ endometrial pelo $E_{2}$ é crescente ao longo dos dias do ciclo estral.

\subsection{MATERIAL E MÉTODO}

Animais. Foram utilizadas 12 vacas holandesas secas, de idade variável, vazias, não lactantes, sendo os estros sincronizados com intervalos de dois dias entre os grupos a fim de que no dia determinado para o estudo (dezenove dias após a primeira vaca ter entrado em estro) os animais estivessem em diferentes dias do ciclo (entre D13 e D19), considerando o estro como D0. Os animais foram mantidos em piquetes, com água a disposição. A alimentação foi baseada no pastejo (Brachiaria spp.) com suplementação mineral e energética. Todos os animais foram vermifugados, vacinados e submetidos a exames para controle de tuberculose e brucelose.

Local do Experimento. O experimento foi realizado na Universidade de São Paulo, na Faculdade de Medicina Veterinária e Zootecnia, na cidade de Pirassununga - SP, nas dependências do Centro de Biotecnologia em Reprodução Animal, no Laboratório de Fisiologia e Endocrinologia Molecular (LFEM) em junho de 2002.

Delineamento Experimental. O método utilizado para a sincronização dos estros constituiu-se da implantação de dispositivos intravaginais contendo $\mathrm{P}_{4}$ (CIDR $®$-Pfizer) associados a uma injeção de $100 \mu \mathrm{g}$ de gonadorelina, um GnRH sintético (Fertagil ${ }^{\circledR}$ Intervet), no D0. A remoção do implante, realizado no D7, foi acompanhado de uma injeção de $150 \mu \mathrm{g}$ de D-cloprostenol (Preloban ${ }^{\circledR}$ - Intervet), um análogo sintético de PGF2 $\alpha$. No mesmo dia aplicou-se uma tinta marcadora na base da cauda das vacas (All-Weather 
Paintstik®, LA-CO Industries, Inc.), utilizada como método auxiliar na detecção de estros. O comportamento de estro foi observado de 48 até 120 horas após a aplicação de PGF2 $\alpha$, a cada 12 horas, tendo sido considerado o dia do estro como o dia 0 do ciclo estral. No D6 do ciclo sincronizado os animais foram examinados por ultra-sonografia para a verificação da presença de um folículo com diâmetro $\geq 8 \mathrm{~mm}$. Havendo a presença de tal folículo, o animal recebeu uma injeção de $100 \mu \mathrm{g}$ de gonadorelina (Fertagil ${ }^{\circledR}$ - Intervet). O objetivo deste procedimento, foi induzir a ovulação do folículo dominante da primeira onda e ocasionar um ciclo estral de três ondas foliculares em todas as fêmeas (DIAZ et al., 1998). Novo exame ultra-sonográfico foi realizado 48 horas após o tratamento com gonadorelina, para a verificação da ovulação do folículo dominante da primeira onda. A cada dois dias um grupo de animais era submetido ao protocolo de sincronização para que no dia do experimento houvesse grupos de animais no D13, D15, D17 e D19. Os animais foram submetidos a canulação da veia jugular e exame ultra-sonográfico, para avaliar a presença de um CL acessório, 24 horas antes do início do experimento (Anexo A1).

No dia do tratamento com $\mathrm{E}_{2}$, vacas em diferentes fases do ciclo constituíram os seguintes grupos: Grupo 1 (D13; n=2), Grupo 2 (D15; n=2) Grupo 3 (D17; n=3) e Grupo 4 (D19; n=5). Todas as vacas foram tratadas com uma injeção de 17ß-estradiol (3mg; IV; hora 2) e uma injeção de OT (50UI; IV, hora 9). Em experimentos anteriores alguns animais, no $15^{\circ}$ dia do ciclo estral, não liberaram PGFM em resposta a um injeção de $E_{2}$. Contudo, fêmeas no mesmo dia do ciclo tratadas com OT tiveram as concentrações de PGFM aumentadas 30 minutos após a injeção. Dessa maneira, a injeção de OT foi utilizada como um controle positivo para garantir que uma possível ausência de resposta ao $E_{2}$ não se devia a uma incapacidade de produzir PGF2 $\alpha$. Amostras de sangue foram coletadas a cada 30 minutos da hora 0 à hora 12 (Anexo A2). As amostras foram acondicionadas a $-20^{\circ} \mathrm{C}$ e submetidas posteriormente à mensuração das concentrações de PGFM por radioimunoensaio (Anexo A3). 
Os coeficientes de variação intra-ensaio para a referência com baixa concentração $(50 \mathrm{pg} / \mathrm{mL})$ foi de $17,69 \%$ e para a referência com média concentração $(500 \mathrm{pg} / \mathrm{mL})$ foi de $3,45 \%$. Os coeficientes de variação inter-ensaio para as referências de baixa e média concentração foram de $0,95 \%$ e $0,91 \%$, respectivamente.

Análise Estatística. Os dados foram analisados e não obedeceram as premissas quanto à normalidade dos resíduos (Teste de Shapiro-Wilk, $\mathrm{P} \leq 0,01)$ e homogeneidade das variâncias (Teste $\mathrm{F}, \mathrm{P} \leq 0,01$ ). Os dados foram então transformados por logaritmo e reanalisados. Tal transformação adequou os dados à análise de variância (Shapiro-Wilk e F; P $\geq 0,01$ ). A variável dependente foi a produção de PGFM $(\mathrm{pg} / \mathrm{mL})$. Foram variáveis independentes: dia, vaca dentro de dia, tempo e interação dia x tempo. Vaca dentro de dia foi usada como termo de erro para o efeito de dia.

Os dados foram analisados por ANOVA utilizando-se o proc GLM e o proc MIXED do programa SAS. O teste de "slice" foi realizado para a comparação das médias entre os tratamentos dentro de uma mesma fração de tempo. Os dados são apresentados como LSmeans \pm EPM, não transformados. A interação dia x tempo foi analisada pela técnica de homogeneidade das regressões. As curvas de regressão dos diferentes dias foram comparadas pelos seguintes contrastes ortogonais: dia 13 vs dias 15 , 17 e 19; dia 15 vs dias 17 e 19 e dia 17 vs dia 19.

Foram realizadas análises utilizando o proc GLM do programa SAS a fim de se determinar os efeitos da variável independente "dia" segundo as diferentes variáveis dependentes sem repetição: Concentração Basal (média da concentração de PGFM antes do $\mathrm{E}_{2}$ ), Pico (concentração de PGFM sete horas após injeção de $\mathrm{E}_{2}$ ), razão Pico/Concentração Basal, Diferença Pico - Concentração Basal. As médias das variáveis acima mencionadas 
foram comparadas por uma série de contrastes ortogonais: dia 13 vs dias 15, 17 e 19; dia 15 vs dias 17 e 19 e dia 17 vs dia 19.

\subsection{RESULTADOS E DISCUSSÃO}

$\mathrm{A}$ atividade luteolítica do $\mathrm{E}_{2}$ tem sido atribuída à sua capacidade em estimular a síntese de PGF2 $\alpha$ endometrial. Considerando que em ruminantes $98 \%$ da PGF2 $\alpha$ produzida pelo útero é metabolizada em PGFM na primeira passagem pelos pulmões (PIPER; VANE; WILLIE, 1970) no presente estudo a capacidade do $E_{2}$ em estimular a síntese de PGF2 $\alpha$ nos diferentes dias do ciclo estral foi mensurada pela concentração plasmática de PGFM por radioimunoensaio. Knickerbocker et al. (1982) determinaram em vacas tratadas com $\mathrm{E}_{2}$ uma alta correlação entre a quantidade de PGF2 $\alpha$ presente na veia uterina e a concentração plasmática de PGFM na corrente sanguínea. Alguns trabalhos demonstraram que a administração de $E_{2}$ foi capaz de estimular a produção de PGFM em fêmeas bovinas no $13^{\circ}$ (THATCHER et al., 1979), $15^{\circ}$ ao $18^{\circ}$ (BERTHOLAZZI et al., 2003), $17^{\circ}$ (CASTRO E PAULA, 2003; JORGE et al., 2003) e $18^{\circ}$ dias do ciclo estral (RICO et al., 1981; KNICKERBOCKER et al., 1982). O presente experimento confirma a capacidade do $\mathrm{E}_{2}$ em estimular o aumento das concentrações séricas de PGFM no $15^{\circ}, 17^{\circ}$ e $19^{\circ}$ dias do ciclo estral, entretanto, tal estímulo não foi observado quando vacas foram tratadas com $E_{2}$ no $13^{\circ}$ dia do ciclo estral. Foi observada uma interação tempo x dia $(\mathrm{P} \leq 0,01$; Tabela 1; Gráfico 1), pois o perfil de liberação de PGFM estimulada em resposta à injeção de $E_{2}$ foi diferente ao longo do tempo nos diferentes dias do ciclo estral ( $\mathrm{P} \geq 0,1$; Tabela 2; Gráfico 2). No presente estudo a concentração basal de PGFM não diferiu entre os diferentes dias do ciclo estral. No presente estudo avaliou-se o efeito de dia nas concentrações basais e de pico de PGFM para os diferentes dias do ciclo estral. Não houve efeito na concentração basal, ou seja, as 
Tabela 1 - Análise de variância dos quadrados mínimos da concentração plasmática de PGFM de vacas nos dias $13(n=2), 15(n=2), 17(n=3)$ ou $19(n=5)$ do ciclo estral, submetidas a tratamento com 3mg de 17ß-estradiol - Pirassununga - Jun 2002

\begin{tabular}{cccc}
\hline \hline Fontes de variação & GL & Pr $>$ F & Termo de erro \\
\hline Dia & 3 & 0,01 & Vaca (dia) \\
Vaca (dia) & 8 & 0,01 & Resíduo \\
Tempo & 21 & 0,01 & Resíduo \\
Dia x tempo & 63 & 0,01 & Resíduo \\
\hline \hline
\end{tabular}

$* \mathrm{r}^{2}$ do modelo $=0,84$ 
Ocitocina; 50UI

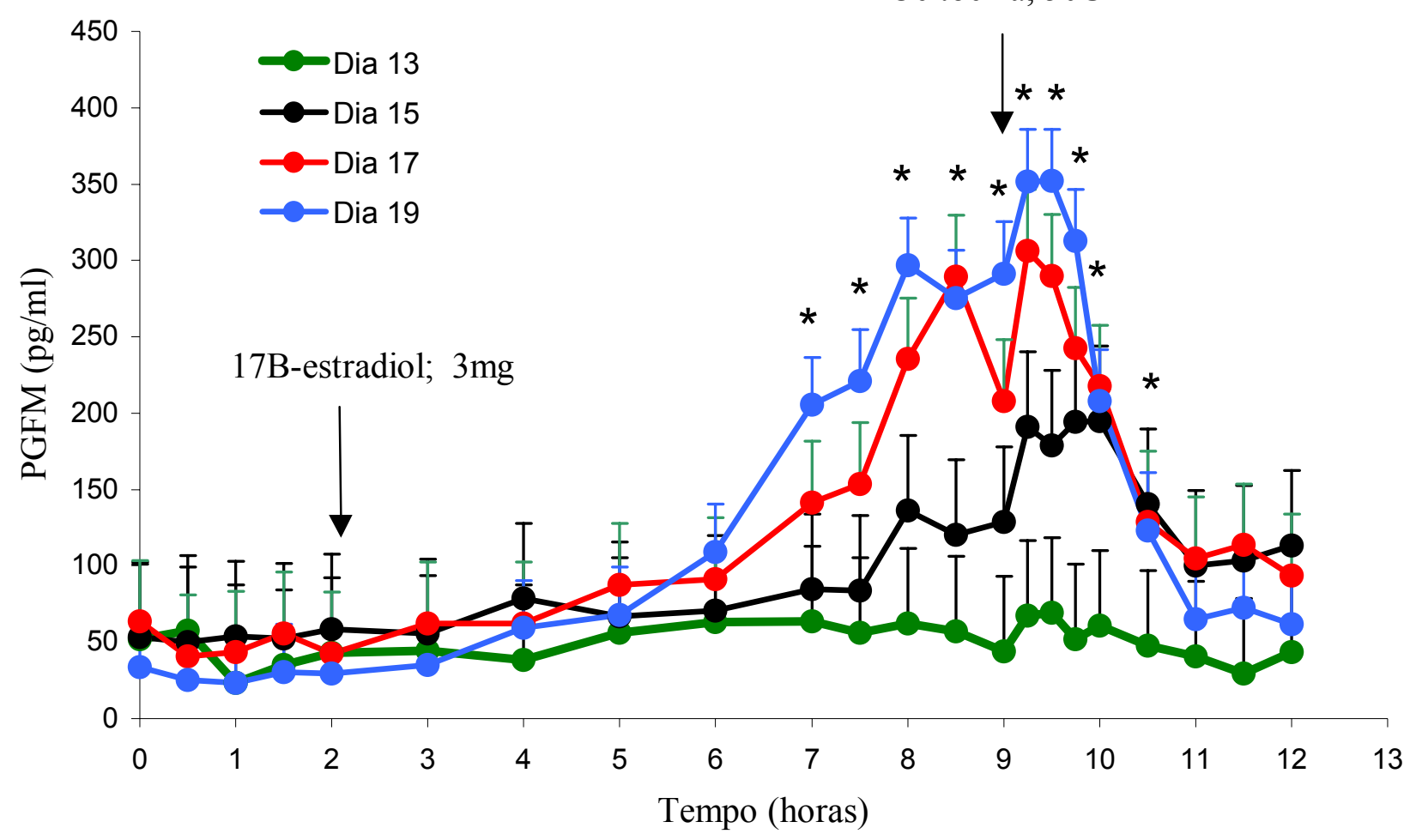

Gráfico 1 - Concentrações de PGFM das vacas tratadas com 17ß-estradiol (3mg; hora 2) e OT (50 UI; hora 9) nos dias $13(n=2), 15(n=2), 17(n=3)$ e $19(n=5)$ do ciclo estral - Pirassununga - Jun 2002

Valores não transformados; LSMeans \pm EPM

*Médias dos tratamentos em um mesmo tempo diferem estatísticamente $(\mathrm{P} \leq 0,05)$ 
Tabela 2 - Análise de variância dos quadrados mínimos das concentrações basais, pico - basal e pico/basal de PGFM em vacas nos dias $13(n=2), 15(n=2), 17(n=3)$ ou $19(n=5)$ do ciclo estral, submetidas ao tratamento com $3 \mathrm{mg}$ de $17 \beta$-estradiol - Pirassununga - Jun 2002

\begin{tabular}{lcc}
\hline \hline \multicolumn{1}{c}{ Variável independente: PGFM; pg/mL* } & \\
& $\mathrm{r}^{2}$ & $\operatorname{Pr} \geq \mathrm{F}$ \\
\hline \hline Concentração Basal (Concentração Basal) & 0,39 & 0,25 \\
Pico de secreção pós E 2 & 0,75 & 0,02 \\
Pico/ Concentração Basal & 0,2 & 0,64 \\
Pico - Concentração Basal & 0,75 & 0,03 \\
\hline \hline
\end{tabular}

*Dados transformados por Log; ver texto para definição das variáveis. 


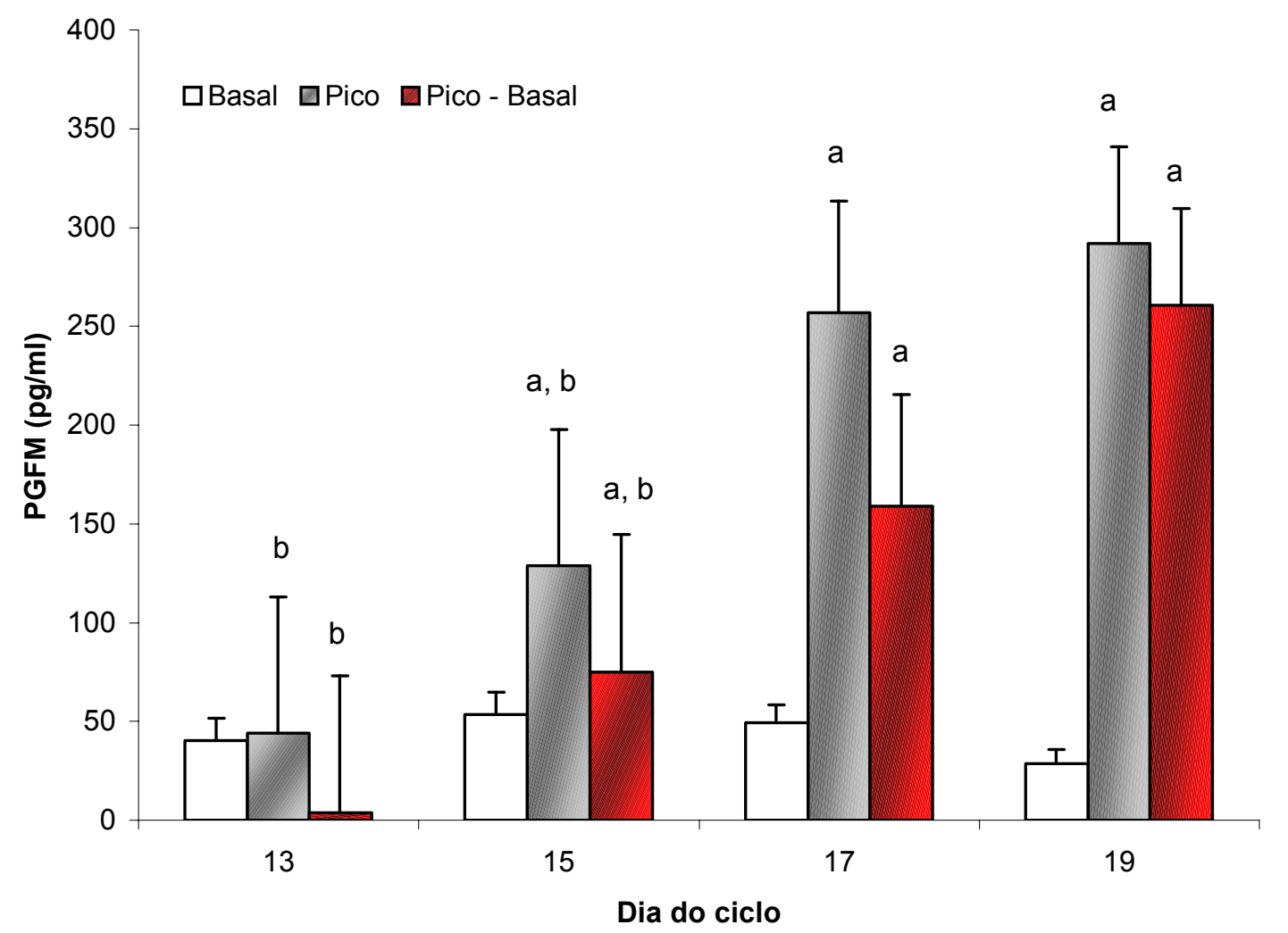

Gráfico 2 - Concentrações de basal, pico e diferença pico-basal de PGFM de vacas holandesas nos dias $13(n=2), 15(n=2), 17(n=3)$ e $19(n=5)$ do ciclo estral (ver texto) - Pirassununga - Jun 2002

Valores não transformados; LSMeans \pm EPM

a,b Cada variável dependente, designadas por letras diferentes diferem significativamente $(\mathrm{P} \leq 0.01)$ 
concentração não estimulada de PGFM não diferiu entre os diferentes dias do ciclo estral. Foi detectado efeito de dia para o pico de produção de PGFM e para a diferença da produção de pico e basal de PGFM que foi menor no D13 quando comparado ao D17 e D19 (P $\leq 0,01$; Tabela 2; Figura 2). Embora a diferença numérica tenha sido notável não foi possível determinar diferença estatística entre os dias 15, 17 e 19 para as variável Pico - Concentração Basal de PGFM. No presente estudo julgou-se que a variável diferença entre o pico e a concentração basal de PGFM é o melhor indicador da capacidade estimulatória do $\mathrm{E}_{2}$.

Após a injeção de $\mathrm{E}_{2}$ o pico das concentrações séricas de PGFM ocorreu com 6 a 6,5h e o retorno as concentrações basais $9 \mathrm{~h}$ após a administração de $\mathrm{E}_{2}$ para os animais tratados nos dias 15, 17 e 19 do ciclo estral. Relação temporal semelhante foi reportada por Thatcher et al. (1979) quando administraram $3 \mathrm{mg}$ de $17 \beta$-estradiol em 5 novilhas no $13^{\circ}$ dia do ciclo estral e observaram um aumento nas concentrações séricas de $E_{2}$ que teve início $3 h$ após a injeção, atingiu o pico com $6 \mathrm{~h}$ e com $9 \mathrm{~h}$ retornou as concentrações basais de PGFM. No presente estudo, verificou-se que a magnitude da resposta à injeção de $E_{2}$ foi progressivamente crescente ao longo do ciclo estral. Possivelmente, a ação do $\mathrm{E}_{2}$ em desencadear a síntese de PGF2 $\alpha$ é dependente de uma prévia e crescente sensibilização do endométrio por diversos fatores ao longo do ciclo estral.

Salfen et al. (1999) relataram que para a ocorrência da luteólise em fêmeas bovinas seriam pré-requisitos um período prévio de sensibilização do endométrio a $\mathrm{P}_{4}$ precedido por altas quantidades de $\mathrm{E}_{2}$, condições que se tornam cada vez mais propícias à medida que aumentam os dias ciclo estral no período que antecede a luteólise. Lafrance e Goff (1988) testaram os efeitos do $\mathrm{E}_{2}$ em fêmeas ovariectomizadas tratadas com $\mathrm{P}_{4}$ e sugeriram que um tratamento de no mínimo 14 dias com $\mathrm{P}_{4}$ e a exposição ao $\mathrm{E}_{2}$ são necessários para a ativação máxima do aparelho secretor de PGF2 $\alpha$. Considerando tais observações o endométrio de animais no $13^{\circ}$ dia do ciclo estral poderia não estar suficientemente sensibilizado pela $\mathrm{P}_{4}$ para 
que uma injeção de $E_{2}$ estimulasse a ativação máxima de PGF2 $\alpha$, condição que seria favorecida ao longo dos dias que antecedem a luteólise.

Também especula-se a participação do LH junto ao $\mathrm{E}_{2}$ na síntese de PGF2 $\alpha$, visto que Canino et al. (1999) realizaram um estudo com fêmeas bovinas ovariectomizadas pré-tratadas com $\mathrm{P}_{4}$, onde verificaram que injeções de $\mathrm{GnRH}$ (que promove um aumento de $\mathrm{LH}$ endógeno na corrente sanguínea) ou hCG (agonista do LH) 4 horas após a injeção de $\mathrm{E}_{2}$ potencializou a produção de PGFM em comparação aos animais que receberam somente $\mathrm{E}_{2}$. Estudos de Freidman, Gurevich e Shemesh (1995) ilustram tal hipótese quando constataram que os receptores de LH concentram-se no endométrio entre os dias 15 e 17 do ciclo estral, período que coincide com a luteólise. Imediatamente após a luteólise constatou-se o desaparecimento de tais receptores. Os mesmos autores verificaram por Western Blotting que o LH estimulou a síntese de COX-2, enzima responsável pela liberação do ácido araquidônico da membrana, principal precursor da PGF2 $\alpha$. No D13 do ciclo estral o CL ainda secreta quantidades máximas de $\mathrm{P}_{4}$ mantendo um padrão de liberação de LH típico da fase de diestro, entretanto, a medida que aumentam os dias do ciclo estral no período que antecede a luteólise as concentrações máximas de $\mathrm{P}_{4}$ não são mantidas, alterando o padrão da liberação de $\mathrm{LH}$, condição que favorece uma maior freqüência de pulsos de LH na corrente sangüínea com o objetivo de promover o crescimento final do folículo dominante. O aumento da freqüência de pulsos de LH poderia contribuir para a ativação dos receptores de LH no endométrio que junto ao $\mathrm{E}_{2}$ estimularia a síntese de PGF2 $\alpha$ endometrial.

No presente experimento a primeira amostra de cada animal teve a concentração plasmática de $\mathrm{P}_{4}$ mensurada e observou-se que em nenhum dos animais a luteólise fisiológica havia sido iniciada, pois caso contrário poderia ocasionar confundimentos nos resultados obtidos. 
Alguns estudos previamente realizados demonstraram que nem todas as fêmeas tratadas com $\mathrm{E}_{2}$ no $15^{\circ}$ dia do ciclo estral tiveram a síntese de PGFM estimulada e quando houve o estímulo nem sempre foi consistente (BERTHOLAZZI et al., 2003). No presente estudo, por homogeneidade das regressões, verificou-se que a produção de PGFM estimulada pelo $\mathrm{E}_{2}$ nos dias 17 e 19 foi maior comparada aos dias 13 e $15(\mathrm{P} \leq 0,01)$. Boos et al. (1996) verificaram que em ruminantes a concentração dos receptores de $\mathrm{E}_{2}$ e de $\mathrm{P}_{4}$ no epitélio uterino, estroma e miométrio variaram ao longo do ciclo estral em resposta às diferentes concentrações dos hormônios esteróides na circulação durante o ciclo estral. Alguns estudos verificaram que os receptores de $\mathrm{E}_{2}$ e $\mathrm{P}_{4}$ estão presentes em grandes concentrações na presença de concentrações plasmáticas altas de $\mathrm{E}_{2}$ associadas ao proestro e estro e decrescem na presença de altas concentrações de $\mathrm{P}_{4}$ (KATZENELLENBOGEN, 1980; LEAVITT et al., 1983; CLARK et al., 1995). Robinson et al. (2001) avaliaram a expressão do RNAm e a concentração dos receptores $\alpha$ de estrógeno no epitélio luminal e glândulas superficiais do endométrio e constataram uma variação ao longo do ciclo estral. A expressão de RNAm para o receptor de estrógeno foi alta durante o estro (D0) diminuiu no D2 e aumentou durante o início da fase luteal (D4 a D10). A menor expressão foi verificada no meio da fase luteal (D12 a D16), sendo o aumento na expressão retomado no D16. Essas evidências sugerem que antes do $16^{\circ}$ dia do ciclo estral o número insuficiente de receptores $\alpha$ para o estrógeno no endométrio poderia representar um fator limitante para que o mesmo estimulasse a síntese de PGF2 $\alpha$.

Embora Thatcher et al. (1979) tenham verificado um estímulo na síntese de PGFM em novilhas tratadas com $\mathrm{E}_{2}$ no $13^{\circ}$ dia do ciclo estral, no presente estudo tal estímulo não foi observado. A ausência do estímulo poderia ser pelo fato de no presente estudo as vacas terem recebido uma injeção de gonadorrelina, um GnRH sintético, no $6^{\circ}$ dia do ciclo estral com o intuito de promover a ovulação do folículo dominante e a determinação de um ciclo de três 
ondas em todas as fêmeas. Entretanto, a ovulação de tal folículo promoveu o desenvolvimento de um CL acessório e consequentemente um incremento nas concentrações plasmáticas de $\mathrm{P}_{4}$. Segundo Whates et al. (1996) e Ing, Tornesi (1997) na presença de altas concentrações de $\mathrm{P}_{4} \mathrm{a}$ expressão para os receptores de $\mathrm{E}_{2}$ é inibida, enquanto na presença de altas concentrações de $\mathrm{E}_{2}$ a expressão é estimulada, consequentemente a ausência do estímulo pode ter sido decorrente do número insuficiente de receptores para o $\mathrm{E}_{2}$ presentes no endométrio. Uma outra possibilidade, é que a resposta ao $\mathrm{E}_{2}$ pode ser dose dependente, onde em novilhas $3 \mathrm{mg}$ de $17 \beta$-estradiol no $13^{\circ}$ dia do ciclo estral seriam suficientes para promover um aumento nas concentrações de PGFM, enquanto em vacas haveria a necessidade de uma dose maior e/ou a resposta ao $\mathrm{E}_{2}$ pode ser dependente do estado fisiológico, onde novilhas seriam mais sensíveis ao tratamento com $\mathrm{E}_{2}$ comparadas às vacas.

No presente experimento a OT estimulou o aumento das concentrações séricas de PGFM no $15^{\circ}, 17^{\circ}$ e $19^{\circ}$ dia do ciclo estral exceto no $13^{\circ}$ dia do ciclo estral. É notável a diferença no intervalo de tempo requerido para a estimulação do $E_{2}$ e a da OT no aumento das concentrações de PGFM. A OT promove uma estimulação nos primeiros 30 minutos após a injeção da mesma, enquanto o $E_{2}$ requer aproximadamente 3 horas. Sugere-se que os mecanismos de ação do $\mathrm{E}_{2}$ e a da OT sejam completamente distintos. Possivelmente a OT atuaria por mecanismos não genômicos.

Embora haja algumas especulações sobre a atuação do $E_{2}$ na síntese de PGF2 $\alpha$, até o momento os mecanismos pelos quais tal atuação ocorre permanecem desconhecidos. A atuação do $E_{2}$ nas células endometriais poderia ocorrer por uma ação não genômica, que independeria da transcrição gênica, onde o $E_{2}$ ligado ao seu receptor atuaria na ativação de segundos mensageiros que ativariam a cascata geradora de PGF2 $\alpha$, sendo que por tal mecanismo os efeitos celulares seriam imediatos. Alguns estudos observaram que os efeitos imediatos do $17 \beta$-estradiol foram freqüentemente associados a um aumento da concentração 
de cálcio livre no citosol (PIETRAS; SZEGO, 1975; REVELLI; MASSOBRIO; TESARIK, 1998; STEFANO et al., 2000; ACCONCIA; MARINO, 2003). Um possível mecanismo de atuação do $\mathrm{E}_{2}$ seria a interação do $\mathrm{E}_{2}$ com moléculas envolvidas no aparelho gerador de PGF2 $\alpha$, para estimular a síntese da mesma, existe a possibilidade do $E_{2}$ estimular a produção de PGF2 $\alpha$ através da sua capacidade de ativação da PLC (WALKER; WESTON; HIXON, 1997). Contudo, levando-se em consideração o padrão temporal de resposta ao $E_{2}$ na produção de PGF2 $\alpha$ em fêmeas bovinas in vivo, onde a concentração de PGFM ocorreu 3 horas após a injeção de $\mathrm{E}_{2}$, sugere-se uma ação genômica. Nessa via, o complexo $\mathrm{E}_{2}$-receptor ativaria a transcrição gênica e a síntese de determinadas proteínas (GREENE; PRESS, 1986; LEUNG; WATHES, 2000; HO; LIAO, 2002). $\mathrm{O}_{2}$ poderia estimular a síntese de enzimas ou fatores de ativação das enzimas envolvidas na síntese de PGF2 $\alpha$ ou de receptores ou fatores ativadores de receptores para a ação de outros hormônios como OT, $\mathrm{P}_{4}$ ou LH. Recentemente, Acconcia a Marino (2003) verificaram haver um sinergismo entre a ação molecular genômica e não genômica do $\mathrm{E}_{2}$ induzindo a transcrição de genes.

Embora especulem-se os possíveis mecanismos pelos quais o $\mathrm{E}_{2}$ estimularia a síntese de PGF2 $\alpha$, tais mecanismos não foram determinados. Os experimentos 2, 3 e 4 da presente tese objetivaram colaborar para um melhor entendimento da atuação do $E_{2}$ na síntese de PGF2 $\alpha$ endometrial.

\subsection{CONCLUSÕES}

A resposta estimulatória à síntese de PGF2 $\alpha$ endometrial em fêmeas bovinas tratadas com $17 \beta$-estradiol foi crescente ao longo dos dias do ciclo estral. Considerando esses resultados, julgou-se o $17^{\circ}$ dia do ciclo estral o melhor dia para estudar as respostas in vivo e 
in vitro do endométrio a síntese PGF $2 \alpha$ pelo $\mathrm{E}_{2}$. No $17^{\circ}$ dia do ciclo estral a grande maioria dos animais é responsiva à injeção de $\mathrm{E}_{2} \mathrm{e}$ não iniciaram a luteólise fisiológica. 
5. EXPERIMENTO 2: EFEITOS DO ESTRADIOL NA PRODUÇÃO DE PGF2 $\alpha$ INDUZIDA POR ESTIMULADORES DA SÍNTESE DE PGF2 $\alpha$ EM EXPLANTES ENDOMETRIAIS 


\section{EXPERIMENTO 2: EFEITOS DO ESTRADIOL IN VIVO NA PRODUÇÃO DE PGF2 $\alpha$ INDUZIDA POR ESTIMULADORES EM EXPLANTES ENDOMETRIAIS}

\subsection{JUSTIFICATIVA}

A síntese de PGF2 $\alpha$ resulta de uma cascata de eventos intracelulares altamente coordenados, que envolve a ativação seqüencial de várias proteínas. A hipótese é que a produção de PGF2 $\alpha$ in vitro induzida por diferentes estimuladores é modulada pela administração de $\mathrm{E}_{2}$ in vivo que afeta diretamente os componentes envolvidos na cascata geradora de PGF2 $\alpha$, tais como a PLC, PKC e/ou PLA 2 , ou indiretamente, torne-os mais receptivos a posterior estimulação por outras moléculas para aumentar a produção de PGF2 $\alpha$.

O objetivo desse experimento foi comparar a capacidade de síntese de PGF2 $\alpha$ quando fragmentos endometriais oriundos de animais previamente injetados ou não com $17 \beta$-estradiol foram tratados com diferentes estimuladores intracelulares (ionóforo de cálcio, melitina ou OT) da cascata geradora de PGF2 $\alpha$. Tais estimuladores intracelulares agem em pontos específicos da cascata geradora de PGF2 $\alpha$, conforme representado na Figura 2. O ionóforo de cálcio (CI) aumenta a concentração de cálcio no citoplasma estimulando a PKC e a PLA2, a melitina age estimulando a enzima $\mathrm{PLA}_{2}$ e a OT estimula o início da cascata geradora de PGF2 $\alpha$ e o PDBu é um análogo do DAG, logo age estimulando PKC. 


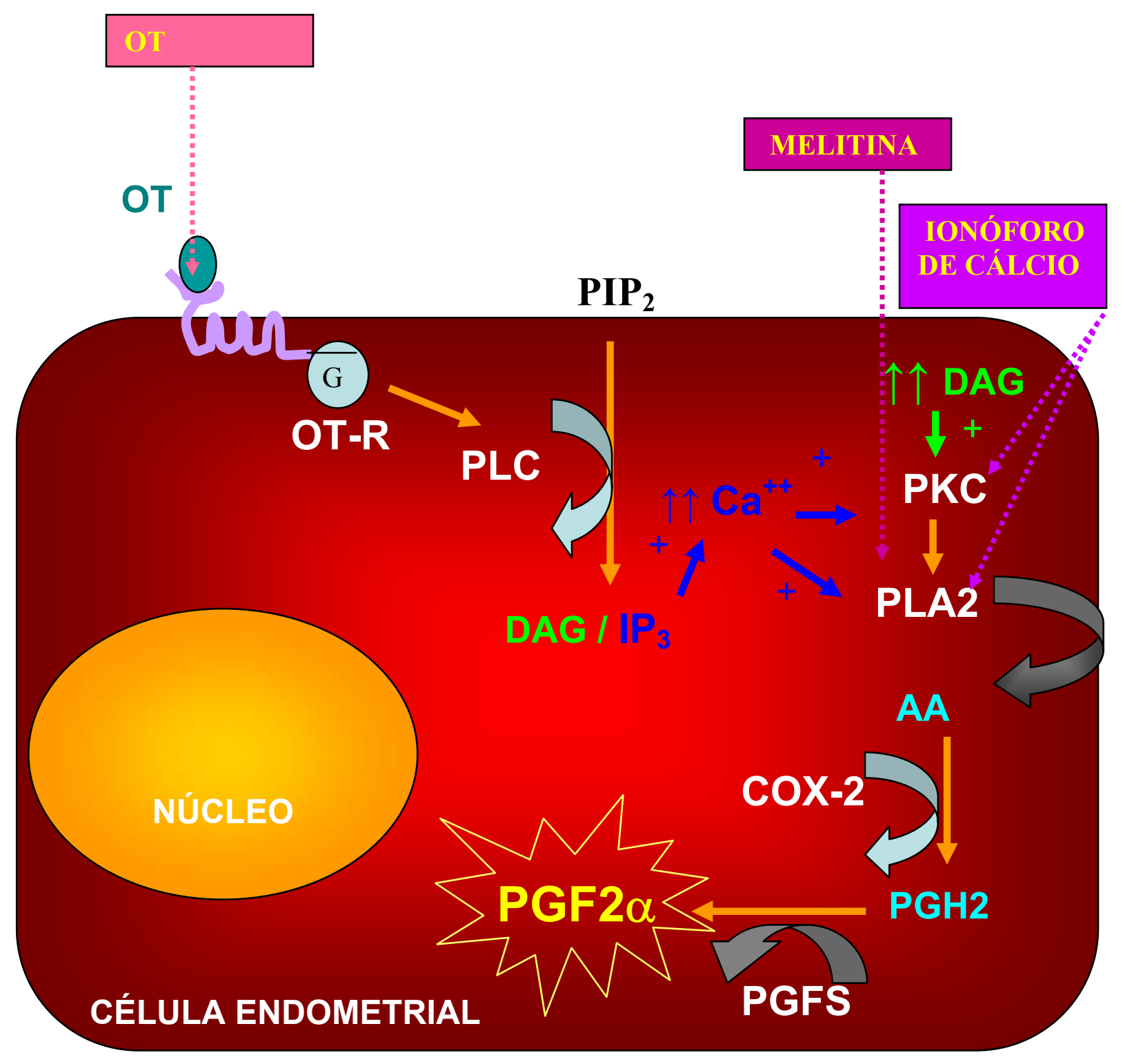

Figura 2 - Esquema ilustrando a biossíntese de PGF2 $\alpha$ a partir do ácido araquidônico proposto por Burns et al.. (1997) e o ponto de estimulação específico na cascata pelo cálcio ionóforo, melitina e ocitocia nas células endometriais bovinas 


\subsection{MATERIAL E MÉTODO}

Animais. Foram utilizadas 13 novilhas mestiças não gestantes (Bos taurus taurus $x$ Bos taurus indicus), de idade variável, não lactantes. Os animais foram mantidos em piquetes, com água à disposição. A alimentação foi baseada no pastejo (Brachiaria spp.) complementada por suplementação mineral. Na época da seca, foi realizada uma suplementação energética. Todos os animais foram vermifugados, vacinados e submetidos a exames para controle de tuberculose e brucelose.

Local do Experimento. O experimento foi realizado na Universidade de São Paulo, na Faculdade de Medicina Veterinária e Zootecnia, na cidade de Pirassununga - SP, nas dependências do Centro de Biotecnologia em Reprodução Animal, no Laboratório de Fisiologia e Endocrinologia Molecular (LFEM), no período de Janeiro/2002 a Dezembro/2003.

Delineamento Experimental. O método utilizado para a sincronização dos estros constituiu-se da implantação de dispositivos intravaginais contendo $\mathrm{P}_{4}$ (CIDR ${ }^{\circledR}$ - Pfizer) associados a uma injeção de $100 \mu \mathrm{g}$ de gonadorelina, um GnRH sintético (Fertagil ${ }^{\circledR}$ Intervet), sendo o dia da realização de tais procedimentos considerado o D0. A remoção do implante, realizada no D7, foi acompanhada de uma injeção de $150 \mu \mathrm{g}$ de D-cloprostenol (Preloban ${ }^{\circledR}$ - Intervet), um análogo sintético de PGF2 $\alpha$. No mesmo dia aplicou-se uma tinta marcadora na base da cauda das novilhas (All-Weather Paintstik ${ }^{\circledR}$, LA-CO Industries, Inc.), utilizada como um método auxiliar na detecção de estros. O comportamento de estro foi observado de 48 até 120 horas após a aplicação de PGF2 $\alpha$, a cada 12 horas, tendo sido considerado o dia do estro como o dia 0 do ciclo estral. No D6 do ciclo sincronizado os 
animais foram examinados por ultra-sonografia para a verificação da presença de um folículo com diâmetro $\geq 8 \mathrm{~mm}$. Havendo a presença de tal folículo, foi administrada uma injeção de $100 \mu \mathrm{g}$ de gonadorelina (Fertagil ${ }^{\circledR}$ - Intervet). O objetivo deste procedimento, foi induzir a ovulação do folículo dominante da primeira onda e ocasionar um ciclo estral de três ondas foliculares (DIAZ et al., 1998). Novo exame ultra-sonográfico foi realizado 48 horas após o tratamento com gonadorelina, para a verificação da ovulação do folículo dominante da primeira onda.

Para a realização dos estudos, novilhas foram pareadas de acordo com a data de apresentação de cio e no $17^{\circ}$ dia do ciclo estral foram injetadas com $0(n=6)$ ou $3 \mathrm{mg}(\mathrm{n}=7)$ de $\mathrm{E}_{2}$ e abatidas duas horas após. $\mathrm{O}$ abate foi realizado por concussão cerebral por pistola pneumática. Imediatamente após o abate, o sistema genital foi transportado ao laboratório a $4^{\circ} \mathrm{C}$. O endométrio do corno uterino ipsolateral ao CL foi dissecado e fragmentos da região intercaruncular de 80 a 100mg foram acondicionados em tubos de borosilicato de $12 \times 75 \mathrm{~mm}$ contendo $0,5 \mathrm{~mL}$ de meio bicarbonato Krebs-Hensleit (KHB; $118 \mathrm{mM} \mathrm{NaCl}, 4.7 \mathrm{mM} \mathrm{KCl}$, 2.56mM CaCl $2,1.13 \mathrm{mM} \mathrm{MgCl}_{2}, 25 \mathrm{mM} \mathrm{NaHCO} 3,1.15 \mathrm{mM} \mathrm{NaH}_{2} \mathrm{PO}_{4}, 5.55 \mathrm{mM}$ glucose, 20mM Hepes, e $0.013 \mathrm{mM}$ de vermelho fenol; $\mathrm{pH}$ 7.4). O cultivo dos explantes endometriais foi realizado conforme a técnica descrita por Burns et al. (1997; Anexo A4). Os tubos foram colocados em banho-maria a $37^{\circ} \mathrm{C}$ com agitação (40rpm) durante 1 hora. A seguir, descartouse o meio de cultura e lavaram-se os explantes duas vezes com KHB e adicionou-se $0,5 \mathrm{~mL}$ de KHB por tubo. Após nova incubação por uma hora, repetiu-se a lavagem. Em seguida, os fragmentos endometriais foram incubados em quadruplicata em $1 \mathrm{~mL}$ de meio KHB (controle) ou meio KHB suplementado com CI $10^{-5} \mathrm{M}$ (Sigma Chemicals C-7522; reconstituído em etanol na concentração de $1 \mathrm{mg} / \mathrm{mL}$ ), Melitina $10^{-5} \mathrm{M}$ (Sigma Chemicals M2272; reconstituída em etanol na concentração de $1 \mathrm{mg} / \mathrm{mL}$ ) ou OT $10^{-6} \mathrm{M}$ (Sigma Chemicals O-6379; reconstituída em solução de ácido acético 5\%, na concentração de $0,25 \mathrm{~g} / \mathrm{mL}$ ). As 
doses de CI (DANET-DESNOYERS et al., 1995; ARNOLD et al., 2000), melitina (BURNS et al., 1997; ARNOLD et al., 2000) e OT (BURNS et al., 1997; ARNOLD et al., 2000) foram baseadas em prévias publicações. Amostras de $100 \mu \mathrm{L}$ do meio de cultura foram removidas nos tempos 0 e 60 minutos após a adição dos tratamentos e armazenadas a $-20^{\circ} \mathrm{C}$ para a mensuração das concentrações de PGF2 $\alpha$, por radioimunoensaio. As concentrações de PGF2 $\alpha$ no meio de cultivo foram devidamente ajustadas para $\mathrm{pg} / \mathrm{ml} / \mathrm{mg}$ de tecido endometrial nos tempos 0 e 60 minutos. Todos os valores mensurados por radioimunoensaio menores que $5 \mathrm{pg} / \mathrm{mL}$ foram substituídos por $5 \mathrm{pg} / \mathrm{mL}$, visto ser a quantidade mínima de PGF2 $\alpha$ detectada no ensaio. A determinação da concentração de PGF2 $\alpha$ foi ajustada pelo volume aos 60 minutos. No minuto 0 havia $1 \mathrm{~mL}$ de meio de cultivo momento em que foi retirada uma amostra de $100 \mu \mathrm{L}$, restando no tubo apenas $900 \mu \mathrm{L}$, aos 60 minutos foi retirada outra amostra de $100 \mu \mathrm{L}$ coletada a partir de $90 \%$ do volume original $(900 \mu \mathrm{L} / 1000 \mu \mathrm{L})$, assim para ajustar a quantidade total de PGF2 $\alpha$ em $900 \mu \mathrm{L}$ adicionou-se $10 \%$ do total da concentração de PGF2 $\alpha$ presente o minuto 0 (exemplo: 0 minuto $=5 \mathrm{pg}$ em $1 \mathrm{~mL}$ de meio, 60 minutos $=25 \mathrm{pg} / \mathrm{mL}$ em $0,9 \mathrm{~mL}$ de meio; quantidade de PGF2 $\alpha$ ajustada aos 60 minutos $=25 \mathrm{pg} / \mathrm{mL}+[5 \mathrm{pg}$ x $0,10 \mathrm{~mL}]$ $=25,5 \mathrm{pg} / \mathrm{mL})$. Os coeficientes de variação intra-ensaio para a referência com baixa concentração $(250 \mathrm{pg} / \mathrm{mL})$ foi de $23,73 \%$ e para a referência com média $(1000 \mathrm{pg} / \mathrm{mL})$ concentração foi de $14,11 \%$. Os coeficientes de variação inter-ensaio para as referências de baixa e média concentração foram de $23,39 \%$ e $13,10 \%$, respectivamente.

Análise Estatística. Os dados foram analisados e não obedeceram as premissas quanto quanto à normalidade dos resíduos (Teste Shapiro-Wilk, $\mathrm{P} \leq 0,01$ ) e homogeneidade das variâncias (Teste $\mathrm{F}, \mathrm{P} \leq 0,01$ ). Os dados foram transformados por raiz quadrada e reanalisados. Tal transformação adequou os dados à análise de variância (Shapiro-Wilk e Teste F; $\mathrm{P} \geq 0,01$ ). A variável dependente foi a DIF 60 (diferença das concentrações de PGF2 $\alpha$ entre os tempos 0 
e 60 minutos) e as variáveis independentes foram: tratamento in vivo, animal (tratamento in vivo), tratamento in vitro e as interações tratamento in vivo $\mathrm{x}$ tratamento in vitro e tratamento in vitro $\mathrm{x}$ animal (tratamento in vivo). Os dados foram analisados por por ANOVA, utilizando-se o proc GLM do programa SAS (SAS Institute, 1988) e estão apresentados como LSmeans \pm EPM, não transformados. Cada um dos estimuladores foi comparado com o grupo controle (KHB) na presença ou ausência de $E_{2}$. As médias dos tratamentos foram comparadas por contrastes específicos.

\subsection{RESULTADOS E DISCUSSÃO}

Não houve efeito do tratamento in vivo com $\mathrm{E}_{2}$, entretanto, foi observado efeito do tratamento in vitro para o $\mathrm{CI}(\mathrm{P} \leq 0,01)$, melitina $(\mathrm{P} \leq 0,01)$ e a $\mathrm{OT}(\mathrm{P} \leq 0,01)$, conforme representado na Tabela 3. No presente estudo esperava-se que a síntese de PGF2 $\alpha$ ocasionada pelos diferentes estimuladores fosse amplificada quando o endométrio fosse previamente exposto ao tratamento in vivo com $\mathrm{E}_{2}$, efeito que não foi observado (interação in vivo vs. in vitro, $\mathrm{P} \geq 0,1)$.

A capacidade de tais estimuladores celulares em aumentarem a síntese de PGF2 $\alpha$ também foi observada em explantes endometriais de ovinos (LEE; SILVIA, 1994; BURNS et al., 2000) e bovinos (DANET-DESNOYERS et al., 1995; BURNS et al., 1997; BURNS; HAYES; SILVIA, 1998; SKARZYNSKI; BOGACKI; KOTWICA, 1999; MANN, 2001). Os diferentes estimuladores utilizados no presente experimento atuam em pontos específicos da cascata geradora de PGF2 $\alpha$. O CI promove o aumento das concentrações intracelulares de cálcio responsável pela ativação das enzimas PKC e PLA2. A ação da melitina compreende especificamente na ativação da PLA 2 . A ação da OT segundo Burns et al. (1997) consiste na ativação da fosfolipase C. 
Tabela 3 - Análise de variância dos quadrados mínimos da produção de PGF2 $\alpha$ (DIF 60) por explantes endometriais de vacas no $17^{\circ}$ dia do ciclo estral tratadas com $0(n=6)$ ou $3 \mathrm{mg}$ de $17 \beta$-estradiol $(\mathrm{n}=7)$ in vivo para testar o efeito do meio KHB suplementado com CI $10^{-5} \mathrm{M}$, Melitina $10^{-5} \mathrm{M}$ ou OT $10^{-6} \mathrm{M}$ pareados com o meio de cultivo KHB - Pirassununga - Jan. 2002 a Dez. 2003

\begin{tabular}{|c|c|c|c|c|}
\hline & $\operatorname{Pr}>\mathrm{F}$ & $\operatorname{Pr}>F$ & $\operatorname{Pr}>F$ & \\
\hline Fontes de variação & $\mathrm{Ca}^{++}$Íon. & Melitina & Ocit. & Termo de erro \\
\hline Trat. in vivo & 0,43 & 0,7 & 0,6 & An. (Trat.in vivo) \\
\hline Animal (Trat. in vivo) & 0,01 & 0,01 & 0,01 & Resíduo \\
\hline Trat. in vitro & 0,01 & 0,01 & 0,01 & Trat. in vitro $\mathrm{x}$ Animal (Trat. in vivo) \\
\hline Trat. in vivo $\mathrm{x}$ in vitro & 0,3 & 0,9 & 0,7 & Trat. in vitro $\mathrm{x}$ Animal (Trat. in vivo) \\
\hline Trat. in vitro $\mathrm{x}$ & 0,38 & 0,87 & 0,7 & Resíduo \\
\hline \multicolumn{5}{|l|}{ Animal (Trat. in vivo) } \\
\hline $\mathrm{R}^{2}$ & 0,58 & 0,56 & 0,59 & \\
\hline
\end{tabular}


Estudos realizados por Asselin et al. (1996) e Xiao et al. (1998) demonstraram que a adição de $\mathrm{E}_{2}$ ao meio de cultivo de explantes endometriais não estimulou a liberação de PGF2 $\alpha$, entretanto, Mann (2001) verificou um estímulo na secreção de PGF2 $\alpha$ em explantes endometriais bovinos quando foram cultivados in vitro com $\mathrm{E}_{2}$. Considerando a contrariedade dos dados reportados na literatura e o prévio conhecimento do comportamento das concentrações plasmáticas de PGFM em fêmeas tratadas com $\mathrm{E}_{2}$ no $17^{\circ}$ dia do ciclo estral (experimento 1 da presente tese), julgou-se apropriado no presente experimento a administração do $\mathrm{E}_{2}$ in vivo duas horas antes do abate das fêmeas.

No experimento 1 da presente tese observou-se após a administração de $17 \beta$-estradiol o pico das concentrações séricas de PGFM ocorreu com 6,5h e o retorno as concentrações basais $9 \mathrm{~h}$ após a administração de $\mathrm{E}_{2}$, relação temporal semelhante à reportada por Thatcher et al. (1986). No presente estudo, a administração de $\mathrm{E}_{2}$ foi realizada duas horas antes do abate, tendo sido requerido entre o processamento dos fragmentos endometrias, incubação, lavagem e administração dos tratamentos um período de aproximadamente 4,5 horas. Assim, os explantes endometriais foram incubados na presença dos diferentes estimuladores aproximadamente $6,5 \mathrm{~h}$ após a injeção de $\mathrm{E}_{2}$, período que coincidiu com a estimulação máxima promovida pelo $\mathrm{E}_{2}$ nos experimentos in vivo.

No presente estudo houve a expectativa de que o $\mathrm{E}_{2}$ estimularia a síntese de algumas proteínas envolvidas na cascata geradora de PGF2 $\alpha$, aumentando a concentração de tais proteínas no compartimento celular, e estas na presença do estimulador específico teria sua ação amplificada na síntese de PGF2 $\alpha$. O fato dos diferentes estimuladores agirem em pontos específicos da cascata indiciaria quais proteínas poderiam ter a síntese estimulada pelo $\mathrm{E}_{2}$. Quando os estimuladores foram analisados individualmente por contrastes ortogonais, verificou-se que nos explantes tratados com $\mathrm{CI}$ associado ao $\mathrm{E}_{2}$ a síntese de PGF2 $\alpha$ foi maior quando comparada ao grupo controle e aos tratamentos realizados exclusivamente com $\mathrm{E}_{2} \mathrm{ou}$ 
ionóforo de cálcio. Sugere-sea partir de tais resultados que a ação do $E_{2}$ na síntese de PGF2 $\alpha$ é dependente do ionóforo de cálcio, o mesmo efeito não observado para a melitina ou OT.

No presente estudo deve-se considerar que embora os explantes tenham sido expostos à presença dos estimuladores intracelulares por apenas 1 hora o endométrio havia sido previamente exposto ao $E_{2}$ por aproximadamente 6,5 horas, tempo suficiente para que o $E_{2}$ estimulasse a síntese de proteínas envolvidas na sua ação. Assim, tais proteínas na presença dos estimuladores intracelulares seriam ativadas resultando em um aumento na síntese de PGF2 $\alpha$, efeito que seria reconhecido pela diferença das concentrações de PGF2 $\alpha$ nas amostras coletadas com 0 e 60 minutos após a adição dos estimuladores intracelulares.

No presente experimento a DIF 60 para explantes tratados ou não com $\mathrm{E}_{2}$ e/ou CI, meltina ou OT foi ilustrada na Tabela 4 e Gráfico 3. 
Tabela 4 - Média dos quadrados mínimos da produção de PGF2 $\alpha$ (DIF 60) \pm SEM comparadas por contrastes ortogonais de explantes endometriais de vacas no $17^{\circ}$ dia do ciclo estral tratadas com $0(n=6)$ ou $3 \mathrm{mg}$ de $17 \beta$-estradiol $(n=7)$ tratados ou não in vitro com $\mathrm{CI} 10^{-5} \mathrm{M}$, Melitina $10^{-5} \mathrm{M}$ ou OT $10^{-6} \mathrm{M}$ Pirassununga - Jan. 2002 a Dez. 2003

$\begin{array}{llll}\text { Sem } \mathrm{E}_{2} \text { / sem tramento in vitro } & 24,65 \pm 4,6^{\mathrm{b}} & 24,65 \pm 4,6^{\mathrm{b}, \mathrm{e}} & 24,65 \pm 4,6^{\mathrm{b}} \\ \text { Sem } \mathrm{E}_{2} / \text { com tratamento in vitro } & 28,99 \pm 4,6^{\mathrm{b}} & 26,87 \pm 5,0^{\mathrm{a}, \mathrm{c}} & 28,23 \pm 4,6^{\mathrm{a}, \mathrm{b}, \mathrm{c}} \\ \text { Com } \mathrm{E}_{2} / \text { sem tramento in vitro } & 20,73 \pm 4,27^{\mathrm{b}} & 20,73 \pm 4,27^{\mathrm{b}, \mathrm{c}} & 20,73 \pm 4,27^{\mathrm{b}, \mathrm{c}} \\ \text { Com } \mathrm{E}_{2} / \text { com tramento in vitro } & 43,01 \pm 4,27^{\mathrm{a}} & 31,68 \pm 4,6^{\mathrm{a}, \mathrm{d}} & 33,15 \pm 4,27^{\mathrm{a}}\end{array}$

* Valores seguidos por letras diferentes pertencentes a uma mesma coluna diferem significativamente $(\mathrm{P} \leq 0,05)$ 

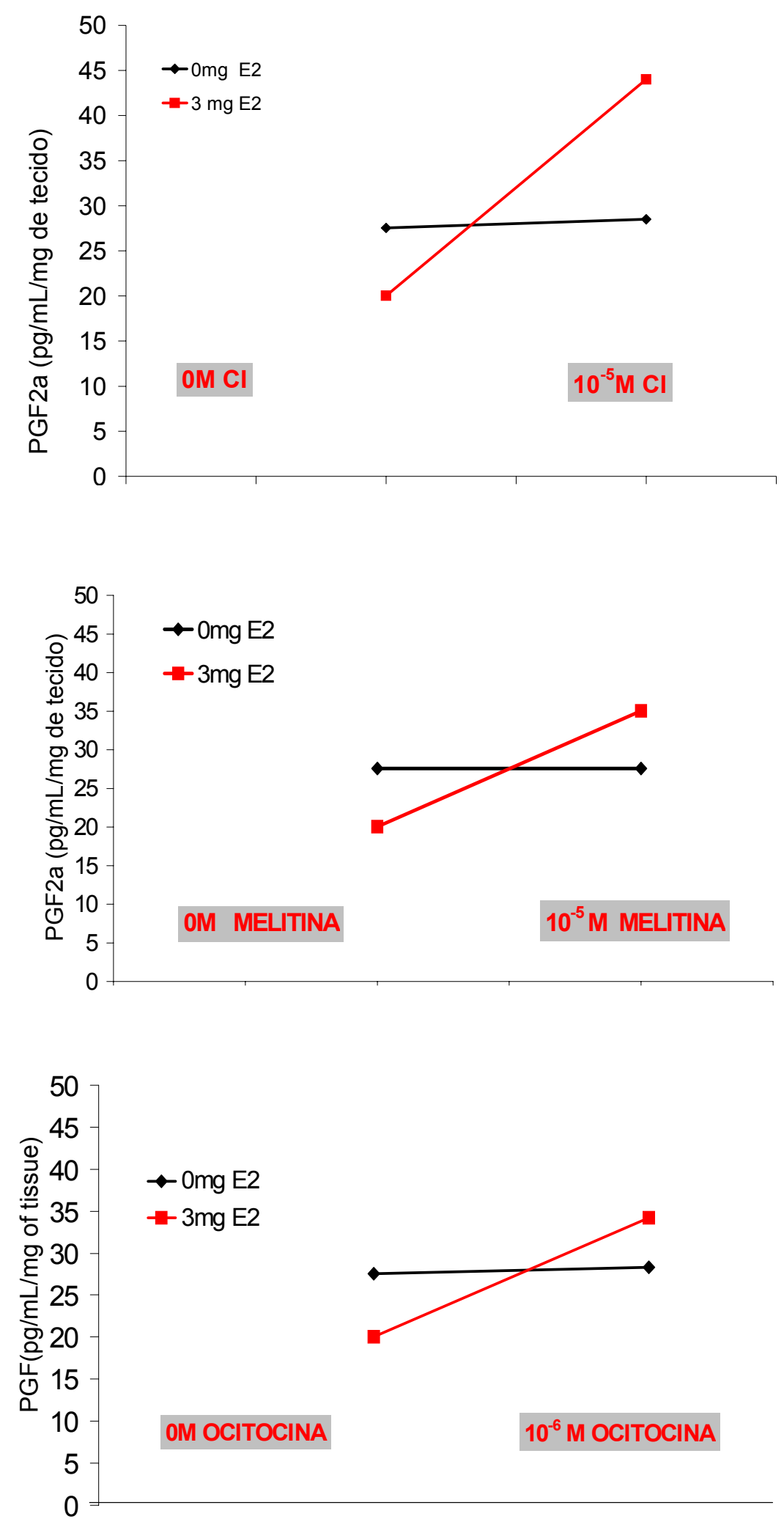

Gráfico 3 - Produção média de PGF2 $\alpha$ (DIF 60; LSmeans \pm EPM) de explantes endometriais de vacas no $17^{\circ}$ dia do ciclo estral tratadas com $0(n=6)$ ou $3 \mathrm{mg}$ de $17 \beta$ estradiol $(\mathrm{n}=7)$ tratados ou não in vitro com CI $10^{-5} \mathrm{M}$, Melitina $10^{-5} \mathrm{M}$ ou OT $10^{-6} \mathrm{M}$ - Pirassununga - Jan. 2002 a Dez. 2003 
No presente experimento explantes tratados com $\mathrm{E}_{2}$ e CI a DIF 60 foi maior quando comparada ao grupo controle $(\mathrm{P} \leq 0,01)$ e aos explantes tratados exclusivamente com CI $(P \leq 0,05)$ ou $E_{2} \quad(P \leq 0,01)$. A capacidade do $C I$ em estimular a secreção de PGF2 $\alpha$ no endométrio foi reportada em cobaias (POYSER, 1987), porcas (BASHA; BAZER; ROBERTS, 1980), ovelhas (SILVIA; HOMANICS, 1988; RAW; SILVIA, 1991; GRAF; BURNS; SILVIA, 1999) e vacas (DANET-DESNOYERS, 1995; BURNS; HAYES; SILVIA, 1998).

Burns, Hayes e Silvia (1998) relataram que no endométrio bovino a síntese de PGF2 $\alpha$ pode ser estimulada por uma grande variedade de agentes farmacológicos que promovem um acúmulo de cálcio no citoplasma como o CI A23187, a maitotoxina e a tapsigargina. O CI promove um influxo de cálcio do meio extracelular para o intracelular. Os mesmos autores também relatam agentes farmacológicos capazes de inibir o acúmulo de cálcio no citoplasma inibiram a síntese de PGF2 $\alpha$ estimulada pela OT no tecido endometrial.

No presente estudo a estimulação na síntese de PGF2 $\alpha$ pelo CI era esperada, pois o aumento nas concentrações citoplasmáticas de cálcio parece ser um componente essencial no mecanismo regulatório intracelular da síntese de PGF2 $\alpha$, uma vez que o cálcio atua como um cofator para as enzimas PKC e PLA 2 . Sugere-se a partir de tais resultados, que a PKC e a $\mathrm{PLA}_{2}$ estavam presentes em maiores concentrações nas células endometriais de fragmentos previamente tratados com $\mathrm{E}_{2}$ comparado aos não tratados. Tais enzimas, na presença do $\mathrm{CI}$, promoveram um aumento na síntese de PGF2 $\alpha$. Estudos de Burns, Hayes e Silvia (1998) testaram as doses de $10^{-9} \mathrm{M}$ a $10^{-5} \mathrm{M}$ de $\mathrm{CI}$ e verificaram que a menor dose capaz de promover o estímulo na síntese de PGF2 $\alpha$ foi $10^{-6} \mathrm{M}$, no presente estudo a dose de $10^{-5} \mathrm{M}$ não estimulou a síntese de PGF2 $\alpha$ em células endometriais tratadas exclusivamente CI, entretanto, a mesma dose associada ao $\mathrm{E}_{2}$ foi capaz de promover tal estímulo. 
A estrutura molecular das PKCs incluem regiões regulatórias e catalíticas. Segundo Srinivasan e Blundell (1997) a região regulatória é constituída por dois domínios designados de $\mathrm{C} 1$ e $\mathrm{C} 2$, sendo que nos isotipos de PKCs dependentes de cálcio o domínio C2 representa um sítio de ligação para o cálcio. A ativação da PKC requer a translocação da enzima inativa do citoplasma para a membrana da célula para a ativação da mesma pelo DAG e cálcio. A afinidade da PKC ao cálcio é grandemente aumentada pelo DAG. A forma inativa da PLA 2 localiza-se no citosol, entretanto, quando fosforilada na presença do cálcio, a PLA 2 torna-se ativada e transloca-se do citosol para o retículo endoplasmático ou membrana nuclear para promover a mobilização de AA (CHANON; LESLIE, 1990; CLARK et al., 1991). Concentrações altas de cálcio livre intracelular foram requeridas para promover a translocação da $\mathrm{PLA}_{2}$ do citosol para a membrana celular em tecido endometrial ovino (BURNS et al., 2000). Na presença do cálcio a $\mathrm{PLA}_{2}$ atinge sua ativação máxima quando há a fosforilação da serina 505, um substrato ativado pelas MAP quinases (GRAF; BURNS; SILVIA, 1999). No presente estudo o $E_{2}$ associado ao CI estimulou a síntese de PGF2 $\alpha$, sugerindo que o $E_{2}$ estimularia a síntese de proteínas ativadas pelo cálcio ( $\mathrm{PKC}$ e $\left.\mathrm{PLA}_{2}\right)$.

Lafrance e Goff (1990) não observaram o efeito estimulatório do CI na secreção de PGF2 $\alpha$ em explantes de novilhas nos dias 19 ou 20 do ciclo estral. Considerando que tal período compreenderia a luteólise fisiológica, provavelmente o efeito do CI não tenha sido observado por uma depleção nos estoques de PKC e PLA 2 nas células endometriais bovinas.

No presente experimento a DIF 60 para explantes tratados exclusivamente com melitina diferiu do grupo controle $(\mathrm{P} \leq 0,05)$, entretanto, quando a melitina foi associada ao $\mathrm{E}_{2}$ a DIF 60 foi maior que o grupo controle $(\mathrm{P} \leq 0,05)$ e para os explantes tratados exclusivamente com $\mathrm{E}_{2}(\mathrm{P} \leq 0,05)$. A capacidade da melitina em estimular a síntese de PGF2 $\alpha$ em explantes endometriais bovinos foi previamente reportada em cobaias (JOHNSON; POYSER, 1991), ovinos (LEE; SILVIA, 1994) e bovinos (BURNS et al., 1997; GRAF; BURNS; SILVIA, 
1999). Burns et al. (1997) relataram que a menor dose de melitina capaz de estimular a síntese de PGF2 $\alpha$ foi de $10^{-6} \mathrm{M}$, no presente estudo a dose de $10^{-5} \mathrm{M}$ foi capaz de promover tal estímulo quando comparada ao controle.

A PLA $_{2}$ é uma proteína de aproximadamente $85 \mathrm{kDa}$ constituída por uma cadeia polipeptídica simples, com 120 aminoácidos, contendo 10 a 14 cisteínas, que preferencialmente hidroliza o ácido araquidônico na posição sn-2 da fosfatidilcolina. A PLA 2 contém um domínio de ligação dependente de cálcio (NALEFSKI et al., 1994; SCHIEVELLA et al., 1995). Verificou-se que a ativação máxima da PLA 2 requer a fosforilação da serina 505 um substrato para a MAP quinase (LIN et al., 1993).

Em cultivo de células e explantes endometriais bovinos, tratados ou não com $E_{2}$, a ciclohexamida inibiu a síntese de PGF2 $\alpha$ (DA CUNHA, 2004). O aumento da síntese de PGF2 $\alpha$ também foi associado ao aumento da expressão de RNAm e da proteína PLA 2 (ZHANG; BRENNA; NATHANIEELSY, 1996). Possivelmente o $\mathrm{E}_{2}$ estimularia a síntese de $\mathrm{PLA}_{2}$, hipótese que parece ser sustentada no presente estudo.

No presente experimento a DIF 60 para explantes tratados com OT associada ao $\mathrm{E}_{2}$ foi maior que para o grupo controle $(\mathrm{P} \leq 0,01)$ e explantes tratados exclusivamente com $\mathrm{E}_{2}$ $(\mathrm{P} \leq 0,05)$, não tendo diferido dos explantes tratados exclusivamente com OT. Verificou-se que OT utilizada na ausência do prévio tratamento com $E_{2}$ não estimulou a síntese de PGF2 $\alpha$. Skarzynski, Bogacki e Kotwica (1999) também verificaram em explantes endometriais bovinos que a secreção de PGF2 $\alpha$ não foi estimulada pela OT após uma hora de cultivo, entretanto, tal estímulo foi observado com 24 horas de cultivo. No mesmo estudo quando células luteais foram associadas ao meio de cultivo contendo os explantes a produção máxima de PGF2 $\alpha$ foi observada após 12 horas de incubação e a PGF2 $\alpha$ secretada pelas células luteais representou $5 \%$ da mesma produzida pelo endométrio. Os mesmos autores sugerem que a $\mathrm{P}_{4}$ e/ou outros produtos luteais regulam a responsividade endometrial à $\mathrm{OT}$, afetando $\mathrm{o}$ 
desenvolvimento dos receptores de OT e/ou a formação de segundos mensageiros. Kombe, Sirois e Goff (2003) verificaram que o $E_{2}$ estimulou a síntese de PGF2 $\alpha$ aumentando o número de receptores de OT em células endometriais bovinas somente quando houve prévia exposição das mesmas à $\mathrm{P}_{4}$. Possivelmente os explantes provenientes de fêmeas no $17^{\circ}$ dia do ciclo estral haviam sido suficientemente expostos à $\mathrm{P}_{4}$ cumprindo tal pré-requisito para a ação do $\mathrm{E}_{2}$ em promover o aumento no número de receptores para a OT, para que a mesma pudesse estimular a síntese de PGF2 $\alpha$.

A OT estimulou a síntese de PGF2 $\alpha$ no útero bovino in vivo (LAFRANCE; GOFF, 1985; MANN; LAMMING, 1995; CASTRO E PAULA, 2003) e in vitro (LAFRANCE; GOFF, 1990; MIRANDO; BECKER; WHITEAKER, 1993; GRAF; BURNS; SILVIA, 1999). Demonstrou-se com uma série de estudos in vivo que o $\mathrm{E}_{2}$ é capaz de estimular a expressão dos receptores endometriais de OT (HIXON; FLINT, 1987; BEARD; LAMMING, 1994; SPENCER et al., 1995), mas ainda existe a possibilidade do $E_{2}$ exercer efeito na ativação de receptores de OT pré-existentes, e com isso potencializar a produção de PGF2 $\alpha$ estimulada pela OT (CASTRO E PAULA, 2003). De fato, os resultados observados no presente estudo demonstram a dependência da $\mathrm{OT}$ ao $\mathrm{E}_{2}$, visto que o estímulo na síntese de PGF2 $\alpha$ foi verificado somente quando a mesma foi associada ao $E_{2}$. Vários trabalhos hipotetizaram o mecanismo de ação da OT na síntese de PGF2 $\alpha$. A OT estimularia um rápido aumento da atividade de PLC (SILVIA; HOMANICS, 1988; VALLET; BAZER, 1989; WALLACE et al., 1993; LEE; SILVIA, 1994). Burns et al. (1997) relatam que a OT atuaria ativando a PLC clivando o fosfatidilinositol bifosfato em dois segundos mensageiros, o DAG e inositol trifosfato. O DAG poderia estimular a síntese de PGF2 $\alpha$ por uma das duas vias existentes: na primeira o DAG poderia servir como fonte de AA, o precursor da PGF2 $\alpha$, visto que o fosfatidilinositol contém uma grande quantidade de AA esterificado (HOLUB; CELI, 1984) e 
na segunda o DAG pode estimular a síntese de PGF2 $\alpha$ pelo aumento da atividade da PKC (NISHIZUKA et al., 1984).

Em outro estudo a OT induziu a síntese de PGF2 $\alpha$ pelo aumento das concentrações endometriais das MAP quinases fosforiladas p44 e p42, responsáveis pela fosforilação e aumento da atividade da $\mathrm{PLA}_{2}$ no citosol, assim, a OT atuaria aumentando a atividade da PLA $_{2}$ (BURNS et al., 2000; BURNS et al., 2001). Alguns estudos desenvolvidos com células endometriais de porcas tem atribuído a ação da OT na síntese de PGF2 $\alpha$ `a sua capacidade de mobilização de cálcio responsável pela ativação de PKC (HU; BRAILEANU; MIRANDO, 2001).

\subsection{CONCLUSÕES}

Explantes endometriais tratados in vitro com CI tiveram a síntese PGF2 $\alpha$ estimulada somente quando os explantes foram previamente tratados com $\mathrm{E}_{2}$ in vivo. Sugere-se que o $\mathrm{E}_{2}$ esteja envolvido na síntese de proteínas que participam da cascata geradora de PGF2 $\alpha$ dependentes de cálcio para sua ativação. 
6. EXPERIMENTO 3: SÍNTESE DE PGF2 $\alpha$ EM CÉLULAS ENDOMETRIAIS BOVINAS TRATADAS COM IONÓFORO DE CÁLCIO 


\section{EXPERIMENTO 3: SÍNTESE DE PGF2 $\alpha$ EM CÉLULAS ENDOMETRIAIS BOVINAS TRATADAS COM IONÓFORO DE CÁLCIO}

\subsection{JUSTIFICATIVA}

A tese proposta objetiva estudar os aspectos celulares e moleculares envolvidos na produção de PGF2 $\alpha$ estimulada pelo $\mathrm{E}_{2}$. Baseando-se na análise dos resultados obtidos no experimento 2, formulou-se a hipótese de que o $\mathrm{E}_{2}$ ativa a síntese de enzimas estimuladas pelo cálcio na liberação de PGF2 $\alpha$. Assim, julgou-se necessário um detalhamento no estudo da participação do $\mathrm{E}_{2}$ junto ao CI na síntese de PGF2 $\alpha$ endometrial, para tanto, foi validado um modelo de cultivo de células BEND.

O objetivo do presente experimento foi avaliar a capacidade do CI em estimular a síntese de PGF2 $\alpha$ em células BEND cultivadas e validar uma dose de CI adequada para promover tal estímulo, assim, células foram tratadas com CI em diferentes doses $\left(0,10^{-7}, 10^{-6}\right.$ ou $\left.10^{-5} \mathrm{M}\right)$. A hipótese é que o CI estimula a síntese de PGF2 $\alpha$ nas células BEND de forma dose dependente.

\subsection{MATERIAL E MÉTODO}

Local do Experimento. O cultivo de células BEND foi realizado no Laboratório de Morfo-Fisiologia Molecular e Desenvolvimento (LMMD), da Faculdade de Zootecnia e Engenharia de Alimentos da USP, no Campus de Pirassununga-SP, em colaboração com o Prof. Dr. Flávio Meirelles. As dosagens de PGF2 $\alpha$ foram realizadas na Universidade de São Paulo, na Faculdade de Medicina Veterinária e Zootecnia, na cidade de Pirassununga -SP, no 
Centro de Biotecnologia em Reprodução Animal, no Laboratório de Fisiologia e Endocrinologia Molecular, no período de Junho/2003 a Dezembro/2003.

Delineamento Experimental. Células BEND foram suspensas em meio de cultivo completo \{40\% HAM F-12 (Sigma N6760); 40\% de Minimal Essential Medium (MEM; Sigma M0643); 200IU de insulina/L (I5500); 10\% v/v de Soro Fetal Bovino (FBS; Gibco Life 10270-106); 10\% v/v de soro eqüino (Nutricel) e 1\% v/v de solução antibiótica e antimicótica

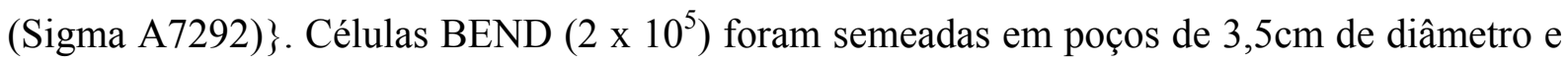
1,5cm de altura, em placas contendo seis cavidades (Costar 3516, Corning Incorporaed), em $4 \mathrm{~mL}$ meio de cultivo completo e cultivadas a $38,5^{\circ} \mathrm{C}$ em atmosfera umidificada contendo $5 \%$ de $\mathrm{CO}_{2}$, até atingirem confluência de $90 \%$. A seguir as células foram mantidas em meio sem soro por 24 horas, lavadas no mesmo meio duas vezes e incubadas por 12 horas em $4 \mathrm{~mL}$ de meio sem soro suplementado com $0,10^{-7}, 10^{-6}$ ou $10^{-5} \mathrm{M}$ de $\mathrm{CI}($ Sigma, C-7522), em triplicata (Anexo 6). Amostras de meio $(500 \mu \mathrm{L})$ foram colhidas nos tempos 0 e 12 horas de cultivo. Após a retirada de cada amostra no tempo 0, o mesmo volume de meio contendo o tratamento específico foi reposto. Essas amostras foram acondicionadas a $-20^{\circ} \mathrm{C}$ para posterior mensuração das concentrações de PGF2 $\alpha$ por radioimunoensaio (Anexo 5). Na técnica de radioimunoensaio os coeficientes de variação intra-ensaio para a referência com baixa concentração $(250 \mathrm{pg} / \mathrm{mL})$ foi de $13,18 \%$ e para a referência com média concentração (1000pg/mL) foi de $18,8 \%$. Os coeficientes de variação inter-ensaio para as referências de baixa e média concentração foram de $10,25 \%$ e $21,99 \%$, respectivamente. A quantidade de PGF2 $\alpha$ detectada no meio de cultivo foi ajustada considerando o volume de meio de cultivo retirado das cavidades nos diferentes tempos. Esse experimento foi repetido três vezes. 
Análise estatística. A concentração de PGF2 $\alpha$ produzidas nas primeiras 12 horas (DIF 12; concentração de PGF2 $\alpha$ com 12 horas de tratamento menos concentração de PGF2 $\alpha$ no tempo 0) foi a variável dependente. As variáveis independentes foram: repetição, tratamento e a interação repetição $\mathrm{x}$ tratamento. Demonstrou-se com uma análise preliminar que os dados de produção de PGF2 $\alpha$ (DIF 12) não estavam adequados quanto homogeneidade das variâncias (Teste $\mathrm{F}, \mathrm{P} \leq 0,01$ ). Os dados foram então transformados por raiz quadrada e reanalisados. Tal transformação adequou os dados à análise de variância (Shapiro-Wilk e Teste $\mathrm{F} ; \mathrm{P} \geq 0,01)$ os quais estão apresentados como LSmeans \pm EPM, não transformados. Os dados foram analisados por ANOVA, utilizando-se o proc GLM do programa SAS (SAS Institute, 1988). Os tratamentos foram comparados por contrastes ortogonais: $0 \mathrm{M}$ vs. $10^{-5} \mathrm{M}$, $10^{-6} \mathrm{M}, 10^{-7} \mathrm{M} ; 10^{-7} \mathrm{M}$ vs. $10^{-5} \mathrm{M}, 10^{-6} \mathrm{M}$ e $10^{-6} \mathrm{M}$ vs. $10^{-5} \mathrm{M}$.

\subsection{RESULTADOS E DISCUSSÃO}

As concentrações de PGF2 $\alpha$ produzidas nas primeiras 12 horas para as diferentes concentrações de CI estão representadas na Tabela 5 e Gráfico 4. No presente experimento foi evidenciada a capacidade estimulatória do CI na síntese de PGF2 $\alpha$ em células BEND quando foram utilizadas as doses de $10^{-6} \mathrm{M}$ e $10^{-5} \mathrm{M}$ de CI. Em experimentos preliminares (dados não apresentados) foram testadas também as doses de $10^{-8} \mathrm{M}$ e $10^{-9} \mathrm{M}$, entretanto, verificou-se que tais doses não estimularam a síntese de PGF2 $\alpha$, assim as mesmas não foram incluídas nesse experimento de validação de doses.

O CI estimulou a síntese de PGF2 $\alpha$ em todos os grupos tratados comparado ao controle $(\mathrm{P} \leq 0,01)$, entretanto nas doses de $10^{-6} \mathrm{M}$ e $10^{-5} \mathrm{M}$ o estímulo foi maior que para $10^{-7} \mathrm{M}$ $(\mathrm{P} \leq 0,01)$. Não houve diferença significativa entre as doses no $10^{-6} \mathrm{M}$ e $10^{-5} \mathrm{M}$. Assim, supõe-se que células BEND são estimuladas a sintetizar PGF2 $\alpha$ quando tratadas com doses $\leq 10^{-6} \mathrm{M}$. 
Tabela 5 - Análise de variância dos quadrados mínimos da produção de PGF2 $\alpha$ (DIF 12) em células BEND em meio de cultivo suplementado com $0 \mathrm{M}, 10^{-7} \mathrm{M}, 10^{-6} \mathrm{M}$ ou 105 M de CI- Pirassununga - Jun. 2003 a Dez. 2003

Fontes de variação

Repetição

Tratamento

Repetição x Tratamento
2

3

6
$\mathrm{P}$

0,02

0,01

0,05

$r^{2}=0,82$ 


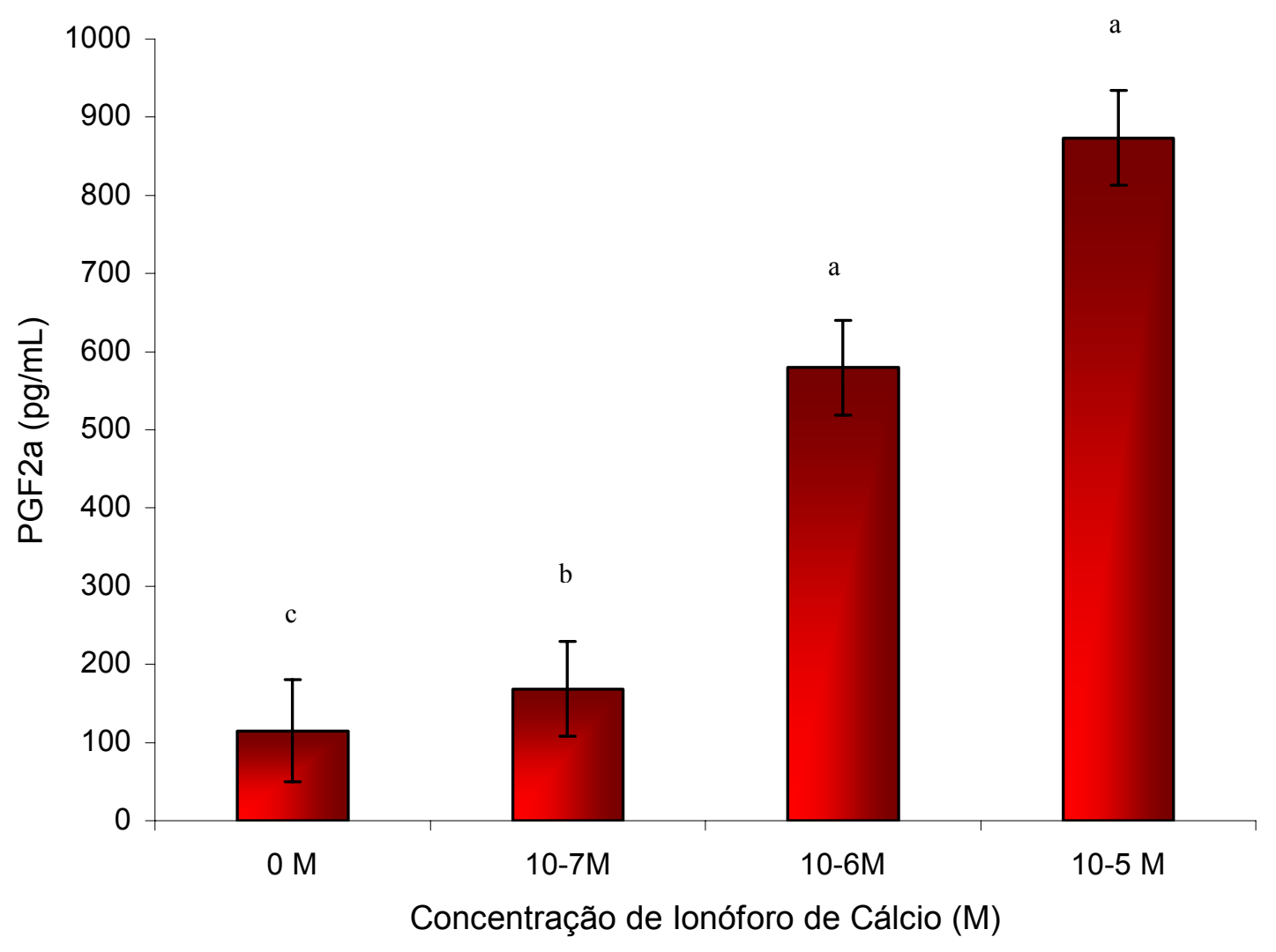

Gráfico 4 - Produção média (LSmeans \pm EPM) de PGF (pg/mL/mg de tecido) por células BEND tratadas com $0,10^{-7}, 10^{-6}$ ou $10^{-5} \mathrm{M}$ de CIpor 12 horas ${ }^{5} \mathrm{M}$ - Pirassununga Jun. 2003 a Dez. 2003

${ }^{* a, b, c}$ Barras designadas por letras diferentes diferem significativamente $(\mathrm{P} \leq 0,01)$ 
No presente experimento observou-se uma interação repetição $x$ tratamento $(P \leq 0,05)$, entretanto, quando as repetições foram observadas isoladamente o comportamento do CI quando utilizado nas diferentes doses foi muito semelhante em todas as repetições, entretanto, diferenças foram observadas quanto a magnitude das respostas.

Segundo Alberts et al. (1997) a concentração celular de cálcio livre no citosol é ao redor de $\leq 10^{-7} \mathrm{M}$, entretanto, concentrações de cálcio são maiores no líquido extracelular $\left(10^{-3} \mathrm{M}\right)$ e no retículo endoplasmático presente no compartimento celular. Tais concentrações diferenciais de cálcio favorecem um gradiente que tende a enviar cálcio do líquido extracelular para o citosol através da membrana plasmática e do retículo endoplasmático para o citosol através da membrana do retículo endoplasmático. Entretanto, para que o mecanismo de sinalização celular tendo o cálcio como segundo mensageiro funcione, a concentração basal de cálcio no citosol deve ser mantida baixa. Todas as células eucarióticas dispõem de mecanismos que garantem tal condição, pela presença de cálcio ATPase na membrana plasmática da célula e do retículo endoplasmático. A cálcio ATPase utiliza a energia proveniente da hidrólise do ATP para bombear cálcio para fora do citosol mantendo uma concentração de $\leq 10^{-7} \mathrm{M}$ no citosol quando a célula está em repouso. Quando a célula é ativada por um sinal extracelular a entrada de cálcio para o citosol, proveniente do líquido extracelular e retículo endoplasmático é favorecida atingindo uma concentração de aproximadamente $5 \times 10^{-6} \mathrm{M}$. Considerando tais observações, no presente experimento pretendeu-se determinar uma dose CI capaz de promover um aumento de cálcio no citosol das células BEND suficiente para desencadear um efeito intracelular, no caso estimular a síntese de PGF2 $\alpha$. Nesse experimento a síntese de PGF2 $\alpha$ foi efetivamente estimulada com a dose de $10^{-6}$ e $10^{-5} \mathrm{M}$ de CI.

No modelo celular descrito por Burns et al. (1997) que se refere à síntese de PGF2 $\alpha$ em células endometriais, o fosfoinositídeo $\mathrm{PIP}_{2}$, presente na parede interna da dupla camada 
lipídica que compõe a membrana celular, é degrado originando $\mathrm{DAG}$ e $\mathrm{IP}_{3}$. $\mathrm{O} \mathrm{IP}_{3}$ é uma pequena molécula, altamente solúvel em água, que após ser liberada da membrana plasmática se difunde rapidamente pelo citosol. $\mathrm{O} \mathrm{IP}_{3}$ liga-se a canais liberadores de cálcio presentes na membrana do retículo endoplasmático promovendo a saída de cálcio para o citosol. Tais canais são regulados por um mecanismo de retroalimentação positiva, onde o cálcio liberado pode ligar-se novamente aos canais aumentando ainda mais a liberação de cálcio. Nesse modelo, o cálcio seria responsável pela ativação das enzimas PKC e PLA 2 , fundamentais para a síntese de PGF2 $\alpha$ pelas células endometriais. Dois mecanismos funcionam para finalizar a resposta inicial do cálcio, possibilitando que a concentração de cálcio no citosol retorne a concentração $\leq 10^{-7} \mathrm{M}$. O $\mathrm{IP}_{3}$ é rapidamente desfosforilado por fosfatases específicas e consequentemente inativado e o cálcio excedente no citosol é rapidamente bombeado, principalmente para fora da célula. Segundo Alberts et al. (1997), os ionóforos são pequenas moléculas hidrofóbicas que se dissolvem em bicamadas lipídicas da membrana plasmática e aumentam sua permeabilidade a íons orgânicos específicos. Existem duas classes de ionóforos, os carreadores iônicos e os formadores de canais, ambos os tipos isolam a carga elétrica dos íons transportados, permitindo a entrada do mesmo no interior hidrofóbico da bicamada lipídica. O CI utilizado no presente experimento é um carreador iônico que transporta cálcio, atuando como um transportador trocador de íons, carregando dois íons $\mathrm{H}^{+}$ para fora da célula para cada íon cálcio transportado para dentro das células. Quando as células são expostas ao CI, o cálcio presente no líquido extracelular entra no citosol a favor de um forte gradiente eletroquímico, possibilitando um aumento de cálcio livre no citosol. Considerando a capacidade de células BEND em sintetizarem PGF2 $\alpha$ (BINELLI et al., 2000; GUZELOGLU et al., 2004), no presente experimento o CI favoreceria a ativação das enzimas PKC e PLA 2 em tais células contribuindo para uma maior estimulação na síntese de PGF2 $\alpha$, efeito que foi observado. Até o momento, o CI ainda não havia sido utilizado como 
estimulador intracelular em células BEND, apenas em explantes endometriais, onde também foi capaz de estimular a síntese de PGF $2 \alpha$ na presença de doses $\leq 10^{-6} \mathrm{M}$ (BURNS; HAYES; SILVIA, 1998), mesma dose relatada como sendo efetivamente eficiente para estimular a síntese de PGF2 $\alpha$ no presente experimento. Tais resultados realçam a similaridade fisiológica e endocrinológica entre os modelos experimentais de cultivo de explantes endometriais e cultivo de células endometriais BEND.

Os primeiros estudos realizados com o CI para avaliar sua capacidade em estimular a síntese de PGF2 $\alpha$ foram realizados com o endométrio de porcas (BASHA; BAZER; ROBERTS, 1980), cobaias (POYSER, 1987; RILEY; POYSER, 1987) e ovelhas (RAW; SILVIA, 1991; SILVIA; HOMANICS, 1988; SILVIA et al., 1994). Riley e Poyser (1987) reportaram um aumento na síntese de PGF2 $\alpha$ no endométrio de cobaias quando expostos ao CI. Os mesmos autores ainda reportaram que o CI aumentou a quantidade de íons cálcio que atravessaram a membrana plasmática promovendo um aumento da concentração de cálcio no citosol capaz de estimular a biossíntese de PGF2 $\alpha$. Posteriormente, o efeito estimulatório do CI na síntese de PGF2 $\alpha$ também foi evidenciado em explantes endometriais de fêmeas bovinas (DANET-DESNOYERS et al., 1995; TYSSELING et al., 1998; ARNOLD et al., 2000; experimento 2 da presente tese). Em outros estudos a tapsigargia, um potente inibidor da atividade cálcio APTase, estimulou a síntese de PGF2 $\alpha$ em explantes endometriais bovinos (TYSSELING et al., 1998; BURNS; HAYES; SILVIA, 1998) e células endometriais de porcas (HU et al., 2001).

No presente estudo o CI estimulou a síntese de PGF2 $\alpha$ em células BEND de forma dose dependente, pois a produção de PGF2 $\alpha$ foi crescente a medida que a dose do mesmo foi aumentada, onde doses de $10^{-6}$ e $10^{-5} \mathrm{M}$ estimularam de maneira efetiva a síntese de PGF2 $\alpha$.

Danet-Desnoyers et al. (1995) relataram que o CI estimulou a biossíntese de PGF2 $\alpha$ no endométrio de vacas no $17^{\circ}$ dia do ciclo estral e que tal resposta foi dose dependente, 
sendo secreção de PGF2 $\alpha$ incrementada em 0, 67 e 107\% para as doses de 2, 4 e $10 \mu \mathrm{g} / \mathrm{mL}$, respectivamente. No presente experimento foram utilizadas as doses de $0,052 \mu \mathrm{g} / \mathrm{mL}\left(10^{-7} \mathrm{M}\right)$, $0,52 \mu \mathrm{g} / \mathrm{mL}\left(10^{-6} \mathrm{M}\right)$, e $5,2 \mu \mathrm{g} / \mathrm{mL}\left(10^{-5} \mathrm{M}\right)$ que contribuíram para um incremento na produção de PGF2 $\alpha$ comparadas ao grupo controle de 46, 405 e $661 \%$, respectivamente. Lafrance e Goff (1990) observaram que $2,6 \mu \mathrm{g} / \mathrm{mL}$ de CI foi insuficiente para estimular a síntese de PGF2 $\alpha$ em explantes endometriais de novilhas nos dias 19 ou 20 do ciclo estral. Tais observações sugerem que células BEND seria mais sensíveis ao tratamento com CI quando comparadas a explantes endometriais, ou seja, em células BEND menores doses de CI estimulariam a síntese de PGF2 $\alpha$ com uma resposta de maior amplitude comparado aos explantes endometriais. Entretanto, Burns, Hayes e Silvia (1998) realizaram um estudo para determinar a dose de CI capaz de promover um influxo de cálcio do meio extracelular para o citosol em quantidade suficiente para estimular a síntese de PGF2 $\alpha$ em explantes endometriais cultivados in vitro. Tal estudo verificou que a menor concentração capaz de promover tal estímulo foi $10^{-6} \mathrm{M}$, resultado semelhante ao observado no presente estudo.

O aumento das concentrações intracelulares de cálcio está envolvida na ativação da PLA $_{2}$ (VAN DEN BOSCH, 1980; HO; KLEIN, 1987) e consequentemente no aumento da disponibilidade do AA para a síntese de PGF2 $\alpha$ (VAN DEN BOSCH, 1980). Arnold et al. (2000) verificaram que no endométrio de vacas cíclicas, a adição de CI ao meio de cultivo estimulou a síntese de PGF2 $\alpha$ em meios suplementados ou não com PLA 2 . No mesmo estudo a adição de $\mathrm{PLA}_{2}$ e CI estimulou mais a secreção de PGF2 $\alpha$ no endométrio do que quando tratados somente com $\mathrm{PLA}_{2}$. Isso sugere que o cálcio causa um efeito aditivo a $\mathrm{PLA}_{2} \mathrm{em}$ estimular a síntese de PGF2 $\alpha$. Além disso, relata-se que o aumento de cálcio é imprescíndivel para a ativação máxima da PLA $_{2}$, que requer a fosforilação da serina 505 (VOGT, 1978; SCHREY; RUBIN, 1979). 
Uma segunda enzima envolvida na síntese de PGF2 $\alpha$ estimulada pelo cálcio é a PKC. Guzeloglu et al. (2004) analizaram os isotipos de PKC presentes em células BEND e identificaram por Western Blotting a presença dos isotipos $\alpha, \varepsilon, \imath$ e $\lambda$. Os mesmos autores relatam que os outros isotipos são expressos em níveis muito baixos, e os anticorpos não foram capazes de detectar ou os anticorpos de PKC obtidos de camundongos não foram reconhecidos pelos isotipos de PKC de bovinos. Houve a predominância do isotipo $\alpha$ no citoplasma. Segundo Hofmann (1997) a família PKC podem ser dividida em subtipos: A) PKC Clássicas ou Convencionais, dependentes de cálcio e fosfolipídeos para sua ativação; B) Novas PKCs que não requerem cálcio para a ativação embora possuam um domínio para o cálcio e C) PKCs Atípicas que não são dependentes de cálcio e fosfolípideos para sua ativação. $\mathrm{O}$ isotipo $\alpha$ é dependente de cálcio e fosfolipídeos para a ativação, o isotipo $\varepsilon$ não requer cálcio para ativação embora possua um domínio para tal e os isotipos 1 e $\lambda$ não são dependentes de cálcio. Contudo, Alberts et al. (1997) relatam a degradação do $\mathrm{PIP}_{2}$ a $\mathrm{IP}_{3}$ e a DAG é realizada pela PKC isotipo $\beta$, dependente de cálcio e fosfolipídos para sua ativação, entretanto, tal isotipo não foi identificado em células BEND (GUZELOGLU et al., 2004). Hu et al (2001) utilizando inibidores espécificos para as diferentes isoformas de PKC verificaram que PKC $\alpha, \mathrm{PKC} \beta \mathrm{II}, \mathrm{PKC} \gamma$ e PKCE estavam presentes em células epiteliais luminais do endométrio. Considerando que em células BEND predomina PKC $\alpha$ e esta é dependente de cálcio para sua ativação, o estímulo a produção de PGF2 $\alpha$ pelo CI em parte possa ser atribuída ao favorecimento da ativação de PKC $\alpha$.

O experimento realizado demonstrou que células endometriais cultivadas em meio suplementado com CI em dose $\leq 10^{-6} \mathrm{M}$ apresentaram a capacidade de síntese de PGF2 $\alpha$ aumentada. O CI poderia estimular PKC e $\mathrm{PLA}_{2}$ ou diretamente a $\mathrm{PLA}_{2}$ na ausência da ativação de PKC. 


\subsection{CONCLUSÕES}

O CI estimula a síntese de PGF2 $\alpha$ nas células BEND de forma dose dependente, quando adicionado ao meio de cultivo por 12 horas. 
7. EXPERIMENTO 4: SÍNTESE DE PGF2 $\alpha$ EM CÉLULAS ENDOMETRIAIS BOVINAS TRATADAS COM IONÓFORO DE CÁLCIO E ESTRADIOL 


\section{EXPERIMENTO 4: SÍNTESE DE PGF2 $\alpha$ EM CÉLULAS ENDOMETRIAIS BOVINAS TRATADAS COM IONÓFORO DE CÁLCIO ESTRADIOL}

\subsection{JUSTIFICATIVA}

O objetivo desse experimento foi avaliar a capacidade de células BEND em sintetizarem PGF2 $\alpha$ quando tratadas com $\mathrm{CI}$ e $\mathrm{E}_{2}$. A hipótese é que o $\mathrm{E}_{2}$ aumenta a sensibilidade das células endometriais à ação do cálcio.

\subsection{MATERIAL E MÉTODO}

Local do Experimento. O cultivo de células endometriais foi realizado no Laboratório de Morfo-Fisiologia Molecular e Desenvolvimento (LMMD), da Faculdade de Zootecnia e Engenharia de Alimentos da USP, no Campus de Pirassununga-SP, em colaboração com o Prof. Dr. Flávio Meirelles. As dosagens de PGF2 $\alpha$ foram realizadas na Universidade de São Paulo, na Faculdade de Medicina Veterinária e Zootecnia, na cidade de Pirassununga -SP, no Centro de Biotecnologia em Reprodução Animal, no Laboratório de Fisiologia e Endocrinologia Molecular, no período de Janeiro/2004 a Abril/2004.

Delineamento Experimental. Células BEND $\left(4 \times 10^{4}\right)$ foram semeadas em poços de 1,5cm de diâmetro e $2 \mathrm{~cm}$ de altura, em placas de 24 poços (Costar, Corning Incorporated), em $1,5 \mathrm{~mL}$ de meio de cultivo completo e cultivadas a $38,5^{\circ} \mathrm{C}$ em atmosfera umidificada contendo $5 \%$ de $\mathrm{CO}_{2}$, até atingirem uma confluência de $90 \%$. As células foram a seguir mantidas em meio sem soro por 24 horas, lavadas no mesmo meio duas vezes e incubadas por 12 horas em $1,5 \mathrm{~mL}$ de meio sem soro suplementado com 0 ou $10^{-13} \mathrm{M} \mathrm{E}_{2}$ (Sigma, E-8875; a dose utilizada foi determinada em estudos preliminares; dados não apresentados) e 0 ou $10^{-6} \mathrm{M} \mathrm{CI}$ de CI 
(Sigma, C-7522), em um arranjo fatorial 2 x 2, em triplicata (Anexo 6). Amostras de meio $(300 \mu \mathrm{L})$ foram colhidas nos tempos 0 e 12 horas de cultivo. Após a retirada de cada amostra no tempo 0, o mesmo volume de meio contendo o tratamento específico foi reposto. Essas amostras foram acondicionadas a $-20^{\circ} \mathrm{C}$ para posterior mensuração das concentrações de PGF2 $\alpha$ por radioimunoensaio (Anexo 5). Esse experimento foi repetido três vezes. Na técnica de radioimunoensaio os coeficientes de variação intra-ensaio para a referência com baixa concentração $(250 \mathrm{pg} / \mathrm{mL})$ foi de $16,0 \%$ e para a referência com média concentração (1000pg/mL) foi de 20,63\%. Os coeficientes de variação inter-ensaio para as referências de baixa e média concentração foram de 3,97\% e 18,92\%, respectivamente. A quantidade de PGF2 $\alpha$ detectada no meio de cultivo foi ajustada considerando o volume de meio de cultivo retirado das cavidades nos diferentes tempos.

Análise estatística. A concentração de PGF2 $\alpha$ produzida nas primeiras 12 horas (DIF 12; concentração de PGF2 $\alpha$ com 12 horas de tratamento menos concentração de PGF2 $\alpha$ no tempo 0) foi a variável dependente. As variáveis independentes foram: repetição, tratamento e a interação repetição x tratamento. Demonstrou-se com uma análise preliminar que os dados não estavam adequados quanto à normalidade dos resíduos (Teste Shapiro-Wilk, $\mathrm{P} \leq 0,01)$ e homogeneidade das variâncias (Teste $\mathrm{F}, \mathrm{P} \leq 0,01$ ). Os dados foram então transformados por raiz quadrada e reanalisados. Tal transformação adequou os dados à análise de variância (Shapiro-Wilk e Teste F; P $\geq 0,01$ ) os quais estão apresentados como LSmeans \pm EPM, não transformados. Os dados foram analisados por ANOVA, utilizando-se o proc GLM do programa SAS (SAS Institute, 1988). Os tratamentos foram comparados por contrastes ortogonais. 


\subsection{RESULTADOS E DISCUSSÃO}

Foi observado efeito de tratamento $(\mathrm{P}<0,01)$, conforme representado na Tabela 6 e Gráfico 5. O tratamento com $\mathrm{E}_{2}$ associado ao CI estimulou uma maior síntese de PGF2 $\alpha$ nas células BEND comparado aos outros tratamentos. Em células tratadas exclusivamente com CI houve uma tendência $(\mathrm{P} \leq 0,08)$ da síntese de $\mathrm{PGF} 2 \alpha$ ser maior que nas células controles e tratadas somente com $\mathrm{E}_{2}$.

$\mathrm{O}$ tratamento com $\mathrm{E}_{2}$ exclusivamente não estimulou a síntese de PGF2 $\alpha$ comparado ao grupo controle. O CI foi responsável por um incremento de $179 \%$ na produção de PGF2 $\alpha$ comparado ao grupo controle, entretanto, quando foi associado ao $\mathrm{E}_{2} \mathrm{o}$ incremento foi de $340 \%$ comparado ao grupo controle e de $58 \%$ comparado ao grupo tratado exclusivamente com CI. Assim, notavelmente o $\mathrm{E}_{2}$ aumentou a sensibilidade das células endometriais à ação do cálcio. 
Tabela 6 - Análise de variância dos quadrados mínimos da produção de PGF2 $\alpha$ (DIF 12) em células BEND tratadas com em meio de cultivo suplementado com $0 \mathrm{M}$ ou $10^{-13} \mathrm{M}$ de $\mathrm{E}_{2}$ associados a $0 \mathrm{M}$ ou, $10^{-6} \mathrm{M}$ de CI - Pirassununga - Jan. 2004 a Abr. 2004

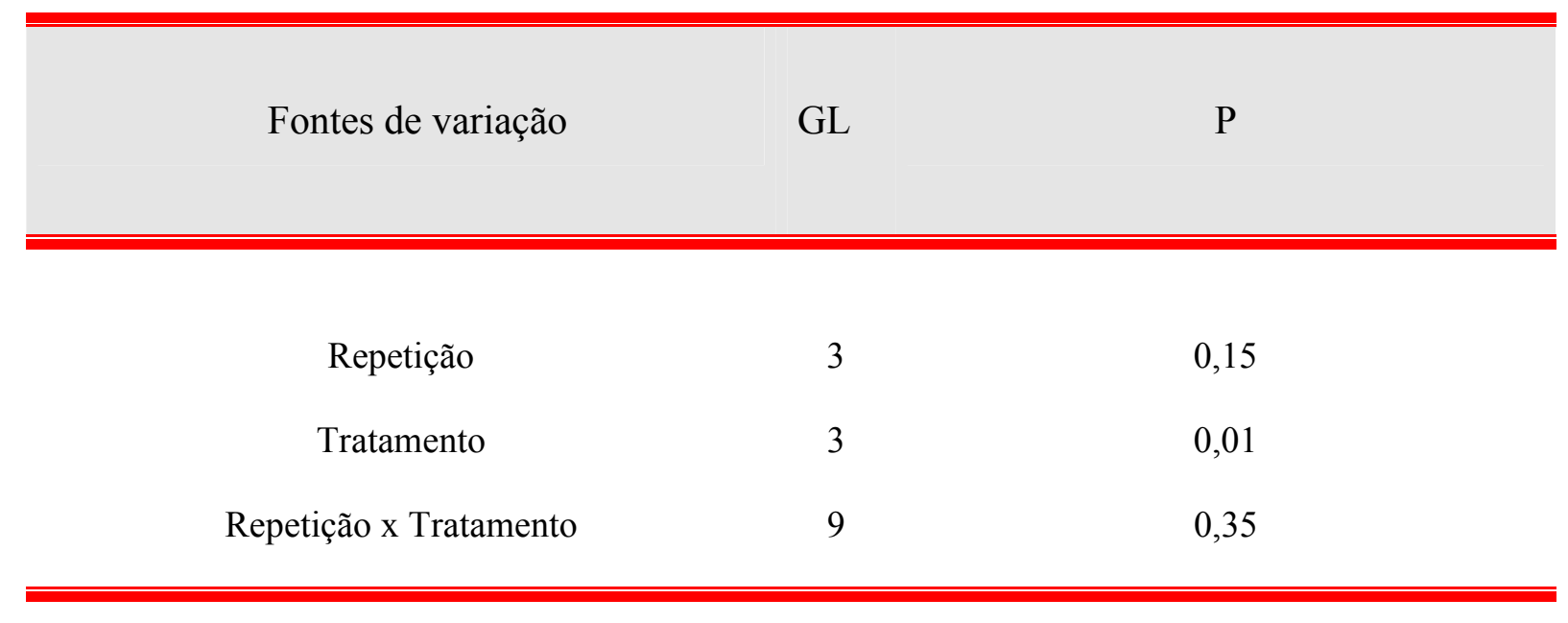

$r^{2}=0,53$ 


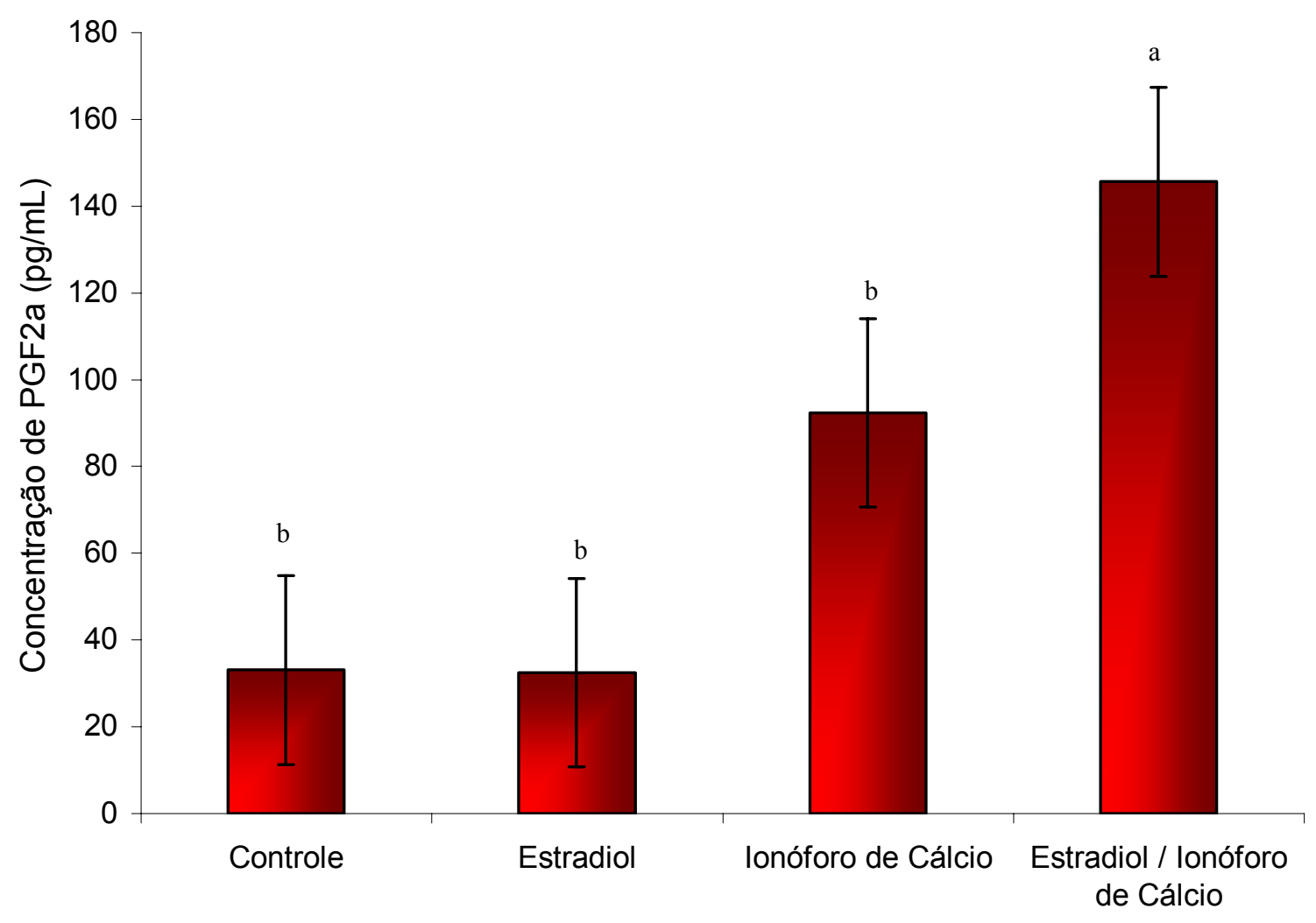

Gráfico 5 - Produção média (LSmeans \pm EPM) de PGF2 $\alpha$ (pg/mL/mg de tecido) por células BEND tratadas com 0 ou $10^{-13} \mathrm{M}$ de $\mathrm{E}_{2}$ e/ou 0 ou $10^{-6} \mathrm{M}$ de CI por 12 horas Pirassununga - Jan. 2004 a Abr. 2004

${ }^{* a, b}$ Barras designadas por letras diferentes diferem significativamente $(\mathrm{P} \leq 0,01)$ 
Vários trabalhos in vitro verificaram que o $\mathrm{E}_{2}$ administrado isoladamente em explantes endometriais não foi capaz de estimular a síntese de PGF2 $\alpha$ em animais no final da fase de diestro (RAW; SILVIA; CURRY, 1995; SKARZINSKY; BOGACKI; KOTWICA，1999; CASTRO E PAULA, 2003; DA CUNHA, 2004). Até o momento, não há estudos que tenham avaliado a capacidade do $E_{2}$ estimular a síntese de PGF2 $\alpha$ em células BEND. No presente experimento, células BEND tratadas exclusivamente com $E_{2}$ não tiveram a síntese de PGF2 $\alpha$ estimulada. Contudo, vários trabalhos in vivo demonstraram que o $\mathrm{E}_{2}$ é capaz de estimular a produção de PGFM (principal metabólito da PGF2 $\alpha$ ) em fêmeas no bovinas no $13^{\circ}$ (THATCHER et al., 1986), $15^{\circ}$ a $18^{\circ}$ (BERTHOLAZZI et al., 2003), $17^{\circ}$ (CASTRO E PAULA et al., 2003; JORGE et al., 2003) e $18^{\circ}$ dias do ciclo estral (RICO et al., 1981; KNICKERBOCKER et al., 1982). Assim, sugere-se que a síntese de PGF2 $\alpha$ estimulada pelo $\mathrm{E}_{2}$, estaria na dependência de outros fatores endógenos presentes no organismo animal, condição que não seria reproduzida em um sistema de cultivo de células, uma vez que os demais fatores endógenos estariam ausentes. Embora seja evidente a participação do $E_{2}$ na síntese de PGF2 $\alpha$ endometrial, permanecem desconhecidos os mecanismos pelos quais o $\mathrm{E}_{2}$ exerce este efeito.

Considerando os resultados obtidos no experimento 1 da presente tese, onde o aumento das concentrações de PGFM ocorreu 3 a 5,5 horas após a injeção de $\mathrm{E}_{2}$, tendo sido requerido um intervalo de tempo para que o $\mathrm{E}_{2}$ pudesse mediar a síntese de PGF2 $\alpha$. Tal observação sugere que tal estímulo envolveria uma ação genômica do $\mathrm{E}_{2}$, possivelmente estimulando a síntese de proteínas envolvidas na cascata geradora de PGF2 $\alpha$. Dados verificados por Da Cunha (2004) sugerem que a produção de PGF2 $\alpha$ in vitro não parece ser resultado de uma simples ativação de enzimas, que estariam disponíveis para transformar o AA em PGF2 $\alpha$, mas seria dependente de eventos complexos como transcrição, tradução e expressão de proteínas celulares, assim, eventos que requerem algumas horas para serem 
concluídos e determinarem uma resposta celular. Em complemento, vários trabalhos demostraram que a síntese de PGF2 $\alpha$ in vitro foi inibida pela ação da ciclohexamida (FAGAN; GOLBERG, 1986; LAFRANCE; GOFF, 1990; SLAMA; VAILLANCOURT; GOFF, 1994). O mecanismo de ação da ciclohexamida envolve a inibição da translocação do RNAm no ribossomo, impedindo a etapa de tradução na síntese de proteínas (ALBERTS et al., 1997) e parece não envolver a inativação de proteínas já existentes. Os receptores de estrógenos (ER) são divididos em dois subtipos: ER $\alpha$ e ER $\beta$, ambos estão presentes no endométrio bovino (ROSENFELD et al., 1998). Normalmente a ativação de RE $\alpha$ induz a respostas celulares imediatas que independem da transcrição gênica. A ação do $E_{2}$ na célula por ação genômica é promovida pelo complexo $\mathrm{E}_{2}$-receptor que ativa fatores transcripcionais ligados ao DNA representando a síntese de novas proteínas (ACCONCIA; MARINO, 2003). Possivelmente, o $\mathrm{E}_{2}$ estimule a síntese de PGF2 $\alpha$ pela prévia estimulação da transcrição e tradução de proteínas que poderiam representar enzimas, receptores o/ou outros fatores envolvidos na produção de PGF2 $\alpha$.

Embora no presente experimento não tenha havido diferença entre a produção de PGF2 $\alpha$ em células BEND tratadas com CI e o grupo controle, apenas uma tendência $(\mathrm{P} \leq 0,08)$, uma diferença numérica foi notável, representando um incremento de $179 \%$ em relação ao grupo controle. No experimento 3 da presente tese, células tratadas com $10^{-6} \mathrm{M}$ de CI tiveram a síntese de PGF2 $\alpha$ estimulada comparadas ao grupo controle. Vários trabalhos ilustram a importante participação do cálcio na síntese de PGF2 $\alpha$. Smith (1989) ilustra que o prévio tratamento do endométrio com bloqueadores dos canais de cálcio e antagonistas de proteínas ligadoras de cálcio, como a calmodulina, bloquearam a síntese de PGF2 $\alpha$. Também foi suficientemente reportado que a síntese de PGF2 $\alpha$ em células endometriais envolve a ativação das enzimas PKC e PLA 2 , ambas dependentes de cálcio para a ativação (BURNS et al., 1997). No presente estudo a adição do CI ao cultivo de células, resultou em um aumento 
das concentrações intracelulares de cálcio, aumentando a disponibilidade de cálcio para o desencadeamento de mecanismos intracelulares dependentes do mesmo, dentre eles, possivelmente a ativação das enzimas $\mathrm{PKC}$ e $\mathrm{PLA}_{2}$, envolvidas na síntese de PGF2 $\alpha$. Certamente a capacidade de amplitude do estímulo promovido pelo CI na síntese de PGF2 $\alpha$ seria dependente das concentrações intracelulares de PKC e $\mathrm{PLA}_{2}$ presentes nas células endometriais.

No presente estudo, quando o $\mathrm{CI}$ foi associado ao $\mathrm{E}_{2}$ a estimulação na síntese de PGF2 $\alpha$ foi maior do que em células tratadas exclusivamente com CI, sugerindo que um aumento na amplitude de resposta na síntese de PGF2 $\alpha$ promovida pelo cálcio estaria na dependência do $E_{2}$. No presente experimento apesar do $E_{2}$ não estimular a produção de PGF2 $\alpha$ quando utilizado exclusivamente, o $E_{2}$ foi capaz de amplificar o estímulo do CI na produção deste eicosanóide, efeito que foi observado tanto em explantes endometriais de fêmeas no $17^{\circ}$ dia do ciclo no experimento 2 da presente tese, como em células BEND. É interessante ressaltar que no experimento 2 da presente tese, realizado com explantes endometriais, apesar de todos os animais estarem no mesmo dia do ciclo estral observou-se uma variabilidade de resposta entre os animais e até mesmo entre os explantes. Contudo, no experimento 4 da presente tese, não houve variabilidade significativa entre as repetições experimentais, o que representa a principal vantagem de se trabalhar como o modelo experimental in vitro de células BEND, pois a baixa variabilidade entre as unidades de cultivo possibilita a análise do efeito isolado das variáveis estudadas. É importante salientar que apesar da variabilidade entre animais e explantes, os resultados obtidos no experimento 2 da presente tese foram bastante similares aos obtidos no experimento 4 .

Uma das possibilidades para a ação do $\mathrm{E}_{2}$ seria a de estimular a síntese de proteínas em células endometriais importantes na síntese de PGF2 $\alpha$, que seriam ativadas pelo cálcio, gerando desta forma uma resposta maximizada. Classicamente, o $\mathrm{E}_{2}$ exerce suas funções se 
unindo a seus receptores, que funcionam como fatores de transcrição (MOWA; IWANAGA, 2000a,b) portanto estimulam a transcrição gênica e a síntese de novas proteínas. Mas, para verificar a ação do $E_{2}$ na síntese de proteínas específicas, como as enzimas específicas envolvidas na síntese de PGF2 $\alpha$, seriam necessária a realização de novos experimentos utilizando técnicas de quantificação e qualificação de RNAm (Northern Blots e PCR quantitativo) e de proteínas (Western Blots). Especula-se que o $\mathrm{E}_{2}$ possa estimular diretamente a síntese de proteínas envolvidas na síntese de PGF2 $\alpha$, dentre elas, possivelmente a PKC e PLA 2 , que possuem domínios de ativação dependentes de cálcio.

Perret, Dockery e Harvey (2001) observaram que o 17ß-estradiol foi capaz de estimular a entrada de cálcio em células endometriais humanas da linhagem RL95-2, sendo sua ação nos canais que operam na entrada de cálcio e tal efeito foi dependente de PKC. Nesse estudo, concentrações fisiológicas de $17 \beta$-estradiol (1, 10, 100 e 1000nM) resultaram em um influxo transitório de cálcio intracelular 1 a 10 minutos após a adição, sendo que o influxo de maior concentração de cálcio foi obtido com a dose de $10 \mathrm{nM}$ de $17 \beta$-estradiol. Os mesmos autores reportam que o $17 \beta$-estradiol desencadearia um efeito imediato em células epiteliais do endométrio (linhagem RL95-2). O efeito máximo do $E_{2}$ no influxo de cálcio foi observado quando os estoques intracelulares de cálcio estavam em depleção. Tal efeito foi totalmente inibido em meio livre de cálcio, demonstrando que o aumento de cálcio no citosol foi proveniente do meio extracelular. A capacidade do $E_{2}$ em estimular a entrada de cálcio foi completamente abolida quando um inibidor de PKC foi adicionado ao meio. Os mesmos autores concluem que o $17 \beta$-estradiol e a PKC atuam nos canais de membrana que regulam a entrada de cálcio no citosol. No presente experimento o $E_{2}$ não estimulou a síntese de PGF2 $\alpha$ quando utilizado exclusivamente, assim, mesmo o $\mathrm{E}_{2}$ promova um aumento das concentrações intracelulares de cálcio, este não foi capaz de incrementar a síntese de PGF2 $\alpha$. Entretanto, seria possível que tal aumento de cálcio intracelular promovido pelo $\mathrm{E}_{2}$ quando associado ao 
CI pudesse contribuir para uma resposta máxima na síntese de PGF2 $\alpha$. Uma outra possibilidade, seria um ação genômica do $E_{2}$ que estimularia a síntese de proteínas formadoras dos canais de cálcio, favorecendo o influxo de cálcio do meio extracelular para o citosol, possibilitando a amplificação dos efeitos do CI. Considerando a participação da PKC no favorecimento da entrada de cálcio na célula, uma vez que o $\mathrm{E}_{2}$ estimulasse a síntese de PKC em células endometriais, o aumento das concentrações de cálcio no citosol também estaria sendo incrementada.

$\mathrm{Hu}$ et al. (2001) trataram células endometriais de suínos com inibidores para as diferentes isoformas de PKC, sendo eles: Gö6976 (inibidor de PKC $\alpha$, PKC $\beta 1$ e PKC $\mu$ ), Gö6983 (inibidor de PKC $\alpha, \mathrm{PKC} \beta, \mathrm{PKC} \gamma, \mathrm{PKC} \delta, \mathrm{PKC} \varepsilon$ e $\mathrm{PKC} \mu$ ) e Ro-31-8220 (inibidor de $\mathrm{PKC} \alpha, \mathrm{PKC} \beta 1, \mathrm{PKC} \beta 2, \mathrm{PKC} \gamma$ e PKC $\varepsilon$ ) e verificaram que a capacidade da OT em estimular a produção de PGF2 $\alpha$ em células endometrias foi abolida pelo três inibidores de PKC, demonstrando que a OT também atua promovendo a mobilização de DAG e cálcio pelo $\mathrm{IP}_{3}$ em células endometriais suínas, pré-requisitos para a ativação da PKC. Burns, Hayes e Silvia (1998) relataram no endométrio bovino que a ação da OT na síntese de PGF2 $\alpha$ seria dependente de cálcio, uma vez que sua ação estimulatória foi exacerbada na presença de drogas que favoreceram o acúmulo de cálcio no citoplasma e abolida na presença de tratamentos que previnem tal condição. No experimento 2 da presente tese, em explantes tratados com OT e $E_{2}$ a síntese de PGF2 $\alpha$ foi maior do que em explantes tratados somente com $E_{2}$. No presente experimento dessa tese, a ação do OT não foi associada a do $E_{2}$, pois a OT estava ausente no meio de cultivo e os receptores para a mesma são inexistentes em células BEND. Entretanto, uma outra possibilidade seria que a ação do $\mathrm{E}_{2}$ no controle dos canais dependentes de cálcio também favorecesse a ação da OT.

Relata-se que a ativação a ativação máxima da $\mathrm{PLA}_{2}$ ocorre com a fosforilação da serina 505 pela MAPK (LIN et al., 1993). As três maiores classes de MAPK são: quinases 
reguladas por sinais extracelulares (ERK1/2), c-Jun N-terminal/ proteína quinase ativada pelo stress (JNK/SAPK) e p38 MAPK (ROBINSON; COBB, 1997; LEWIS; SHAPIRO; AHN, 1998), sendo capazes de fosforilar PLA 2 . Razandi et al. (1999) relata que a ativação dos ER $\alpha$ ou ER $\beta$ estimulou de maneira significativa a atividade ERK. Os mesmos autores observaram que a ativação dos ER $\beta$ estimulou a atividade de JNK. Burns et al. (2001) verificaram embora as três maiores classes de MAPK estejam presentes no endométrio ovino, após o tratamento com OT a JNK-SAPK e p38 MAPK não foram encontradas na forma fosforilada, estando na forma fosforilada apenas ERK1/2, e que esta atuaria diretamente ou indiretamente na fosforilação da $\mathrm{PLA}_{2}$, resultando em um aumento na disponibilidade de AA para a síntese de PGF2 $\alpha$ ou ainda ERK1/2 estimularia a síntese de PGHS-2 que aumentaria a síntese de PGF2 $\alpha$. Os mesmos autores relatam que o aumento de cálcio intracelular seria requerido para a ativação da calmodulina e subsequente ativação de ERK1/2. Uma outra via que poderia ser responsável pela ativação de $\mathrm{PLA}_{2}$ seria pela ativação de Ras e Raf-1 que uma vez fosforilados ativariam MAPK que ativariam ERK1/2 que aumentariam a atividade de PLA 2 disponibilizando maior quantidade de AA para a síntese de PGF2 $\alpha$, porém o $\mathrm{E}_{2}$ sozinho não estimulou PGF2 $\alpha$. Estudos de Thatcher et al. (2001) identificaram em células endometriais bovinas BEND a importância da via Raf-1/MAPK/ERK1/2 quando a PKC foi ativada quando células foram tratadas com PDBu sugerindo que ERK1/2 seria o responsável pela fosforilação dos resíduos serina e treonina da $\mathrm{PLA}_{2}$, evento requerido para a obtenção de sua atividade máxima responsável pela maior disponibilização de AA e síntese de PGF2 $\alpha$. Coletivamente, tais evidências ilustram o fato de que as proteínas Gs, PLC, PKC, PLA 2 COX-2 e PGHS estão inseridas em um contexto molecular muito maior, onde a síntese de várias outras proteínas, traçam diferentes vias de ativação principalmente para $\mathrm{PKC}$ e $\mathrm{PLA}_{2}$. O E $\mathrm{E}_{2}$ poderia estar envolvido diretamente na síntese de $\mathrm{PKC}$ e $\mathrm{PLA}_{2}$ ou indiretamente mediando a síntese 
de ERK1/2, JNK/SAPK e p38 MAPK que associadas ao CI ativariam PKC e PLA 2 estimulando a síntese de PGF2 $\alpha$ no endométrio bovino.

Burlando et al. (2002) realizou um estudo com células sanguíneas de mexilhão, e relacionou como uma das ações do $\mathrm{E}_{2}$ a desestabilização da membrana lisossomal, facilitando a fusão dos lisossomos com os endossomos, evento celular que proporcionaria a degradação de uma maior quantidade de macromoléculas. Os mesmos autores observaram que quando tais células foram expostas ao $17 \beta$-estradiol houve um aumento na concentração de cálcio intracelular. Quando as células sanguíneas foram tratadas com $\mathrm{E}_{2}$ e CI ocorreu um aumento na quantidade de lisossomos em relação ao volume celular total, sendo tal efeito dependente $\mathrm{PLA}_{2}$ cálcio dependente. No mesmo estudo o $\mathrm{E}_{2}$ promoveu um aumento da translocação do $\mathrm{PLA}_{2}$ do citosol para a membrana facilitando a ativação da mesma.

No presente experimento o $\mathrm{E}_{2}$ potencializou os efeitos proporcionados pelo cálcio na síntese de PGF2 $\alpha$ em células endometriais bovinas, entretanto, os mecanismos pelos quais o $\mathrm{E}_{2}$ amplificou tal estímulo devem ser estudados. Existem muitas possibilidades para tal ação, entretanto, sugere-se que tal ação ocorra pela capacidade do $E_{2}$ estimular a síntese de proteínas e de maneira especialmente importante a PKC e PLA 2 que são estimuladas pelo cálcio na síntese de PGF2 $\alpha$ endometrial.

\subsection{CONCLUSÕES}

Células endometriais BEND tiveram a síntese de PGF2 $\alpha$ estimulada quando tratadas com o CI e $\mathrm{E}_{2}$ durante 12 horas, tendo o $\mathrm{E}_{2}$ amplificado a ação do CI. 
8. DISCUSSÃO GERAL

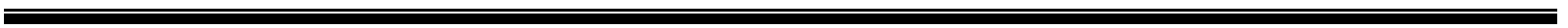




\section{DISCUSSÃO GERAL}

Embora tenha sido suficientemente reportada a importância do $E_{2}$ na luteólise de fêmeas bovinas (BRUNNER; DONALDSON; HANSEL, 1969; KARSH et al., 1970; HANSEL; CONCANNON; LUKASZEWSKA, 1973; GENGENBACH; HIXON; HANSEL, 1977; VILLA-GODOY et al., 1981; KNICKERBOCKER et al., 1986; THATCHER et al., 1986; HUGHES et al., 1987; SALFEN et al., 1999) os mecanismos pelos quais o $\mathrm{E}_{2}$ desempenha tal função permanecem desconhecidos.

Considerando que durante um período crítico do ciclo estral, compreendido entre o $15^{\circ}$ e o $19^{\circ}$ dia do ciclo estral, a síntese de PGF2 $\alpha$ precisa ser inibida para o estabelecimento da prenhez (THATCHER et al., 1986), julgou-se relevante o entendimento dos mecanismos pelos quais o $\mathrm{E}_{2}$ atua na síntese de PGF2 $\alpha$. O esclarecimento de tais mecanismos fundamentaram a presente tese. A aquisição de tal conhecimento, aumentaria as possibilidades de sucesso no desenvolvimento de estratégias anti-luteolíticas que objetivem minimizar a perda embrionária em programas de acasalamento e transferência de embriões durante o período compreendido entre o 15 e o $19^{\circ}$ dias do ciclo estral.

No experimento 1, evidenciou-se a capacidade do $\mathrm{E}_{2}$ em estimular o aumento das concentrações séricas de PGFM de maneira crescente ao longo do ciclo estral a partir do $15^{\circ}$ dia. A síntese de PGF2 $\alpha$ estimulada pelo $\mathrm{E}_{2}$ desencadeou-se de maneira mais rápida na medida que aumentaram os dias do ciclo. Possivelmente, uma das explicações para tal efeito possa se fundamentar nas observações de Boos et al. (1996) que observaram concentrações variáveis dos RE no endométrio ao longo do ciclo estral. Robinson et al. (2001) relataram que a menor expressão de RNAm para os RE foi verificada entre o 12 e $15^{\circ}$ dias do ciclo estral. Sugere-se a partir de tais evidências que antes do $16^{\circ}$ dia uma menor concentração de RE no endométrio representaria um fator limitante para que o mesmo estimulasse de maneira 
consistente a síntese de PGF2 $\alpha$. Outra possibilidade é que a ação do $E_{2}$ na síntese de PGF2 $\alpha$ possa ser mediada por outros hormônios, como a $\mathrm{P}_{4}$, OT e o $\mathrm{LH}$, que estariam presentes em concentrações diferenciadas ao longo do ciclo estral. No experimento 1 da presente tese, utilizou-se um modelo experimental in vivo, assim, embora tenha sido abordada a ação estimulatória do $\mathrm{E}_{2}$ na síntese de PGF2 $\alpha$, todos os demais fatores endógenos que compõem o mecanismo desencadeador da luteólise na síntese de PGF2 $\alpha$ estavam presentes durante a atuação do $E_{2}$. Constatou-se que fêmeas bovinas no $17^{\circ}$ dia do ciclo estral estabelecem um adequado modelo biológico in vivo e in vitro para o estudo dos mecanismos que envolvem a ação do $\mathrm{E}_{2}$ na síntese de PGF2 $\alpha$.

A presente tese evidência a capacidade do $\mathrm{E}_{2}$ estimular a síntese de PGF2 $\alpha$ in vivo (experimento 1) mas não in vitro quando utilizado exclusivamente (experimentos 2 e 4). No experimento 1, o perfil de resposta evidenciada após a injeção de $E_{2}$, tornou notável o fato de que a ação do $E_{2}$ no endométrio não foi imediata. Foi requerido um período de 3 a 3,5h para que as concentrações de PGFM fossem aumentadas e atingissem o pico com 6 a $6,5 \mathrm{~h}$. Considerando o intervalo de tempo estabelecido entre a injeção de $E_{2}$ e o aumento nas concentrações séricas de PGFM, sugere-se que a ação do $E_{2}$ na síntese de PGF2 $\alpha$ seja mediada por uma ação genômica, ou seja, decorreu-se em função da capacidade do $E_{2}$ em estimular a síntese de proteínas envolvidas diretamente ou indiretamente na cascata geradora de PGF2 $\alpha$. No modelo celular descrito por Ho e Liao (2002) o $\mathrm{E}_{2}$ se ligaria ao ER $\alpha$ e tal complexo atuaria no núcleo promovendo a transcrição gênica e a síntese de proteínas. Os ER foram divididos em dois subtipos: ER $\alpha$ e ER $\beta$. Ambos os subtipos estão presentes no endométrio bovino (KUIPER et al., 1996; ROSENFELD et al., 1998). Os ER $\alpha$ e ER $\beta$ foram identificados na membrana celular e no núcleo (RAZANDI et al., 1999). Diversos genes possuem em suas regiões promotoras, elementos de resposta que se acoplam aos receptores de $\mathrm{E}_{2}$ ativados pelo ligante. $\mathrm{O}$ elemento de resposta típico contém 5'-GGTCAnnnTGACC-3' 
como a seqüência de nucleotídeos necessária para que haja a ativação da transcrição do gene em resposta ao estradiol (DRISCOL et al., 1998).

No experimento 2, determinou-se que explantes endometriais fossem incubados na presença dos diferentes estimuladores celulares (CI, melitina e OT) aproximadamente 6,5h após a injeção de $\mathrm{E}_{2}$, período que coincidiu com a estimulação máxima promovida pelo $\mathrm{E}_{2}$ nos experimentos in vivo. Verificou-se que explantes endometriais tratados in vitro com CI, melitina ou OT, tiveram a síntese de PGF2 $\alpha$ estimulada comparados aos explantes não tratados previamente o tratamento com $\mathrm{E}_{2}$. De fato, tais observações confirmam a capacidade de tais estimuladores celulares na síntese de PGF2 $\alpha$ conforme dados descritos na literatura (DANET-DESNOYERS et al., 1995; BURNS et al., 1997; BURNS; HAYES; SILVIA, 1998; SKARZYNSKI; BOGACKI; KOTWICA, 1999; MANN, 2001). No mesmo estudo verificouse que o $E_{2}$ não foi capaz de amplificar os efeitos da melitina e OT, entretanto, potencializou os efeitos do CI. Sugere-se a partir de tais resultados que a ação do $E_{2}$ na síntese de PGF2 $\alpha$ é dependente de cálcio.

No presente estudo a estimulação na síntese de PGF2 $\alpha$ pelo CI era esperada, pois o aumento nas concentrações citoplasmáticas de cálcio parece ser um componente essencial no mecanismo regulatório intracelular da síntese de PGF2 $\alpha$, uma vez que o cálcio atua como um cofator para as enzimas PKC e PLA 2 . Em outro estudo, observou-se que no tecido uterino de ratas as concentrações de $\mathrm{PLA}_{2}$ foram aumentada 12 a 24 horas após a injeção de $\mathrm{E}_{2}$, sendo que tal efeito que foi bloqueado pela ciclohexamida, substância inibidora da síntese de proteínas (DEY; HOVERSLAND; JOHNSON, 1982).

No experimento 3, foi evidenciada a capacidade estimulatória do CI na síntese de PGF2 $\alpha$ em células BEND, sendo tal estímulo dose dependente. Quando células são expostas ao CI A23187, o cálcio é transportado pelo CI do líquido extracelular para o citosol a favor de um gradiente eletroquímico. Assim, o CI é amplamente usado em biologia celular para 
aumentar a concentração de cálcio livre no citosol (ALBERTS et al., 1997). O cálcio é um conhecido cofator para as enzimas PKC e PLA 2 , ambas responsáveis pela síntese de PGF2 $\alpha$. Considerando tais observações, possivelmente o CI estimularia a síntese de PGF2 $\alpha$ por ativar enzimas responsáveis por tal síntese, dependentes de cálcio. O aumento de cálcio intracelular favoreceria a ativação da PKC e PLA 2 , ambas dependentes de cálcio.

Guzeloglu et al. (2004) analizaram os isotipos de PKC presentes em células BEND e identificaram por Western Blotting a presença dos isotipos $\alpha, \varepsilon, \imath$ e $\lambda$. Os mesmos autores relatam que os outros isotipos de PKC poderiam ter uma baixa expressão ou os anticorpos utilizados na técnica de Western Blotting produzidos em camundongos poderiam não ser capazes de reconhecer os mesmos isotipos no endométrio bovino. Considerando os isotipos identificados em células BEND, apenas $\mathrm{PKC} \alpha$ é dependente de cálcio para sua ativação. Assim, possivelmente o estímulo na produção de PGF2 $\alpha$ ocasionada pelo CI possa ser atribuída ao favorecimento da ativação de PKC $\alpha$.

No experimento 4, testou-se a capacidade do $\mathrm{E}_{2}$ em amplificar a capacidade do CI em estimular a síntese de PGF2 $\alpha$ em células BEND. Observou-se que o tratamento com $\mathrm{E}_{2}$ associado ao CI estimulou uma maior síntese de PGF2 $\alpha$ nas células BEND comparado aos outros tratamentos. Em células tratadas exclusivamente com CI houve apenas uma tendência da síntese de PGF2 $\alpha$ ser maior do que nas células controles e tratadas somente com $\mathrm{E}_{2}$. $\mathrm{O}$ tratamento com $\mathrm{E}_{2}$ exclusivamente não estimulou a síntese de PGF2 $\alpha$ comparado ao grupo controle. O CI foi responsável por um incremento de $179 \%$ na produção de PGF2 $\alpha$ comparado ao grupo controle, entretanto, quando foi associado ao $E_{2}$ o incremento foi de $340 \%$ comparado ao grupo controle e de $58 \%$ comparado ao grupo tratado exclusivamente com CI. Assim, notavelmente o $\mathrm{E}_{2}$ aumentou a sensibilidade das células endometriais à ação do cálcio. 
Vários trabalhos in vitro verificaram que o $\mathrm{E}_{2}$ administrado isoladamente em explantes endometriais não foi capaz de estimular a síntese de PGF2 $\alpha$ em animais no final da fase de diestro (RAW; SILVIA; CURRY, 1995; SKARZINSKY; BOGACKI; KOTWICA, 1999; CASTRO E PAULA, 2003; DA CUNHA, 2004). Até o momento, não há estudos que tenham avaliado a capacidade do $E_{2}$ estimular a síntese de PGF2 $\alpha$ em células BEND. No presente experimento, células BEND tratadas exclusivamente com $E_{2}$ não tiveram a síntese de PGF2 $\alpha$ estimulada.

Coletivamente os dados gerados na presente tese reforçam a hipótese de que o $\mathrm{E}_{2}$ atuaria na síntese de PGF2 $\alpha$ possivelmente por mecanismos genômicos, estimulando a síntese de proteínas envolvidas na cascata geradora de PGF2 $\alpha$. De fato, dados verificados por Da Cunha (2004) sugerem que a produção basal de PGF2 $\alpha$ in vitro não parece ser resultado de uma simples ativação de enzimas, que estariam disponíveis para transformar o AA em PGF2 $\alpha$, mas seria dependente de eventos complexos como transcrição, tradução e expressão de proteínas celulares. Em complemento, vários trabalhos demostraram que a produção de PGF2 $\alpha$ in vitro foi inibida pela ação da ciclohexamida (FAGAN; GOLBERG, 1986; LAFRANCE; GOFF, 1990; SLAMA; VAILLANCOURT; GOFF, 1994). O mecanismo de ação da ciclohexamida envolve a inibição da translocação do RNAm no ribossomo, impedindo a tradução da síntese de proteínas (ALBERTS et al., 1997) e parece não envolver a inativação de proteínas já existentes.

No presente estudo a adição do CI ao cultivo de células BEND possivelmente contribuiu para a ativação das enzimas PKC e PLA 2 , envolvidas na síntese de PGF2 $\alpha$. Certamente a capacidade de amplitude do estímulo promovido pelo CI na síntese de PGF2 $\alpha$ seria dependente das concentrações intracelulares de $\mathrm{PKC}$ e $\mathrm{PLA}_{2}$ presentes nas células endometriais. Mas, para verificar a ação do $E_{2}$ na síntese de proteínas específicas, como as enzimas específicas envolvidas na síntese de PGF2 $\alpha$, seriam necessária a realização de novos 
experimentos utilizando técnicas de quantificação e qualificação de RNAm (Northern Blots e PCR quantitativo) e de proteínas (Western Blots).

Especulam-se vários mecanismos pelos quais o $\mathrm{E}_{2}$ poderia atuar estimulando a síntese de PGF2 $\alpha$. Os dados gerados na presente tese ilustram a capacidade do $E_{2}$ em estimular a síntese de PGF2 $\alpha$ in vivo (experimento 1), entretanto, tal capacidade não foi verificada in vitro (experimento 4). Nos estudos in vitro o CI foi capaz de estimular a síntese de PGF2 $\alpha$ em explantes e células endometriais (experimentos 2, 3 e 4), entretanto, seu efeito foi potencializado pelo $E_{2}$. Sugere-se a partir desses dados, que possivelmente o $E_{2}$ atua estimulando a síntese das enzimas $\mathrm{PKC}$ e $\mathrm{PLA}_{2}$, que na presença do CI promoveria a síntese de PGF2 $\alpha$ (Figura 3; A). Outro mecanismo possível de ação do $E_{2}$ seria por ação não genômica promover um influxo de cálcio no citosol e por ação genômica estimular a síntese de proteínas que integrariam ou favoreceriam o funcionamento dos canais de cálcio possibilitando o aumento intracelular de cálcio. Entretanto, considerando que o $\mathrm{E}_{2}$ utilizado exclusivamente em explantes e células não estimulou a síntese de PGF2 $\alpha$, sugere-se que o aumento de cálcio intracelular promovido pelo $\mathrm{E}_{2}$ poderia, associado ao aumento intracelular de cálcio promovido pelo CI desencadear uma estimulação máxima da síntese de PGF2 $\alpha$ (Figura 3, B).

Os receptores tirosina quinases são representados pelos receptores do fator de crescimento epidermal (EGF) e receptores para fator de crescimento semelhante a insulina I (IGF-I). Os receptores para as proteínas quinases incluem os receptores para o fosfoinositídeo 3 quinase $(\mathrm{P} 13 \mathrm{~K})$, serina-treonina quinase, proteínas quinases ativadas por mitógenos e proteínas quinases A e C. Muitas dessas vias são ativadas pelos RE presentes na membrana celular. Segundo o modelo descrito por Ho e Liao (2002) o $E_{2}$ se ligaria ao RE $\alpha$ e poderia ativar a cascata da família das proteínas quinases ativadas por mitógenos, incluindo a ativação de ERK1/2, JNK, p38 e proteínas quinases que formariam um complexo com Src e Ras. 
Nesse modelo, pela ativação das quinases por fatores mitogênicos, de maneira não nuclear, o ER $\alpha$ poderia amplificar a função dos fatores de transcrição. O ER $\alpha$ induz a rápida fosforilação do receptor de IGF-1 e ativação de ERK1/2, sugere-se que ocorre uma interação física direta entre ER $\alpha$ e o receptor de IGF-1 (KAHLERT et al., 2000). A ação do ER $\alpha$ na fosforilação de IGF-1, ilustra uma possível modulação do ER $\alpha$ na atividade nuclear por IGFI, mecanismo que independe da ação genômica direta do $E_{2}$ no núcleo celular. Os $E R \beta$ também estão presentes na membrana celular e uma vez ativados também desencadeiam respostas celulares por mecanismos não genômicos (HO; LIAO, 2002). Razandi et al. (1999) observaram que o ER $\beta$ ligado ao $\mathrm{E}_{2}$ é capaz de ativar a atividade da c-Jun quinase (JNK). A cJun ativada por JNK atuaria na transcrição gênica. Considerando tais observações, o $E_{2}$ poderia exercer indiretamente um efeito genômico na célula, não atuando como o próprio elemento de resposta na transcrição gênica, mas favorecendo a atuação de outros elementos de resposta.

Outra possibilidade de atuação do $\mathrm{E}_{2}$ seria pela participação estimulando as vias ERK1/2, JNK/SAPK e p38 MAPK, pelo estímulo na síntese dessas proteínas ou na ativação de tais proteínas, que associadas a $\mathrm{CI}$ ativariam $\mathrm{PKC}$ e $\mathrm{PLA}_{2}$ estimulando a síntese de PGF2 $\alpha$ no endométrio bovino (Figura 3, C). Ainda seria possível a interação destes mecanismos. Mais estudos devem ser realizados para determinarem os efeitos do estradiol associado ao CI. Conclui-se que em fêmeas bovinas o $E_{2}$ potencializou os efeitos do CI na síntese de PGF2 $\alpha$ endometrial. Propõe-se que o $\mathrm{E}_{2}$ ativa a síntese de enzimas que, estimuladas pelo cálcio, atuam na síntese de PGF2 $\alpha$ endometrial. 


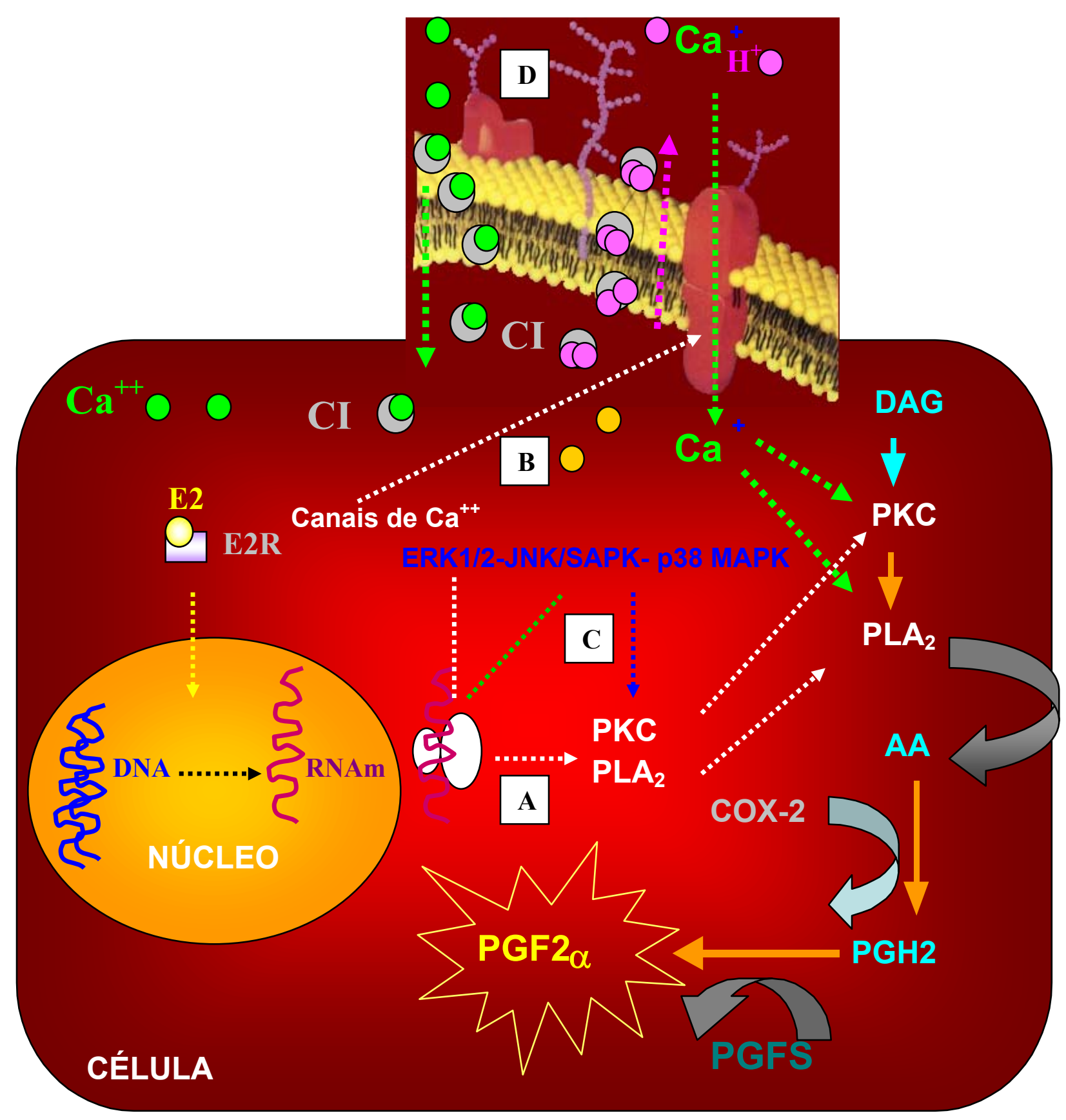

Figura 3 - Modelo hipotético ilustrando os possíveis mecanismos de atuação do $E_{2}: 0 E_{2}$ estimularia a síntese das enzimas PKC e $\mathrm{PLA}_{2}$ dependentes de cálcio e/ou (A); o $\mathrm{E}_{2}$ atuaria nos canais de cálcio aumentando a concentração intracelular de cálcio que associado ao CI promoveria a estimulação máxima da síntese de PGF2 $\alpha$ (B); o $\mathrm{E}_{2}$ participaria mediando a síntese e/ou a ativação de ERK1/2, JNK/SAPK e p38 MAPK que associadas ao CI ativariam PKC e PLA estimulando a síntese de PGF2 $\alpha$ no endométrio bovino (C). Mecanismo de ação do CI como transportador iônico, promovendo a entrada do íon cálcio $(\bullet)$ e a saída dos íons de hidrogênio (•) do compartimento celular (D). 
9. CONCLUSÕES 


\section{CONCLUSÕES}

- A capacidade secretória de PGF2 $\alpha$ estimulada pelo estradiol é crescente ao longo dos dias que antecedem a luteólise $\left(13^{\circ}\right.$ ao $19^{\circ}$ dia do ciclo $)$, evidenciando-se que o $17^{\circ}$ dia do ciclo estral é o melhor dia para a realização de estudos in vivo e in vitro dos mecanismos moleculares pelos quais o estradiol estimula a síntese de PGF2 $\alpha$;

- O ionóforo de cálcio, a melitina e a ocitocina estimularam a síntese de PGF2 $\alpha$ quando comparados ao grupo controle, independentemente de terem sido ou não expostos ao tratamento in vivo com $\mathrm{E}_{2}$. Entretanto, o estímulo promovido pelo ionóforo de cálcio na síntese de PGF2 $\alpha$ foi potencializado quando explantes foram previamente expostos ao $\mathrm{E}_{2}$;

$\checkmark \quad$ Células endometriais bovinas "BEND" tiveram a síntese de PGF2 $\alpha$ estimulada pelo ionóforo de cálcio quando adicionado ao meio de cultivo por $12 \mathrm{~h}$, sendo tal estímulo dose dependente;

$\checkmark \quad$ Células endometriais bovinas "BEND" tiveram a síntese de PGF2 $\alpha$ estimulada quando tratadas com o ionóforo de cálcio e E2 durante 12 horas, tendo o E2 amplificado a ação do ionóforo de cálcio. Conclui-se que o E2 ativa a síntese de enzimas estimuladas pelo cálcio na síntese de PGF2 $\alpha$ endometrial. 
REFERÊNCIAS BIBLIOGRÁFICAS 


\section{REFERÊNCIAS}

ACCONCIA, F.; MARINO, M. Synergism between genomic and non genomic estrogen action mechanism. IUBMB Life, v. 55, n. 3, p. 145-50, 2003.

ALBERTS, B.; BRAY, D.; LEWIS, J.; RAFF, M.; ROBERTS, K.; WATSON, J. D. Biologia Molecular da Célula. 3. ed. Porto Alegre: Artes Médicas, 1997. 1294 p.

ALILA, H. W.; HANSEL, W. Origin of different cell types in bovine corpus luteum as characterized by specific monoclonal antibodies. Biology of Reproduction, v. 31, p. 10151025, 1984.

ALVAREZ, P.; SPICER, L. J.; CHASE, JR., C. C.; PAYTON, M. E.; HAMILTON, T. D.; STEWART, R. E.; HAMMOND, A. C.; OLSON, T. A.; WETTMANN, R. P. Ovarian and endocrine characteristics during estrous cycle in Angus, Brahman and Senepol cows in a subtropical environment. Journal of Animal Science, v. 78, p. 1291-1302, 2000.

ANDERSON, L. E.; WU, Y. L.; TSAI, S. J. Prostaglandin F(2alpha) receptor in the corpus luteum, recent information on the gene, messenger ribonucleic acid, and protein. Biology of Reproduction, v. 64, n. 4, p. 1041-1047, 2001.

ARANDA, A.; PASCUAL, A. Nuclear hormone receptors and gene expression. Physiological Rewiews, v. 81, n. 3, p. 1269-1304, 2001.

ARMSTRONG, D. T.; HANSEL, W. Alteration of bovine estrous cycle with oxytocin. Journal of Dairy Science, v. 42, p. 533-542, 1959.

ARNOLD, D. R.; BINELLI, M.; VONK, J.; ALEXENKO, A. P.; DROST, M.; WILCOX, C. J.; THATCHER, W. W. Intracellular regulation of endometrial $\mathrm{PGF} 2 \alpha$ and $\mathrm{PGE}_{2}$ production in dairy cows during early pregnancy and following treatment with recombinant interferon- $\tau$. Domestic Animal Endocrinology, v. 18, p. 199-216, 2000.

ASSELIN, E.; GOFF, A. K.; BERGERON, H.; FORTIER, M. A. Influence of sex steroids on the production of prostaglandin $\mathrm{F} 2 \alpha$ and $\mathrm{E}_{2}$ and response to oxytocin in cultured epithelial and stromal cells of bovine endometrium. Biology of Reproduction, v. 54, p. 371-379, 1996.

AULETTA, J. F.; FLINT, A. P. F. Mechanisms controlling corpus luteum function in sheep, cows, non human primates and women, especially in relation to the time of luteolysis.

Endocrine Reviews, v. 9, p. 88-105, 1988. 
BADINGA, L.; GUZELOGLU, A.; THATCHER, W. W. Bovine Somatotropin attenuates phorbol-ester induced prostaglandin F2alpha production in bovine endometrial cells. Journal of Dairy Science, v. 85, p. 537-543, 2002.

BANU, S.K.; AROSH, J.A.; CHAPDELAINE, P.; FORTIER, M.A. Molecular cloning and spatio-temporal expression of the prostaglandin transporter: A basis for the action of prostaglandins in the bovine reproductive system. PNSA, v. 30, n. 20, p. 11747-11752, 2003.

BAO, B.; GARVERICK, H. A. Expression of steroidogenic enzyme and gonadotropin receptor genes in bovine follilcles during ovarian follicular waves: a review. Journal of Animal Science, v. 76, n. 7, p. 1903-1921, 1998.

BASHA, S. M. M.; BAZER, F. W.; ROBERTS, R. M. Effect of the conceptus on quantitative and qualitative aspects of uterine secretion in pigs. Journal of Reproduction and Fertility, v. 60, p. $41,1980$.

BASU, S.; KINDAHL, H. Development of a continuous blood collection technique and a detailed study of prostaglandin F2 $\alpha$ release during luteolysis and early pregnancy in heifers. Journal of Veterinary Medicine, v. 34, p. 487-500, 1987 b.

BATRA, S. Effect of estrogen and progesterone treatment on calcium uptape by the myometrium and smooth muscle of the lower urinary tract. European Journal

Pharmacology, v. 127, p. 37-42, 1986.

BEARD, A. P.; LAMMING, G. E. Oestradiol concentration and the development of uterine oxytocin receptor and oxytocin-induced PGF $2 \alpha$ release in ewes. Journal of Reproduction and Fertility, v. 100, p. 469-475, 1994.

BERGSTROM, S.; DANIELSSON, H.; KLENBERG, D.; SAMUELSON, S. The enzymatic conversion of essential fatty acids into prostaglandins. Journal of Biological Chemistry, v. 239, p. 4006-4009, 1964.

BERRIDGE, M. J. Inositol trisphosphate and calcium signalling. Nature, v. 361, n. 28, p. 315-325, 1993.

BERTHOIS, Y.; POURREAU-SCHNEIDER, N.; GANDILHON, P.; MITTRE, H.; TUBIANA, N.; MARTIN, P.M. Estradiol membrane binding sites on human breast cancer cell lines: use of a fluorescent estradiol conjugate to demonstrate plasma membrane binding system. Journal Steroid of Biochemical, v. 25, p. 963-972, 1986.

BERTHOLAZZI, A.; JORGE, P.; BERTAN, C. M.; CASTRO E PAULA, L. A.; DA CUNHA, P. M.; LOUREIRO, J. G. P.; TEIXEIRA, A. B.; BARROS, C. M.; BINELLI, M. Efeitos do benzoato de estradiol (eb) e cipionato de estradiol (ECP) na liberação de 
prostaglandina $\mathrm{F}_{2 \alpha}(\mathrm{pgf} 2 \alpha)$ em bovinos. In: CONGRESSO DE INTEGRAÇÃO EM BIOLOGIA DA REPRODUÇÃO, Ribeirão Preto. Anais do Congresso de Integração em Biologia da Reprodução, Ribeirão Preto, 2003, p.307.

BINELLI, M.; GUZELOGLU, A.; BADINGA, L.; ARNOLD, D. R.; SIROIS, J.; HANSEN, T. R.; THATCHER, W. W. Interferon-T modulates phorbol Ester-induced production of prostaglandin and expression of cyclooxygenase- 2 and phospholipase- 2 from bovine endometrial cells. Biology of Reproduction, v. 63, p. 417-424, 2000.

BOSS, A.; MEYER, W.; SCHWARZ, R.; GRUNERT, E. Immunohistochemical assessment of oestrogen receptor and rogesterone receptor distribution in biopsy samples of the bovine endometrium collected throughout the oestrus cycle. Animal Reproduction Science, v. 44, p. 11-21, 1996.

BROWN, M. S.; GOLDSTEIN, J. L. A receptor-mediated path-way for cholesterol homeostasis. Science, v. 232, p. 34-47, 1986.

BURLANDO, B.; MARCHI, B.; PANFOLI, I.; VIARENGO, A. Essential role $\mathrm{Ca}^{2+}$ dependent phospholipase $\mathrm{A}_{2}$ in estradiol-induced lysosome activation. Animal Journal Physiol Cell Physiol, v. 283, p. 1461-1468, 2002.

BURNS, P. D.; GRAF, G. A.; HAYES, S. H.; SILVIA, W. J. Cellular mechanisms by which oxytocin stimulates uterine $\mathrm{PGF}_{2 \alpha}$ alpha synthesis in bovine endometrium: roles of phospholipases C and A2. Domestic Animal Endocrinology, v. 14, n. 3, p. 181-191, 1997.

BURNS, P. D.; GRAF, G. A.; HAYES, S. H.; SILVIA, W. J. Effect of oxytocin on expression of cytosolic phospholipase $\mathrm{A}_{2} \mathrm{mRNA}$ and protein in ovine endometrial tissue in vivo. Domestical Animal Endocrinology, v. 19, p. 237-246, 2000.

BURNS, P. D.; HAYES, S. H.; SILVIA, W. J. Cellular mechanisms by which oxytocin mediates uterine prostaglandin F2 $\alpha$ synthesis in bovine endometrium: role of calcium. Domestic Animal Endocrinology, v. 15, n. 6, p. 477-487, 1998.

BURNS, P. D.; MENDES JR., J. O.; YEMM, R. S.; CLAY, C. M.; NELSON, S. E.; HAYES, S. H.; SILVIA, W. J. Cellular mechanisms by which oxytocin mediates ovine endometrial prostaglandin F2 alpha synthesis: role of G(i) proteins and mitogen-actived protein kinases. Biology of Reproduction, v. 65, n. 4, p. 1150-1155, 2001.

BRUNNER, M.A.; DONALDSON, L.E.; HANSEL, W. Exogenous hormones and luteal function in hysterectomized and intact heifers. Journal of Dairy Science, v. 52, p. 18491854, 1969. 
CANINO, C. J.; REED, J.; SHEMESH, M.; CHANG, S. M. T.; MARINO, V. K.; HIERS, E. A.; BINTA, H.; LUCE, B. R.; THATCHER, W. W.; FIELDS, M. J. Induction of prostaglandin synthesis via LH/hCG-mediated receptors in the bovine uterus. Biology of Reproduction. v. 60, p. 262, 1999. Supplement 1.

CARAMBULA, S. F.; MAITIKAINEM, T.; LYNCH, M. P.; FLAVEL, R. A.; DIAS GONÇALVES, P. B.; TYLLI, J. L.; RUEDA, B. R. Caspase-3 is a pivotal mediator of apoptosis during regression of ovarian corpus luteum. Endocrinology, v. 143, n. 4, p. 495$501,2002$.

CASTRO E PAULA, L. A. As funções do estradiol no processo da luteólise em bovinos: o papel da ocitocina na produção de PGF2a. 2003. 202 f. Dissertação (mestrado) - Faculdade de Medicina Veterinária e Zootecnia, Universidade de São Paulo, São Paulo, 2003.

CASTRO E PAULA, L. A.; LOUREIRO, J. G. P.; MEMBRIVE, C. M. B.; DA CUNHA, P. M.; BERTHOLAZZI, A.; JORGE, P.; MADUREIRA, E. H.; BINELLI, M. Effects of Estradiol-17 $\beta$ on prostaglandin F2alpha (PGF) secretion in cattle: in vitro in vivo responses. Biology of Reproduction, v. 66, p. 324, 2002. Supplemente 1.

CASTRO E PAULA, L. A.; LOREIRO, J. G. P.; MEMBRIVE, C. M. B.; DA CUNHA, P. M.; MADUREIRA, E. H.; BINELLI, M. Caracterização de um sistema de Perifusão para explantes de endométrio bovino: efeito do método de processamento do tecido na secreção de PGF $_{2 \alpha}$ estimulada por um forbol ester. In: ANAIS DO CONGRESSO DE INTEGRAÇÃO EM BIOLOGIA DA REPRODUÇÃO, 2001, Ribeirão Preto. Anais do Congresso de Integração em Biologia da Reprodução, 2001. p. 71.

CHAN, H. C.; LIU, C. Q.; FONG, S. K.; LAW, S. H.; WU, L. J.; SO, E.; CHUG, Y. W.; KO, W. H.; WONG, P. Y. Regulation of $\mathrm{Cl}^{-}$secretion by extracellular ATP in cultured mouse endometrial epithelium. Journal of Membrane Biology, v. 156, p. 45-52, 1997.

CHANNON, J. Y.; LELSLIE, C. C. A calcium-dependent mechanism for associating a soluble arachidonoyl-hydrolyzing phospholipase A2 with membrane in the macrophage cell line RAW 264.7. Journal Biological Chemistry, v. 265, p. 5409-5413, 1990.

CHEN, D. B.; WESTFALL, S. D.; FONG, H. W.; ROBERSON, M. S.; DAVIS, J. S. Prostaglandin F2 $\alpha$ stimulates the Raf/MEK1/Mitogen-activated protein kinase signaling cascade in bovine luteal cells. Endocrinology, v. 139, p. 3876-3885, 1998.

CHEN, G. T. C.; GETSIOS, S.; MACCALMAN, M. 17-beta-estradiol potentiates the stimulatory effects of progesterone on cadherin-11 expression in cultured human endometrial cells. Endocrinology, v. 139, p. 3512-3519, 1998. 
CHUN, J. S.; HA, M. J.; JACOBSON, B. S. Differential translocation of protein kise C $\varepsilon$ during HeLa cell adhesion to a gelatin substratum. Journal Biological Chemistry, v. 271, p. 13008-13012, 1996.

CLARK, J. D.; LIN, L. L.; KRIZ, R. W.; RAMESH, C. S.; SULTZMAN, L. A.; LIN, A. Y.; MILONA, N.; KNOPF, J. L. A novel arachidonic acid-seletive cytosolic PLA2 contains $\mathrm{Ca}^{2+}-$ dependent translocation domain with homology to PKC and GAP. Cell, v. 65, p. 1043-1051, 1991.

CLARK, J. D.; SCHIEVELLA, A. R.; NALEFSKI, E. A.; LIN, L. L. Cytosolc phospholipase A2. Journal Lipid Mediator Cell Signal, v. 12, p. 83-117, 1995.

COHN, S. M.; SCHOLOEMANN, S.; TESSNER, T.; SEIBRIT, K.; STENSON, W. F. Crypt stem cell survival in the mouse intestinal epithelium is regulated by prostaglandins synthesized through cyclooxygenase-1. Journal of Clinic Investigation, v. 99. p. 13671379, 1997.

DA CUNHA, P. M. O estímulo do estradiol na produção de PGF2 $\alpha$ endometrial é dependente da síntese de proteínas? 2004. 146 f. Dissertação (mestrado) - Faculdade de Medicina Veterinária e Zootecnia, Universidade de São Paulo, São Paulo, 2004.

DANET-DESNOYERS, G.; MEYER, M. D.; GROSS, T. S.; JOHNSON, J. W.; THATCHER, W. W. Regulation of endometrial prostaglandin syntheis during early pregnancy in cattle: effects of phospholipase and calcium in vitro. Prostaglandins, v. 50, p. 313-330, 1995.

DANET-DESNOYERS, G.; WETZELS, C.; THATCHER, W. W. Natural and Recombinant interferon- $\tau$ regulate basal and oxytocin- induced secretion of prostagalndins $F 2 \alpha$ and $E_{2}$ by epithelial cells and estromal cells in the endometrium. Reproduction and Fertility Development, v. 6, p. 193-202, 1994.

DAVIS, S. R.; COLLIER, R. J.; MCNAMARA, J. P. Effects of thyroxine and growth hormone treatment of dairy cows on mammary uptake of glucose, oxygen and other milk fat precursors. Journal of Animal Science, v. 66, p. 80-89, 1988.

DIAZ, F. J.; ANDERSON, L. E.; WU, Y. L.; RABOT, A.; TSAI, S. J.; WILTBANK, M. C. Regulation of progesterone and Prostaglandin $\mathrm{F}_{2 \alpha}$ production in the CL. Molecular and Cellular Endocrinology, v. 191, p. 65-68, 2002.

DIAZ, T.; SCHIMITT, E. J-P.; DE LA SOTA, R. L.; THATCHER, M-J.; THATCHER, W. W. Human chorionic gonadotropin-induced alterations in ovarian follicular dynamics during the estrous cycle of heifers. Journal of Animal Science, v. 76, p. 1929-1936, 1998. 
DIELEMAN, S. J.; BEVERS, M. M. Effects of monoclonal antibody against PMSG administered shortly after the preovulatory LH surge on time and number of ovulations in PMSG/PG-treated cows. Journal Reproduction and Fertility, v. 81, n. 2, p. 533-542, 1987.

DISKIN, M. G.; SREENAN, J. M. Fertilization and embryonic mortality rates in beef heifers after artificial insemination. Journal of Fertility and Reproduction, v. 59, p. 463-468, 1980.

DOCKERY, P.; KHALID, J.; SARANI, A. S.; BULUT, H. E.; WARREN, M. A.; LI, T. C.; COOKE, I. D. Changes in basement membrane thickness in the human endometrium during the luteal phase of the mestrual cycle. Human Reproduction Update, v. 4, p. 486-495, 1998.

DRISCOLL, M.D.; SATHYA, G.; MUYAN, M.; KLING, C.M.; HILF, C.M.; HILF, R.; BAMBARA, R..A. Sequence requirements for estrogen receptors binding to estrogen response elements. Journal Biological of Chemistry, v. 273, p. 28121-28140, 1998.

ENMARK, E.; PELTRO-HUIKKO, M.; GRANDIEN, K.; LAGERCRANTZ, S.; LAGERCRANTZ, J.; FRIED, G.; NORDENSKJÖLD, M.; GUSTAFSSON, J. Human estrogen receptor $\beta$-gene structure, chromosomal localization, and expression pattern. Journal of Endocrinology and Metabolism, v. 82, n. 12, p. 4258-4265, 1997.

FAGAN, J. M.; GOLDBERG, A. L. Inhibitors of protein and RNA synthesis cause a rapid block in prostaglandin production at the prostaglandin synthase step. Proceedings of the National Academy of Sciences of United States of America, v. 83, p. 2771-2775, 1986.

FIELDS, M. J.; FIELDS, P. A. Morphological characteristics of the bovine corpus luteum during estrous cycle and pregnancy. Theriogenology, v. 45, p. 1295-1325, 1996.

FINDLAY, J. K.; CLARKE, I. J.; SWANEY, J.; COLVIN, N.; DOUGHTON, B. Oestrogen receptors and protein synthesis in caruncular and intercaruncular endometrium of sheep before implantation. Journal of Reproduction and Fertility, v. 64, p. 329-339, 1982.

FITZ, A.; MAYAN, M. H.; SAWYER, H. R. Characterization of two steroidogenic cell types in the ovine corpus luteum. Biology of Reproduction, v. 27, p. 703-722, 1984.

FLINT, A.P.F.; LEAT, W.M.F.; SHELDRICK, E.L.; STEWART, H.J. Stimulation of phosphoinositid

FORTUNE, J. E.; QUIRK, S. M. Regulation of steroidogenesis in bovine preovulatory follicles. Journal of Animal Science, v. 66, p. 1-8, 1988. 
FRASER, H. M.; ABBOTT, M.; LAIRD, N. C. Effects of an LH-releasing hormone antagonist on the secretion of LH, FSH, prolactin and ovarian steroids at different stages of the luteal phase in the stumptailed macaque (Macaca arctoides). Journal of Endocrinology, v. 111, n. 1, p. 83-90, 1986.

FREDRICKSON, G.; KINDAHL, H.; EDQVIST, L. E. 11-Ketotetranor PGF metebolites, a suitable indicator for measuring prostaglandin release during the normal oestrus cycle and early pregnancy in the goat. Animal Reproduction Science, v. 7, p. 537-545, 1984.

FREIDMAN, S.; GUREVICH, M.; SHEMESH, M. Bovine cyclic endometrium contains high-affinity luteinizing hormone/ human chorionic gonadotropin binding sites. Biology of Reproduction, v. 52, p. 1020-1026, 1995.

GENGENBACH, D.R.; HIXON, J.E.; HANSEL, W. A luteolytic interaction between estradiol and prostaglandin F2 $\alpha$ in histerectomized ewes. Biology of Reproduction, v. 16, p. $571,1977$.

GIJON, M. A.; LESLIE, C. C. Regulation of arachidonic acid release and cytosolic phospholipase $A_{2}$ activation. Journal of Leukocites Biology, v. 65, p. 330-336, 1999.

GINTHER, O. J.; KNOPF, L.; KASTELIC, J. P. Temporal associations among ovarian events in cattle during oestrus cycles with two and three follicular waves. Theriogenology, $\mathrm{v}$. 87, n. 1, p. 223-230, 1989.

GIRSH, E.; MILVAE, R.; WANG, W. Effect of endothelin-1 on bovine luteal cell function, role in prostaglandin F2 $\alpha$-induced a steroidogenic action. Endocrinology, v. 137, p. 13061312, 1996.

GIRSH, E.; WANG, W.; MAMLUCK, R. Regulation of endothelin-1 expression in the bovine corpus luteum, elevation by prostaglandin F2 $\alpha$. Endocrinology, v. 137, p. 5191-5196, 1996.

GOODE, N. T.; NASSER-HAJIBAGHERI, M. A; PARKER, P. J. Protein kinase C (pkc)induced PKC down-regulation. Journal Biological Chemistry, v. 270, p. 2669-26 73, 1995.

GOSPODAROWICZ, D.; CHENG, J.; LUI, G. M. Corpus luteum angiogenic factor is related to fibroblast growth factor. Endocrinology, v. 117, n. 6, p. 2383-2391, 1985.

GRAF, G. A.; BURNS, P. D.; SILVIA, W. J. Expression of a cytosolic phospholipase A2 by ovine endometrium on days 11-14 of a simulated oestrous cycle. Journal of Reproduction and Fertility, v. 115, p. 357-363, 1999. 
GRAZUL-BILSKA, A. T.; REDMER, D. A.; KILLILEA, S. D. Production of mitogenic factor(s) by ovine corpora lutea throughout the estrous cycle. Endocrinology, v. 130, n. 6, p. 3625-3632, 1992.

GREENE, G. L.; PRESS, M. F. Structure and dynamics of the estrogen receptor. Journal of Steroid Biochemistry, v. 24, n. 1, p. 1-7, 1986.

GUZELOGLU, A.; BINELLI, M.; BADINGA, L.; HANSEN, T. R.; THATCHER, W. W. Inhibition of phorbol ester-induced PGF2 $\alpha$ secretion by IFN- $\tau$ is not through regulation of protein kinase C. Prostaglandins, 2004. No prelo.

GUZELUGLU, A.; MICHEL, F.; THATCHER, W. W. Differential effects of interferon- $\tau$ on the prostaglandin synthetic pathway in bovine edometrial cells treated with phorbol ester. Journal of Dairy Science, v . 87, p. 2032-2041, 2004.

HAFEZ, E. S. E. Anatomy of female reproduction. In, HAFEZ, E. S. E. (Ed) Reprodution in farm animals. 6. ed. Philadelphia: Lea \& Febiger, 1993. p. 20-55.

HAMM, H.E. The many faces of G protein signaling. Journal Biological Chemistry, v. 273, p. 669-672, 1998.

HANK, H.W. Infertility in dairy cattle. In: HANK, H. W. (Ed). Beltsville Symposia in agricultural research. 3. Animal Reproduction, Allanheld, Osmun and Co, Montclair, New Jersey, 1979, p. 19-29.

HANSEL, H.; CONCANNON, P. W.; LUKASZEWSKA, J. H. Corpora lutea of large domestic animals. Biology of Reproduction, v. 8, p. 222, 1973.

HANSEL, W.; ALILA, H. W.; DOWD, J. P. Control of steroidogenesis in small and large bovine luteal cells. Australian Journal Biological Science, v. 40, n. 3, p. 331-347, 1987.

HIXON J.; FLINT, A. P. F. Effects of luteolytic dose of oestradiol benzoate on uterine oxytocin receptor concentrations, phosphoinositide turnover and prostaglandin F2 $\alpha$ secretion in sheep. Journal of Reproduction and Fertility, v. 79, p. 475-487, 1987.

HIXON, J. E.; HANSEL, W. Evidence for preferential transfer of prostaglandin F2alpha to the ovarian artery following intrauterine administration in cattle. Biology of Reproduction, $v$. 11, n. 5, p. 543-552, 1974. 
HO, A. K.; KLEIN, D. C. Activation of alpha 1-adrenoreceptors, protein kinase C, or treatment with intracellular free $\mathrm{Ca}^{+2}$ elevating agents increases pineal phospholipase $\mathrm{A}_{2}$ activity. Journal Biological Chemistry, v. 262, p. 11764-11769, 1987.

HO, K. J.; LIAO, J. K. Non-nuclear actions of estrogen: new targets for prevention and treatment cardiovascular disease. Molecular Interventions, v. 2, n. 4, p. 219-228, 2002.

HOFMANN, J. The potential for isoenzyme-selective modulation of protein kinase C. The FASEB Journal, v. 11, p. 649-669, 1997.

HOLUB, B. J.; CELI, B. Evaluation of fatty acid selectivity of phosphatidylinositol-specific cytosolic phospholipase $\mathrm{C}$ from pig ad human platelets. Canadian Journal Biochemistry and Cell Biology, v. 62, p. 115-120, 1984.

HORN, S.; BATHGATE, R.; LIOUTAS, C.; BRAKEN, K.; IVELL, R. Bovine endometrial epithelial cells as a model system to study oxytocin receptor regulation. Human

Reproduction Update, v. 4, n. 5, p. 605-614, 1998.

HU, J.; BRAILEANU, G. T.; MIRANDO, M. A Oxytocin stimulates prostaglandin F2alpha secretion from porcine endometrial cells through activation of calcium-dependent protein kinase C. Prostaglandins \& Other Lipid Mediators, v. 65, n. 2-3, p. 85-101, 2001 b.

HU, J.; LUDWIG, T.E.; SALLI, U.; STORMSHAK, F.; MIRANDO, M.A.

Autocrine/Paracrine action of oxytocin in pig endometrium. Biology of Reproduction, v. 64, p. 1682-1688, 2001.

HUGHES, T. L.; VILLA-GODOY, A.; KESNER, J. S.; FOGWELL, R. L. Destruction of bovine ovarian follicles: effects on the pulsatile release of luteinizing hormone and prostaglandin F2 $\alpha$-induced luteal regression. Biology of Reproduction, v. 36, p. 523-529, 1987.

ING, N. H.; TORNESI, M. B. Estradiol up-regulates estrogen receptor and progesterone receptor gene expression in especific ovine uterine cells. Biology of Reproduction, v. 56, p. 1205-1215, 1997.

JABLONKA-SHARIFF, A.; GRASUL-BILSKA, A. T.; REMENDER, D. A. Growth and cellular proliferation of ovine corpora lutea throughout the estrous cycle. Endocrinology, v. 133, p. 1871-1879, 1993.

JOHNSON, F. F.; POYSER, N. L. Effects of mellitin on prostaglandin production by guineapig uterus. Journal of Reproduction and Fertility, v. 93, p. 577-585, 1991. 
JORGE, P.; BERTAN, C. M.; BERTHOLAZZI, A.; CASTRO E PAULA, L. A.; DA CUNHA, P. M.; GOISSIS, M.; BRESSAN, F. F.; MADUREIRA, E. H.; BINELLI, M. Efeitos Da Associação do $17 \beta$-estradiol $\left(\mathrm{E}_{2}\right)$ com o hormônio liberador de gonadotrofinas $(\mathrm{GnRH})$ e com gonadotrofina coriônica humana (hCG) na liberação de prostaglandina $\mathrm{F}_{2 \alpha}$ (PGF2 $\alpha$ ) em bovinos. In: CONGRESSO DE INTEGRAÇÃO EM BIOLOGIA DA REPRODUÇÃO, Anais do Congresso de Integração em Biologia da Reprodução, Ribeirão Preto, 2003, p.305.

JUENGEL, J. L.; NETT, T. M.; TANDESKI, T. M. Effect of luteinizing hormone and growth hormone on luteal development in hypophysectomized ewes. Endocrine, v. 3, p. 323326, 1995.

JUENGEL, J. L.; MEBERG, B. M.; TURZILLO, A. M. Hormonal regulation of mRNA encoding steroidogenic acute regulatory protein in ovine corpora lutea. Endocrinology, v. 136, p. 5423-5429, 1995.

KAHLERT, S.; NUEDLING, S.; VAN EICKELS, M.; VETTER, H.; MEYER, R.; GROHE, C. Estrogen receptor $\alpha$ rapidly activates the IGF-1 receptor pathway. Journal Biology of Chemistry, v. 275, p. 18447-18453, 2000.

KARSH, F. J.; NOVEROSKE, J. W.; ROCHE, J. F; NORTON, H. W.; NALBANDOV, A. V. Maintence of ovarian corpora lutea in absence of ovarian follicles. Endocrinology, v. 87, p. 1228-1235, 1970.

KATZENELLENBOGEN, B. S. Dynamics of steroid hormone receptor action. Ann Ver Physiology, v. 4, p. 17-35, 1980.

KELLY, M.J.; LEVIN, E.R. Rapid actions of plasma membrane estrogen receptors. Trends Endocrinol Metab., v. 12, p. 152-156, 2001.

KIM, J. J; FORTIER, M. A. A cell type specificity and protein kinase C dependency on the stimulation of prostaglandin $\mathrm{E}_{2}$ and prostaglandin $\mathrm{F} 2 \alpha$ production by oxytocin and plateletactivating factor in bovine endometrial cells. Journal of Reproduction and Fertility, v. 103, p. $239-247,1995$

KINDAHL, H.; EDQUIST, L. E.; BANE, A.; GRANSTROM, E. Blood levels of progesterone and 15-keto-13,14-dihydro-prostaglandin F2 alpha during the normal oestrous cycle and early pregnancy in heifers. Acta Endocrinology, v. 82, n. 1, p. 134-149, 1976.

KISHIMOTO, A.; MIKAWA, K.; HASHIMOTO, K. Limited proteolysis of protein kinase C subespecies by calcium-dependent neutral protease (calpain). Journal Biological Chemistry, v. 264, p. 4088-4092, 1989. 
KNICKERBOCKER, J. J.; THATCHER, J. J.; FOSTER, D. B.; WOLFENSON, D.; BARTOL, F. F.; CATON, D. Uterine production of PGF2 $\alpha$ in response to estradiol-17 $\beta$ in cyclic cattle. Annual Meeting of ASAS and CSAS. At University of Guelph, Ontario, Canada, v. 8-11, p. 364, 1982.

KNICKERBOCKER, J. J.; THATCHER, W. W.; FOSTER, D. B.; WOLFENSON, D.; BARTOL, F. F; CANTON, D. Uterine prostaglandin and blood flow responses to estradiol $17-\beta$ in cyclic cattle. Prostaglandins, v. 31, p. 757-767, 1986.

KOMBE, A.; SIROIS, J.; GOFF, A. K. Prolonged progesterone treatment of endometrial epithelial cells modifies the effect of estradiol on their sensitivity to oxytocin. Steroids, v. 68, n. 7-8, p. 651-658, 2003.

KOTWICA, G.; FRANCZAK, A.; OKRASA, S.; KOTWICA, J. Effect of na oxytocin antagonist $n$ prostaglandin F2 $\alpha$ secretion and the course of luteolysis in sows. Acta Veterinary Hungary, v. 47, n. 2, p. 249-262, 1999.

KOTWICA, J.; SKARZINSKY, D.; JAROSZEWKI, J.; WILLIAMS, G. L.; BOGACKI, M. Uterine secretion of prostaglandin F2 $\alpha$ stimulated by different doses of oxytocin and released spontaneousl during luteolysis in cattle. Reproduction Nutrition Development, v. 38, p. 217-226, 1998.

KOTWICA, J.; SKARZINSKY, D.; BOGACKI, M.; MELIN, P.; STAROSTKA, B. The use of an oxytocin antagonist to study the function of ovarian oxytocin during luteolysis in cattle. Theriogenology, v. 48, p. 1287-1299, 1997.

KRISANS, S. K. Cell compartmentalization of cholesterol biosynthesis. Annals of the New York Academy of Sciences, v. 27, p. 142-164, 1996.

KUIPER, G.G.; ENMARK, E.; PELTO-HUIKKO, M.; NILSSON, S.; GUSTAFSSON, J.A. Cloning of a novel receptor expressed in rat prostate and ovary. Proceeding Natl. Academic Sci, USA, v. 93, p. 5995-5930, 1996.

KUROKI, Y.; FUKUSHIMA, K.; KANDA, Y.; MIZUNO, K.; WATANABE, Y. Putative membrane-bound estrogen receptors possibly stimulate mitogen-activated protein kinase in the rat hippocampus. Europen Journal Pharmacology, v. 400, p. 205-209, 2000.

LAFRANCE, M.; GOFF, A. K. Control of bovine uterine prostaglandin F2 alpha release in vitro. Biology of Reproduction, v. 42, p. 188-193, 1990.

LAFRANCE, M.; GOFF, A. K. Effecs of $\mathrm{P}_{4}$ and estradiol 17- $\beta$ on oxytocin induced releasing of prostaglandin F2 $\alpha$ in heifers. Journal of Reproduction and Fertility, v. 82, p. 429-436, 1988. 
LAFRANCE, M.; GOFF, A. K. Effect of pregnancy on oxytocin-induced release of prostaglandin F2 $\alpha$ release in heifers. Biology of Reproduction, v. 33, p. 1113-1119, 1985.

LAMOTHE-ZAVALETA, C.; FREDRIKSSON, G.; KINDHAL, H. Reproductive performance of zebu cattle $n$ Mexico. 1. Sexual behaviour and seasonal influence on estrous cyclicity. Theriogenology, v. 36, n. 6, p. 887-896, 1991.

LEAVITT, W. W.; MaCDONALD, R. G.; OKULICZ, W. C. Hormonal regulation of estrogen and progesterone receptor systems. New York: Academic Press, 1983.

LEE, J. S.; SILVIA, W. J. Cellular mechanisms mediating the stimulation of ovine endometrial secretion of prostaglandin F2 $\alpha$ in response to oxytocin: role of phospholipase $\mathrm{A}_{2}$. Jounal of Endocrinology, v. 141, p. 491-496, 1994.

LEUNG, S. T.; WATHES, D. C. Oestradiol regulation of oxytocin receptor expression in cyclic bovine endometrium. Journal of Reproduction and Fertility, v. 119, p. 287-292, 2000 .

LIN, L. L.; LIN, L.; WARTMANN, M.; LIN, A. Y.; KNOPF, J. L.; SETH, A.; DAVIS, R. J. cPLA2 is phosphorilated and activated by MAP kinase. Cell, v. 72, p. 269-278, 1993.

LOUREIRO J. G. P.; CASTRO E PAULA, L. A.; MEMBRIVE, C. M. B.; DA CUNHA P. M.; MADUREIRA, E. H.; BINELLI, M. Caracterização de um sistema de perifusão para explantes de endométrio bovino: efeitos da dose e duração de tratamentos com forbol ester. In: ANAIS DO CONGRESSO DE INTEGRAÇÃO EM BIOLOGIA DA REPRODUÇÃO, 2001, Ribeirão Preto. Anais do Congresso de Integração em Biologia da Reprodução, 2001, p. 114.

MAMLUCK, R.; CHEN, D.; GREBER, Y.; DAVIS, J. S.; MEIDAN, R. Characterization of messenger ribonucleic acid expression forprosaglandin F2 alpha and luteinizing hormone receptors in various bovine luteal cell types. Biology of Reproduction, v. 58, n. 3, p. 849856, 1998.

MANN, G. E. Hormone control of prostaglandin F2 $\alpha$ production and oxytocin receptor concetrations in bovine endometrium in explant culture. Domestic Animal Endocrinology, v. 20, p. 217-226, 2001.

MANN, G. E.; LAMMING, G. E. Progesterone inhibition of the development of the luteolytic signal in cows. Journal of Reproduction and Fertility, v. 104, p. 1-5, 1995.

MASLAR, I. A.; POWERS-CRADDOCK, P.; ANSBACHER, R. Decidual prolactin production by organ cultures of human endometrium, effects of continuous and intermittent progesterone treatment. Biology of Reproduction, v. 34, n. 4, p. 741-750, 1986. 
MATTOS R.; GUZELOGLU, A.; BADINGA, L.; STAPLES, C. R.; THATCHER, W. W. Polyunsaturated fatty acids and bovine interferon-tau modify phorbol ester-induced secretion of prostaglandin F2 alpha and expression of prostaglandin endoperoxide synthase- 2 and phospholipase- $A_{2}$ in bovine endometrial cells. Biology of Reproduction, v. 69, p. 780-787, 2003.

MAWHINNEY, S.; ROCHE, J. F. Factors involved in oestrus cycle control in the bovine. In; SREENAN, J. M. (Ed.). Control of Reproduction in the cow. Luxembourg: EEC, 1978. p. 511-530.

McCRACKEN, J. A.; CUSTER, E. E; LAMSA, J. C. Luteolysis: a neuroendocrine mediated event. Phisiologycal Reviews, v. 79, n. 2, p. 263-323, 1999.

McCRACKEN, J. A.; SCHRAMM, W.; OKULICZ, W. C. Hormone receptor control of pulsatile secretion of PGF2 $\alpha$ from ovine uterus during luteolysis and its abrogation in early pregnancy. Animal Reproduction Science, v. 7, p. 31-55, 1984.

MEIDAN, R.; MILVAE, R.A.; WEISS, S. Intraovarian regulation of luteolysis. Journal of Reproduction and Fertility (Suppl), v. 54, p. 217-228, 1999.

MIRANDO, M. A.; BECKER, W. C.; WHITEAKER, S. S. Relationships among endometrial receptors, oxytocin-stimulated phosphoinositide hydrolysis and prostaglandin F2 $\alpha$ secretion in vitro, and plasma concentrations of ovarian steroids before and during corpus luteum regression in cyclic heifers. Biology of Reproduction, v. 48, p. 874-882, 1993.

MOREY, A.K.; RAZANDI, M.; PEDRAM, A.; HU, R-M; PRINS, B.; LEVIN, E.R. Estrogen and progesterone inhibit the stimulated production of endothelin-1: differential positive and negative regulatory mechanisms. Biochemical of Journal, v. 330, p. 1097-1105, 1998.

MOWA, C. N.; IWANAGA, T. Developmental changes of the oestrogen receptor-alpha and beta mRNA in the female reproductive organ of the rat na analysis by in situ hybridization. Jounal of Endocrinology, v. 167, n. 3, p. 363-369, 2000 b.

MOWA, C. N.; IWANAGA, T. Differential distribution of oestrogen receptor-alpha and betamRNA in the female reproductive organ of rats as reveled by in situ hybridization. Jounal of Endocrinology, v. 165, n. 1, p. 59-66, 2000a.

MURPHY, M. G.; ENRIGHT, W. J.; CROWE, M. A.; McCONNEL, K.; SPICER, L. J.; BOLAND, M. P.; ROCHE, J. F. Effect of dietary intake on pattern of growth of dominant follicles during the oestrus cycle in beef heifers. Journal of Reproduction and Fertility, v. 92, n. 2, p. 333-338, 1991. 
NALEFSKI, E. A.; SULTZNAN, L. A.; MARTIN, D. M.; KRIZ, R. W.; TOWLER, P. S.; KNOPF, J. L.; CLARK, J. D. Delineation of two functionally distinct domains of cytosolic phospholipase $\mathrm{A} 2$, a regulatory $\mathrm{Ca}\left({ }^{2+}\right)$ dependent lipid-binding domain and a $\mathrm{Ca}\left({ }^{2+}\right)-$ independent catalytic domain. Journal Biological of Chemical, n. 269, v. 27, p. 18239$18249,1994$.

NANCARROW, C. D.; BUCKMASTER, J.; CHAMELEY, W. Hormonal changes around oestrus in the cow. Journal Reproduction and Fertility, v. 32, n. 2, p. 320-321, 1973.

NEWCOMB, R.; BOOTH, W. D.; ROWSON, L. E. The effect of oxytocin treatment on the levels of prostaglandin F in the blood of heifers. Journal Reproduction and Fertility, v. 49, n. 1,1977 .

NISHIZUKA, Y. Intacellular signalling by hydrolysis of phospholipids and activation of protein kinase C. Science, v. 258, p. 607-614, 1992.

NISHIZUKA, Y.; TAKAI, Y.; KISHIMOTO, A.; KIKKAWA, U.; KAIBUCHI, K. Phospholipid turnover in hormone action. Recent Progress in Hormone Research, v. 40, p. 301-345, 1984.

NISWENDER, G. D. Molecular control of luteal secretion of progesterone. Reproduction, v. 123, p. 333-339, 2002.

NISWENDER, G. D.; JUENGEL, J. L.; SILVA, P. J. Mechanism controling the function and life span of the corpus luteum. Physiological Reviews, v. 80, p. 1-29, 2000.

OKUDA, K.; MIYAMOTO, Y.; SKARZYNSKI, D. J. Regulation of endometrial prostaglandin F (2alpha) synthesis during luteolysis and early pregnancy in cattle. Domestic Animal Endocrinology, v. 23, n. 1-2, p. 255-264, 2002.

OLSON, K. K.; ANDERSON, L. E.; WILTBANK, M. Actions of prostaglandin F2alpha and prolactin on intercellular adhesion molecule-1 expression and monocyte/macrophage accumulation in the rat corpus luteum. Biology of Reproduction, v. 64, n. 3, p. 890-897, 2001 .

PAPPAS, T.C.; GAMETCHU, B.; WATSON, C.S. Membrane estrogen receptors identified by multiple antibody labeling and impeded-ligand binding. FASEB Journal, v. 9, p. 404-410, 1995.

PERRET, S.; DOCKERY, P.; HARVEY, B. J. 17 $\beta$-Oestradiol stimulates capacitative $\mathrm{Ca}^{2+}$ entry In human endometrial cells. Molecular and Cellular Endocrinology, v. 176, p.77-84, 2001. 
PERRY, D. J.; AUSTIN, K. J.; HANSEN, T. R. 1999. Cloning of interferon-stimulated g17: the promoter and nuclear proteins that regulate transcription. Molecular Endocrinology, v. 13, p. 1197-1206, 1999.

PIETRAS, R. J.; SZEGO, C. M. Endometrial cell calcium and oestrogen action. Nature, v. 253, p. 357-359, 1975.

PIPER, P. J.; VANE, J. R.; WILLE, J. H. Inactivation of prostaglandin by the lungs. Nature, v. 225 , p. $600-604,1970$.

POYSER, N. L. Effects of various factors on prostaglandin synthesis by the guinea-pig uterus. Journal of Reproduction and Fertility, v. 141, p. 491-496, 1987.

PRITCHARD, J. Y.; SCHRICK, F. N.; INSKEEP, E. K. Relationship of pregnancy rate to peripheral concentrations of progesterone and estradiol in beef cows. Theriogenology, v. 42, p. 247-259, 1994.

PRU, J. K.; AUSTIN, J. K.; PERRY, D. J.; NIGHSWONGWER, A. M.; HANSEN, T. R. Production, purification and C-terminal sequencing of bioactive ISG17. Biology of Reproduction, v. 63, p. 619-628, 2000.

PRU, J. K.; AUSTIN, K. J.; HAAS, A. L.; HANSEN, T. R. Pregnancy and interferon- $\tau$ upregulate gene expression of members of the 1-8 family in bovine uterus. Biololy of Reproduction, v. 65, p. 1471-1480. 2001.

RAW, R. E.; SILVIA, W. J. Activity of phospholipase C and release of prostaglandin F2 $\alpha$ by endometrial tissue from ovariectomized ewes receiving progesterone and estradiol. Biology of Reproduction, v. 44, p. 404-412, 1991.

RAW, R. E.; SILVIA, W. J.; CURRY T. E. Effects of progesterona and estradiol on prostaglandin endoperoxide synthase in ovine endometrial tissue. Animal Reproduction Science, v. 40, p. 17-30, 1995.

RAZANDI, M.; PEDRAN, A.; GREENE, G. L.; LEVIN, E. R. Cell membrane and nuclear estrogen receptors (Ers) originate from a single transcript: studies of ER $\alpha$ and ER $\beta$ expressed in Chinese Hamster ovary cells. Molecular Endocrinology, v. 13, n. 2, p. 307-319, 1999.

RAZANDI, M.; PEDRAM, A.; LEVIN, E.R. Plasma membrane estrogen receptors signal to antiapoptosis in breast cancer. Molecular Endocrinology, v. 14, p. 1434-1447, 2000.

REDMER, D. A.; REYNOLDS, L. P. Angiogenesis in the ovary. Rev Reproduction, v. 1, n. 3, p. 182-192, 1996. 
REVELLI, A.; MASSOBRIO, M.; TESARIK, J. Nongenomic actions of steroid hormones in reproductive tissues. End Ver. , v. 19, p. 3-17, 1998.

RHODES, F. M.; DEA'ATH, G.; ENTWISTLE, K. W. Animal and temporal effects on ovarian follicular dynamics in Brahman heifers. Animal Reproduction Science, v. 38, n. 4, p. 265-277, 1995.

RICO, L.E.; THATCHER, W.W.; DROST, M.; WOLFENSON, D.; TERQUI, M. Plasma PGFM responses to estradiol injection in pregnant and cyclic cows. 73 rd Annual Meeting of Amer. Soc. Anim. Sci. At Carolina State University at Raleigh, North Carolina, v. 26-29, p. 363, 1981.

RILEY, S. C.; POYSER, N. L. Prostaglandin production by the guinea-pig endometrium: is calcium necessary? Journal of Endocrinology, v. 113, p. 463-472, 1987.

ROBINSON, M. J.; COBB, M. H. Mitogen-activated protein kinase pathways. Current Opinion in Cell Biology, v. 9, n. 2, p. 180-186, 1997.

ROBINSON, R. S.; MANN, G. E.; LAMMING, G. E.; WATHES, D. C. Expression of oxytocin, oestrogen and progesterone receptors in uterine biopsy samples throughout the oestrous cycle and early pregnancy in cows. Reproduction, v. 122, p. 965-979, 2001.

ROCHE, J. F.; MIHM, M.; DISKIN, M. G.; IRELAND, J. J. A review of regulation of follicle growth in cattle. Journal of Animal Science, v. 76, p. 16-29, 1998.

ROCHE, J. F.; PRENDERVILLE, D. J.; DAVIS, W. D. Calving rate following fixed-time insemination after a 12-day progesterone treatment in dairy cows, beef cows and heifers. Veterinary Record, v. 101, p. 417-418, 1977.

ROSENFELD, C. S.; YUAN, X.; MANIKKAM, M.; CALDER, M. D.; GARVERICK, H. Á. Sequencing, cloning, and localisation of bovine estrogen recptor-beta $(E R \beta)$ in reproductive tract of the cow. Biology of Reproduction, v. 58, p. 120, 1998. Supplement 1.

ROSENFELD, S. S.; XING, J.; CHEUNG, H. C.; BROWN, F.; KAR, S.; SWEENEY, H. L. Structural and kinetic studies of phosphorylation-dependent regulation in smooth muscle myosin. Journal Biological Chemistry, v. 273, n. 44, p. 28682-18690, 1998.

RUZYCKY, A. L.; KULICK A. Estrogen increases the expression of uterine protein kinase isozymes in a tissue specific manner. European Journal of Pharmacology, v. 17, n. 313, p. 257-263, 1996. 
SALFEN, B. E.; CRESSWELL, J. R.; XU, Z. Z.; BAO, B.; GAVERICK, H. A. Effects of the presence of a dominant follicle and exogenous estradiol on the duration of the luteal phase of boine estrous cycle. Journal of Reproduction and Fertility, v. 115, p. 15-21, 1999.

STATISTICAL ANALISYS SYSTEM. SAS user's guide: statistic. Release 6.03. Cary, NC: SAS, 1998.

SCHAMS, D.; BERISHA, B. Regulation of corpus luteum function in cattle- - na overview. Reproduction Domestic Animals, v. 39, n. 4, p. 241-251, 2004.

SCHIEVELLA, A. R.; REGIER, M. K.; SMITH, W. L.; LIN, L. L. Calcium-mediated translocation of cytosolic phospholipase A2 to the nuclear envelope and endoplasmic reticulum. Journal Biological Chemistry, v. 270, n. 51, p. 30749-30754, 1995.

SCHREY, M. P.; RUBIN, R. P. Characterization of a calcium-mediated activation of arachidonic acid turnover in adrenal phospholipids by corticotropin. Jounal of Biological Chemical, v. 254, p. 11234-11239, 1979.

SCHWARTZMAN, R. A.; CIDLOWSKI, J. A. Apoptosis, the biochemistry and molecular biology of programmed cell death. Endocrinology Rev., v. 14, n. 2, p. 133-151, 1993.

SHELDRICK, E.L.; FLICK-SMITH, H.C.; DOS SANTOS CRUZ, G.J. Oxytocin receptor binding activity in culture ovine endometrium. Journal of Reproduction and Fertility, v. 98, p. 521-528, 1993.

SHEMESH, M.; FREIDMAN, S.; GUREVICH, M.; STRAM, Y.; FIELDS, M.; SHORE, L. $\mathrm{S}$. Luteinizing hormone receptors and its mRNA in the bovine endometrium. Physiology Pharmacological, v. 47, p. 15-27, 1996. Supplement 1.

SHEMESH, M.; GUREVICH, M.; SHORE, L. S.; DAVIDSON, I.; FREIDMAN, S.; DOMBROVSKI, L. Regulation of ciclooxygenase and products of the ciclooxygenase pathway in the bovine uterus. Reproduction Domestic Animals, v. 31, p. 431-436, 1996.

SILVIA W. J.; HOMANICS, G. E. Role of phospholipase C in mediating oxytocin-induced release of prostaglandin F2 alpha from ovine endometrial tissue. Prostaglandins, v. 35, p. 535-548, 1988.

SILVIA, W. J.; LEE, J. S.; TRAMMERLL, D. S.; HAYES, S. H.; LOWBERGER, L. L.; BROCKMAN, J. A. Cellular mechanisms mediating the stimulation of ovine endometrial secretion of prostaglandin F2 $\alpha$ in response to oxytocin: role of phospholipase $\mathrm{C}$ and diacylglycerol. Journal Endocrinology, v. 141, p. 481-490, 1994. 
SILVIA, W. J.; LEWIS, G. S.; McCRACKEN, J. A.; THATCHER, W. W.; WILSON JR., L. Hormonal regulation of uterine secretion of PGF2 $\alpha$ durin luteolysis in ruminants. Biology of Reproduction, v. 45, p. 655-663, 1991.

SILVIA, W. J.; TAYLOR, M. L. Relationship between uterine secretion of prostaglandin F2 $\alpha$ induced by oxytocin and endogenous concentrations of estradiol and progesterone at three stages of the bovine estrous cycle. Journal of Animal Science, v. 67, p. 2347-2353, 1989.

SIMON, L. S. Role and regulation of cyclooxygenase-2 during inflammation. American Journal of Medicine, v. 106, p. 37-42, 1999.

SIROIS, J.; FORTUNE, J. E. Ovarian follicular dynamics during the estrous cycle in heifers monitored by real time ultrasonography. Biology of Reproduction, v. 39. n. 2, p. 308-317, 1988.

SKARZINSKY, D. J.; MIYAMOTO, Y.; OKUDA, K. Production of prostaglandin F2 $\alpha$ by cultured bovine endometrial cells in response to tumor necrosis factor $\alpha$ : a cell type specificity and intracellular mechanisms. Biology of Reproduction, v. 62, p. 1116-1120, 2000.

SKARZYNSKI, D.; BOGACKI, M.; KOTWICA, J. Involvement of ovarian steroids in basal and oxytocin-stimulated prostaglandin $\mathrm{F} 2 \alpha$ secretion from bovine endometrium in vitro. Theriogenology, v. 52, p. 385-397, 1999.

SLAMA, H.; VAILLANCOURT, D.; GOFF, A. K. Control of in vitro prostglandin F2 alpha and $\mathrm{E} 2$ synthesis by caruncular and a allantochorionic tissues from cows that calved normaly and those with retained fetal membranes. Domestic Animal Endocrinology, v. 11, n. 2, p. 175-185, 1994.

SMITH, S. K. Prostaglandins and growth factors in the endometrium. Bailliere's Clinical Obstetric Gynaecology, v. 3, p. 249-270, 1989.

SMITH, W. L. Prostanoid biosynthesis and mechanisms of action. Animal Journal Physiology, v. 263, p. 181-191, 1992.

SPENCER, T. E.; BECKER, W. C.; GEORGE, P.; MIRANDO, M. A.; OGLE, T. F.; BAZER, F. W. Ovine interferon- $\tau$ inhibits estrogen receptor up-regulation and estrogeninduced lutelysis in cyclic ewes. Endocrynology, v. 136, p. 4932-4944, 1995.

SREENAN, J. M.; MULVEHILL, P. The application of lonf and short-term progestagen treatments for oestrus cycle control in heifers. Journal of Reproduction and Fertility, v. 45, p. 867-869, 1975. 
STAGGS K. L.; AUSTIN K. J.; JOHNSON G. A.; TEIXEIRA M. G.; TALBOT, C. T.; DOOLEY, V. A.; HANSEN, T. R. Complex induction of bovine uterine proteins by interferon- $\tau$. Biology of Reproduction, v. 59, p. 297-283. 1998.

STEFANO, G. B.; CADET, P.; BRETON, C.; GOUMON, Y.; PREVOT, V.; DESSAINT, J. P.; BEAUVILLAIN, J. C.; ROUMIER, A. S.; WELTERS, I.; SALZET, M. Estradiolstimulated nitric oxide release in human granuloctes is dependent on intracellular calcium transients: evidence of a cell surface estrogen receptor. Blood, v. 95, p. 3951-3958, 2000.

SUH, D. Y.; HUNT, T. K.; SPENCER, E. M. Insulin-like growth factor-I reverses the impairment of wound healing induced by corticosteroids in rats. Endocrinology, v. 131, n. 5, p. 2399-2403, 1992.

TABIBZADEH, S. Molecular control of the implantation window. Human Reproduction Update, v. 4, p. 465-471, 1998.

TEZUKA, N.; ALI, M.; CHWALISZ, K. Changes in transcripts encoding calcium channel subunits of rat myometrium during pregnancy. Animal Journal Physiology, v. 269, p. 10081017, 1995.

THATCHER, W. W.; DRIANCOURT, M. A.; TERQUI, M.; BADINGA, L. Dynamics of ovarian follicular development in cattle following hysterectomy and during early pregnancy.

Domestic Animal Endocrinology, v. 8, n. 2, p. 223-234, 1991.

THATCHER, W. W.; GUZELOGLU, A.; MATTOS, R.; BINELLI, M.; HANSEN, T. R.; PRU, J. K. Uterine-conceptus interactions and reproductive failure in cattle. Theriogenology, v. 56, p. 1435-1450, 2001.

THATCHER, W. W.; TERQUI, M.; THIMONIER, J.; MAULEON, P. Effects of estradiol$17 \beta$ on peripheral plasma concentration of 15-keto-13, 14-dihydro PGF $2 \alpha$ and luteolysis in cyclic cattle. Prostaglandins, v. 3 1, n. 4, p. 745-756, 1986.

THATCHER, W. W.; TERQUI, M.; THIMONIER, J.; RAVAULT, J. P.; MAULEON, P. 15 keto PGF and hirmonal responses to injection of estradiol in heifers. Proc. S. Div. Amer. Soc. Anim. Sci., New Orleans, Lousiani, p. 43, 1979.

THORBURN, G. D.; COX, R. I.; CURRIE, W. B. Prostaglandin F and progesterone concentrations in the utero-ovarian venous plasma of the ewe during the oestrous cycle and early pregnancy. Journal Reproduction and Fertility, v. 18, p. 151-158, 1973. Supplement.

TYSSELING, K. A.; THATCHER, W. W.; BAZER, F. W.; HANSEN, P. J.; MIRANDO, M. A. Mechanisms regulating prostaglandin F2 $\alpha$ secretion from the bovine endometrium.

Journal of Dairy Science, v. 81, p. 382-389, 1998. 
VALLET, J. L.; BAZER, F. W.; ROBERTS, R. M. The effect of ovine trophoblast proteinone on endometrial protein secretion and cyclic nucleotides. Biology of Reproduction, v. 37, n. 5, p. 1307-1316, 1987.

VALLET, J. L.; BAZER, F. W. Effect of ovine trophoblast protein-1, oestrogen and progesterone on oxytocin- induced phosphatidylinositol turnover in endometrium of sheep. Journal of Reproduction and Fertility, v. 87, n. 2, p. 755-761, 1989.

VAN DEN BOSCH, H. Intracellular phospholipases. Biochemistry and Biophysics, v. 604, p. 191-199, 1980.

VESANAN, M.; ISOMA, V.; ALANKO, M.; VIHKO, R. Bovine uterine, cervical ans ovarian estrogen and progesterone receptor concentrations. Animal Reproduction Science, v. 26, p. 61-71, 1991.

VIANNA, J. H. M.; FERREIRA, A. M.; SÁ, W. F.; CAMARGO, L. S. A. Follicular dynamics in zebu cattle. Pesquisa Agropecuária Brasileira, Brasília, v. 35, n. 12, p. 2501 2509, 2000.

VILLA-GODOY, A.; IRELAND, J. J.; WORTMAN, J. A.; AMES, N. K.; FOGWEL, R. L. Luteal function in heifers following destruction of ovarian follicles. Journal of Animal Science, v. 53, p. 372, 1981. Supplement 1.

VOGT, W. Role of phospholipase A-2 in prostaglandin formation. In: GALI, G.; GALLI, G.; PROCELATTI, G. (Ed.). Advances in Prostaglandin and thromboxane Research. New York: Raven Press, 1978. v.3, p. 89-95.

WALKER, D.L.; WESTON, P.G.; HIXON. Influence of estradiol and progesterone withdrawal on the secretion of and the temporal correlation between pulses of oxytocin and prostaglandin F2 $\alpha$ in ewes. Biology of Reproduction, v. 56, p. 1228-1238, 1997.

WALLACE, J. M.; THOMPSON, M. G.; AITKEN, R. P.; CHAYNE M. A. Oxytocin receptor concentrations, inositol phosphhate turnover and prostaglandin release by endometrium from ewes induced to ovulate during the early postpartum period. Journal of Endocrinology, v. 136, p. 17-25, 1993.

WHATES, D. C.; MANN G. E.; PAYNE, J. J.; RILEY, P. R.; STEVENSON, K. R.; LAMMING, G. E. Regulation of oxytocin, oestradiol and progesterone receptor concentrations in different uterine regions by oestradiol, progesterone and oxytocin in ovariectomized ewes. Journal of Endocrinology, v. 151, p. 375-393, 1996.

WISHART, D. F. Observations on the oestrus cycle of the Friesian heifer. Veterinary Record, v. 90, n. 21, p. 595-597, 1972. 
XIAO, C. W.; GOFF, A. K. Hormonal regulation of estrogen andprogesterone receptors in cultured bovine endometrial cells, Journal of Reproduction and Fertility, v. 115, p. 101109, 1999.

XIAO, C.; LIU, W. J. M.; SIROIS, J.; GOFF, A. K. Regualtion of cyclooxigenase-2 and prostaglandin $\mathrm{F}$ synthase gene expression by steroid hormones and interferon- $\tau$ in bovine epithelial cells. Endocrinology, v. 139, p. 2293-2299, 1998.

XIAO, C.W.; MURPHY, B.D.; SIROIS, J.; GOFF, A.K. Down-regulation of oxytocininduced cyclooxygenase-2 and prostaglandin $\mathrm{F}$ synthase expression by interferon-tau in bovine endometrial cells. Biology of Reproduction, v. 60, p. 656-663, 1999.

YOUNG, S.; PARKER, P. J.; ULLRICH, A.; STABEL, S. Down-regulation of protein kinase $\mathrm{C}$ is due to an increase rate to degradation. Biochemistry Journal, v. 244, p. 775-779, 1987.

ZAMBETTI, G. P.; LEVINE, A. J. A comparision of the biological activities of wild-type and mutant p 53. FASEB Journal, v. 7, p. 855-865, 1993.

ZEITOUN, M. M.; RODRIGUEZ, H. F.; RANDEL, R. D. Effect of season on ovarian follicular dynamics in Brahman cows. Theriogenology, v. 45, p. 1577-1581, 1996.

ZELINSKI, M. B.; NOEL, B.; WEBER, D. W.; STORMSHAK, F. Characterization of cytoplasmic progesterone receptors in the ovine endometrium during proestrus and diestrus. Journal of Animal Science, v. 55, p. 376-383, 1982.

ZHANG, Q.; WU, W. X.; BRENNA, J. T.; NATHANIELSZ, P. W. The expression of cytosolic phospholipase $\mathrm{A}_{2}$ and prostalaglandin endoperoxide synthase in ovine maternal uterine and fetam tissues during late gestation and labor. Endocrinology, v. 137, p. 40104017, 1996. 
ANEXOS

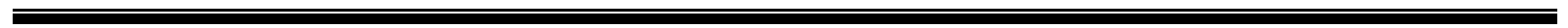




\section{ANEXO A1 PROTOCOLO DE CANULAÇÃO DA VEIA JUGULAR}

Os experimentos in vivo implicam na aquisição de amostras de sangue de vários animais a cada 30 minutos durante 12 horas. A técnica de canulação da veia jugular objetiva facilitar o procedimento de coleta das amostras, amenizar o mal estar aos animais e manter boas condições de higiene durante as coletas. Nesta técnica os procedimentos foram os seguintes:

A - Contenção do animal no tronco;

B - Elevação da cabeça do animal com o auxílio de um cabresto e uma corda;

C - Localização da veia jugular por palpação aproximadamente $20 \mathrm{~cm}$ abaixo da inserção da cabeça;

D - Realização de tricotomia e antissepsia na região do pescoço onde será inserido o cateter na veia jugular, com solução de iodo polvidine a 5\% (Figura 4, A);

E - Realização da punção da veia jugular com uma agulha 12G (Veterinary Luer Needle da Perfectum ${ }^{\circledR}$ ) esterilizada por imersão em álcool 70\%;

F - Introdução de um cateter com 40cm de comprimento (Fisher 14-170-15; Tygon $®$ ), 0,04 polegadas de diâmetro interno e 0,07 de diâmetro externo, no lúmen da agulha de 12G, permitindo que $20 \mathrm{~cm}$ do cateter fique exteriorizado (Figura 4, B). Esterelizar previamente o cateter por imersão em álcool 70\%;

G - Retirada da agulha de cateterização;

H - Inserção de uma agulha $18 \mathrm{G}(1,2$ x 40mm; com a ponta da agulha cortada reta) na extremidade externa do cateter;

I - Administração de 2,5mL de uma solução contendo 3,5\% de citrato de sódio, através de uma seringa acoplada à agulha de $18 \mathrm{G}$ inserida ao cateter (Figura 4, C); 
J - Realização da vedação na entrada da agulha acoplada ao cateter com um "plug" (tampa específica para a agulha que mantém o sistema fechado quando amostras de sangue não estão sendo coletadas);

K - Fixação do cateter a pele do animal com o auxílio de esparadrapos. Imediatamente após a saída do cateter pela pele, passar um esparadrapo formando um quadrado ao redor do cateter, fixar um dos lados do esparadrapo a pele do animal utilizando cola (Super Bonder Gel® - Loctite, Henkel Ltda);

L - Fazer a passagem do cateter através do orifício central do "patch" (bolsa de corvim com dimensões de $10 \times 10 \mathrm{~cm}$ com um sistema de velcro nas laterais e um orifício central em um dos lados) e fixar o "patch" à pele do animal com cola (Super Bonder Gel@ - Loctite, Henkel Ltda);

M - Remoção do "plug" e aspiração de $3 \mathrm{~mL}$ de sangue através da agulha inserida ao cateter com o auxílio de uma seringa de 10mL;

N - Realização de uma injeção de 2,5mL de citrato de sódio 3,5\% no cateter, em seguida encaixar o "plug" e fechar o "patch". Os ítens $\mathrm{M}$ e $\mathrm{N}$ objetivam verificar as condições de funcionamento da cânula (Figura 4, D);

O - Ao término do experimento fazer a retirada do cateter e o do "patch" com cuidadosos movimentos de tração. 

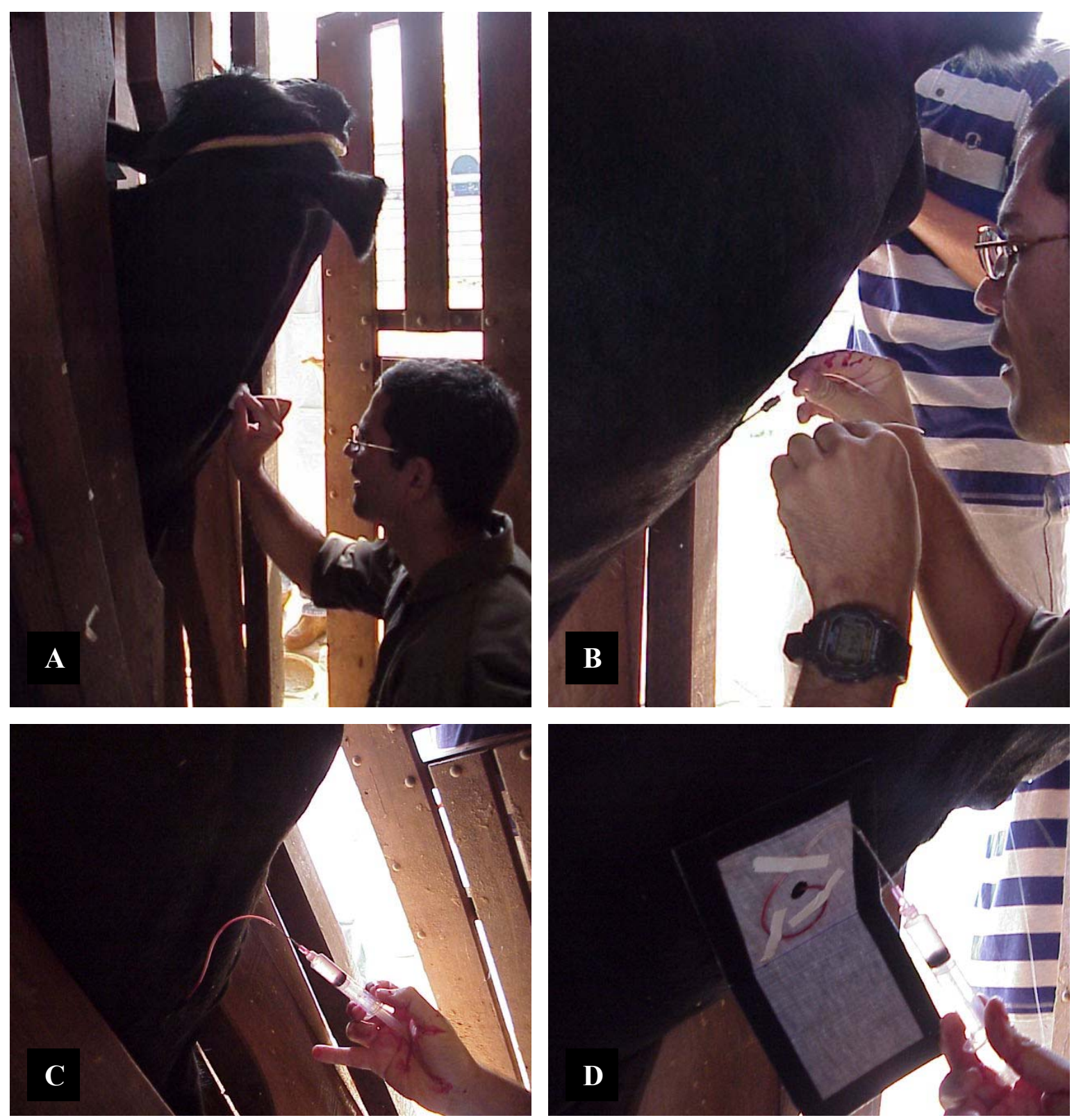

Figura 4 - Procedimento de canulação da veia jugular. A) Tricotomia e assepsia no local da inserção do cateter; B) Introdução da agulha e do cateter; C) Aplicação da solução de citrato de sódio a 3,5\%; D) "Patch" fixado a pele do animal e verificação das condições de funcionamento da cânula - Pirassununga - Jun 2002 


\section{ANEXO A2 PROTOCOLO DE COLETA SERIADA DE AMOSTRAS DE SANGUE}

Os experimentos in vivo objetivam avaliar o padrão da produção de PGFM em fêmeas bovinas em resposta aos diferentes tratamentos administrados. Para tanto se faz necessária a obtenção de amostras seriadas de plasma a cada 30 minutos durante um período de 12 horas para a mensuração das concentrações de PGFM por radioimunoensaio. A obtenção dessas amostras foi realizada conforme descrito abaixo.

A - Os animais são encaminhados a um estábulo tipo “tie stall”, contidos na argola por cabresto e corda, onde permanecem durante todo o tempo de realização do experimento, recebendo alimento volumoso e água a vontade;

B - Identificação de cada animal por uma cor de fita adesiva que deverá ser colada na parte externa do "patch" contendo o cateter, na estante de tubos para acondicionamento das amostras e nas seringas utilizadas para coleta de amostras de sangue e para a administração da solução de citrato de sódio 3,5\%;

C - Uma hora antes de iniciar a coleta seriada de amostras de sangue fazer a verificação do funcionamento dos cateteres injetando $3,5 \mathrm{~mL}$ citrato de sódio $3,5 \%$ na agulha conectada ao cateter;

D - Realização da coleta das amostras: abrir o "patch", desconectar o "plug" da agulha, aspirar $5 \mathrm{~mL}$ de sangue e desprezar, coletar aproximadamente $8 \mathrm{~mL}$ de sangue. Em seguida, injetar $3,5 \mathrm{~mL}$ de citrato de sódio $3,5 \%$ na agulha conectada ao cateter, conectar o "plug" a agulha e fechar o "patch". O mesmo procedimento é repetido a cada tempo de coleta;

E - Desprezar cuidadosamente o sangue coletado no tubo de vidro contendo $350 \mu \mathrm{L}$ de citrato de sódio a 30\%, fechar o tubo com tampa própria e inverter o tubo lentamente repetidas vezes para que o sangue seja vagarosamente misturado a solução de citrato;

F - Acondicionar o tubo contendo sangue em uma caixa de isopor contendo gelo $\left(4^{\circ} \mathrm{C}\right)$ 
G - No laboratório colocar os tubos nos adaptadores da centrífuga, os adaptadores devem ser pesados e equilibrados aos pares. Cada par de adaptadores com peso semelhante deverá ser posicionado na centrífuga de maneira oposta. Centrifugar as amostras a 2900 x g, durante 30 minutos, a $4^{\circ} \mathrm{C}$ (Centrífuga Sorvall ${ }^{\circledR}$ RC 3B Plus);

H - Com auxílio de pipetas Pasteur descartáveis, realizar a transferência do plasma para tubos plásticos $75 \times 12 \mathrm{~mm}$ com capacidade para $5 \mathrm{~mL}$ (Starstedt $\mathrm{n}^{\circ}$ 55-526). Transferir a mesma etiqueta do tubo de vidro para o tubo de plástico. Acondicionar as amostras de plasma à $-20^{\circ} \mathrm{C}$ até a realização dos radioimunoensaios para PGFM. 


\section{ANEXO A3 PROTOCOLO DA TÉCNICA DE RADIOIMUNOENSAIO PARA PGFM}

Essa técnica compreende várias etapas que serão descritas separadamente.

\section{OBTENÇÃO DE PLASMA LIVRE DE PGFM}

Para o ensaio de PGFM são utilizadas amostras de plasma, consequentemente, a curva padrão e as referências também devem conter um volume de plasma idêntico ao volume utilizado para as amostras, entretanto, utilizando-se de um plasma livre de PGFM. Considerando que o radioimunoensaio para PGFM é uma prática rotineira, foram obtidas quantidades de plasma suficientes para a realização de um grande número de ensaios. Há indicações que a sub-espécie bovina da qual é obtido o plasma livre de PGFM pode interferir no ensaio, segundo Marie-Joelle Thatcher (comunicação pessoal). Desta forma, obteve-se plasma livre de PGFM de animais Bos taurus taurus, Bos taurus indicus e Bos taurus taurus $\mathrm{x}$ Bos taurus indicus.

O procedimento para a obtenção de plasma livre de PGFM foram os seguintes:

A - Realização da estimativa do volume máximo de sangue a ser coletado de cada animal da seguinte maneira:

$$
\begin{aligned}
& \text { Peso do animal x } 7 \%=\mathrm{N} \text { (volume total de sangue estimado) } \\
& \qquad \mathrm{N} \times 10 \%=\text { Volume máximo que pode ser coletado }
\end{aligned}
$$

OBS: O volume de plasma obtido normalmente corresponde a 55 a $65 \%$ do volume de sangue coletado, entretanto dependerá da variação individual do hematócrito dos animais doadores de plasma e da eficiência do procedimento. 
B - Administração de duas injeções de Flunexin Meglumine (Banamine®, ScheringPlough Veterinária), na dose de $100 \mathrm{mg}$ para cada $45 \mathrm{~kg}$ de peso vivo, a primeira injeção $16 \mathrm{~h}$ antes da coleta e a segunda $4 \mathrm{~h}$ antes da mesma;

C - Contenção do animal no tronco, imobilização da cabeça com o auxílio de uma corda e puncionamento da veia jugular com uma agulha 40 x 20mm. Em seguida, acoplar um equipo a agulha e encaixá-lo em um erlenmeyer de $1000 \mathrm{~mL}$ contendo solução de citrato de sódio $10 \%$, na proporção de $1 \mathrm{~mL}$ para cada $20 \mathrm{~mL}$ de sangue. Durante a coleta o sangue deverá ser acondicionado a $4^{\circ} \mathrm{C}$. Inverter cuidadosamente o erlenmeyer para a homogeneização do sangue com a solução de citrato de sódio. Encaminhar o sangue coletado ao laboratório;

D - Realização da transferência de sangue para tubos de 50mL e centrifugação a 2900 $\mathrm{x} g$, durante 30 minutos a $4^{\circ} \mathrm{C}$ (Centrífuga Sorvall ${ }^{\circledR} \mathrm{RC} 3 \mathrm{~B}$ Plus);

E - Acondicionar o plasma em tubos plásticos de 50mL, previamente identificados. Armazenar a $-20^{\circ} \mathrm{C}$.

DILUIÇÃO DE PGFM, PREPARAÇÃO DE SOLUÇÕES ESTOQUE E DE REFERÊNCIAS PARA RADIOIMUNOENSAIOS

Várias soluções são requeridas para a realização do radioimunoensaio para PGFM. Para a elaboração da curva padrão é necessária uma solução estoque de PGFM, que será posteriormente diluída em série. Também é requerido o preparo de referências diluindo-se determinadas quantidades PGFM em plasma livre de PGFM. Para tanto, os procedimentos são os seguintes:

A - Preparação da solução estoque com $1 \mu \mathrm{g} / \mathrm{mL}$ de PGFM: diluir um mg de PGFM (Sigma, D4143) em 1mL de etanol absoluto, constituindo uma solução $1 \mathrm{mg} / \mathrm{mL}$ (solução 
estoque A). Diluir a solução estoque A em solução Tris-HCl 0,05 M, pH 7,5 contendo 0,1g/L $\mathrm{NaNO}_{3}$ (Tampão Tris-HCl) de maneira que se estabeleça uma concentração de $1 \mu \mathrm{g} / \mathrm{mL}$ (solução estoque B). Subdividir a solução estoque B em alíquotas de $50 \mu 1$ e armazenar a $-20^{\circ} \mathrm{C}$. Tal solução é utilizada como solução inicial para a preparação de curvas padrões nos radioimunoensaios para PGFM;

B - Preparação das referências para radioimunoensaio de PGFM: preparar soluções contendo 50, 100, 500 e 1000pg/mL de PGFM utilizando-se da solução estoque B diluída em plasma livre de prostaglandinas. Foram preparadas as referências em cada uma das concentrações em plasma de animais Bos taurus taurus, Bos taurus indicus e Bos taurus taurus x Bos taurus indicus. Alíquotar as referências e armazenar a $-20^{\circ} \mathrm{C}$.

DILUIÇÃO E DETERMINAÇÃO DA CAPACIDADE DE LIGAÇÃO DE ANTICORPO ANTIPGFM PARA RADIOIMUNOENSAIOS

O anticorpo utilizado nos radioimunoensaios de PGFM foi gentilmente doado pelo Prof. Dr. William Thatcher da Universidade da Florida. Tal anticorpo estava liofilizado e acondicionado em microtubos. Seguindo as instruções do doador, o mesmo foi reconstituído em $500 \mu 1$ de água destilada, gerando uma solução com diluição final de 1:100.

Para a realização do radioimunoensaio para PGFM recomenda-se que a diluição do anticorpo promova uma capacidade de ligação de aproximadamente $30 \%$. Assim, foram realizados estudos preliminares testando as seguintes diluições da solução de anticorpo para PGFM: 1:1000, 1:2000, 1:4000, 1:8000 e 1:16000. Os testes foram executados seguindo-se o procedimento para radioimunoensaio para PGFM descrito abaixo e a diluição da solução de anticorpo determinada como a mais adequada foi 1: 7000. Tal diluição foi utilizada em todos os ensaios subseqüentes. 


\section{DETERMINAÇÃO DA CONCENTRAÇÃO DE 12, 13 DIHIDRO-15CETO - PROSTAGLANDINA} F2 $\alpha$ (PGFM) NO PLASMA POR RADIOIMUNOENSAIO

O princípio da técnica de radioimunoensaio baseia-se em uma reação não covalente e estável do tipo antígeno-anticorpo. Estima-se a quantidade de hormônio (antígeno) na amostra usando-se uma quantidade conhecida do mesmo marcado com o isótopo trício ( $\left.{ }^{3} \mathrm{H}-\mathrm{PGFM}\right)$. A PGFM marcada e não marcada se liga competitivamente a uma quantidade limitada de anticorpo. A radioatividade da fração de antígeno marcado que se liga às moléculas de anticorpo é então detectada por um aparelho de Contagem de Radiação Beta (Wallac ${ }^{\circledR} 1409$ DAS, Liquid Scintillation Counter). Uma curva padrão é elaborada com quantidades conhecidas do ligante de interesse e uma equação de regressão é obtida relacionando-se as quantidades de ligante com as contagens radiativas obtidas. A concentração de ligante nas amostras é obtida substituindo o valor da contagem na equação de regressão.

O radioimunoensaio para PGFM usando o radioisótopo Trício é realizado em duas etapas. Na primeira etapa, é realizado o ensaio propriamente dito onde a curva padrão e as amostras são pipetadas e colocadas em tubos de ensaio acrescidos de solução tampão TrisHCL 0,05M com pH 7,5, anticorpos e PGFM marcada com ${ }^{3} \mathrm{H}$. Esses tubos são então incubados por aproximadamente 16 horas a $4^{\circ} \mathrm{C}$. Após esse período, procede-se a separação do antígeno ligado do não-ligado aos anticorpos, utilizando-se uma solução de polietileno glicol (PEG) a 30\%. O protocolo utilizado é semelhante ao proposto pelo Dr. William Thatcher da Universidade da Flórida.

Antes de iniciar os ensaios preparar uma planilha contendo o número dos tubos com a identificação dos conteúdos. As amostras devem ser divididas eqüitativamente entre os ensaios equivalente a um determinado experimento, animais e número da amostra de plasma coletada em série dentro de um mesmo ensaio. 
Considerando que o ensaio é realizado com amostras de plasma, todos os tubos do ensaio (curva padrão, NSB, TC e Bo) devem receber plasma, entretanto livre de PGFM (plasma de animais previamente tratados com flunixim meglumine, conforme descrito acima). Todas as amostras são mensuradas em duplicata. A técnica validada procede da seguinte maneira:

A - Preparar uma curva padrão de PGFM (Sigma D4143) em tampão Tris-HCl 0.05M pH 7,5 (Fisher BB153-1) nas seguintes concentrações: 15.1; 31.2; 62.5; 125; 250; 500; 1000; 2000; 4000 e $8000 \mathrm{pg} / \mathrm{mL}$ ) a partir da solução estoque B contendo $1 \mu . \mathrm{g} / \mathrm{mL}$ de PGFM. Para cada tubo são utilizados $100 \mu \mathrm{L}$, assim em duplicata utiliza-se $200 \mu \mathrm{L}$, de cada uma das soluções. Preparar as soluções da seguinte maneira: $8000 \mathrm{pg} / \mathrm{mL}(1984 \mu \mathrm{L}$ de Tris- $\mathrm{HCl}+16 \mu \mathrm{L}$ da solução estoque com $1 \mu \mathrm{g} / \mathrm{mL}$ de PGFM); 4000pg/mL $(1000 \mu \mathrm{L}$ de Tris-HCl $+1000 \mu \mathrm{L}$ da solução com $8000 \mathrm{pg} / \mathrm{mL}$ de PGFM); $2000 \mathrm{pg} / \mathrm{mL}(1000 \mu \mathrm{L}$ de Tris-HCl $+1000 \mu \mathrm{L}$ da solução com 4000pg/mL de PGFM); $1000 \mathrm{pg} / \mathrm{mL}(1000 \mu \mathrm{L}$ de Tris-HCl $+1000 \mu \mathrm{L}$ da solução com 2000pg/mL de PGFM); $500 \mathrm{pg} / \mathrm{mL}(1000 \mu \mathrm{L}$ de Tris-HCl $+1000 \mu \mathrm{L}$ da solução com $1000 \mathrm{pg} / \mathrm{mL}$ de PGFM); $250 \mathrm{pg} / \mathrm{mL}(1000 \mu \mathrm{L}$ de Tris-HCl $+1000 \mu \mathrm{L}$ da solução com $500 \mathrm{pg} / \mathrm{mL}$ de PGFM); $125 \mathrm{pg} / \mathrm{mL}(1000 \mu \mathrm{L}$ de Tris- $\mathrm{HCl}+1000 \mu \mathrm{L}$ da solução com $250 \mathrm{pg} / \mathrm{mL}$ de PGFM); $62,5 \mathrm{pg} / \mathrm{mL}(1000 \mu \mathrm{L}$ de Tris- $\mathrm{HCl}+1000 \mu \mathrm{L}$ da solução com $125 \mathrm{pg} / \mathrm{mL}$ de PGFM); 31,25pg/mL (1000 $\mu \mathrm{L}$ de Tris-HCl + 1000 $\mu \mathrm{L}$ da solução com 62,5pg/mL de PGFM) e $15,12 \mathrm{pg} / \mathrm{mL}(1000 \mu \mathrm{L}$ de Tris- $\mathrm{HCl}+1000 \mu \mathrm{L}$ da solução com $31,25 \mathrm{pg} / \mathrm{mL}$ de PGFM);

B - O número máximo de tubos a serem colocados em um ensaio é de 198 tubos. Assim, para um ensaio completo numerar tubos de vidro 12 x $75 \mathrm{~mm}$ revestidos com borosilicato (Fisher 14-961-26) com os números de 1 a 198;

C - Pipetar $200 \mu \mathrm{L}$ de Tris- $\mathrm{HCl}$ nos tubos referentes ao NSB (No Specific Binding; tubos 1 a 3$)$; 
D - Pipetar $500 \mu \mathrm{L}$ de Tris- $\mathrm{HCl}$ nos tubos referentes ao TC (Total Count; tubos 4 a 6);

E - Pipetar $100 \mu \mathrm{L}$ de Tris-HCl nos tubos referentes ao Bo (Binding; tubos 7 a 9);

F - Pipetar 100 $\mu \mathrm{L}$ das soluções referentes à curva: 15.1 (tubos 10 e 11); 31.2 (tubos 12 e 13); 62.5 (tubos 14 e 15); 125 (tubos 16 e 17); 250 (tubos 18 e 19); 500 (tubos 20 e 21); 1000 (tubos 22 e 23); 2000 (tubos 24 e 25); 4000 (tubos 26 e 27); 8000pg/mL (tubos 28 e 29);

G - Pipetar $300 \mu \mathrm{L}$ das soluções de referência: $50 \mathrm{pg} / \mathrm{mL}$ (tubos 30 e 31), 100pg/mL (tubos 32 e 33), 500pg/mL (tubos 34 e 35) e 1000 pg/mL (tubos 36 e 37);

H - Pipetar $300 \mu \mathrm{L}$ de cada amostra a ser mensurada em duplicata dos tubos 38 ao 190;

I - Pipetar $300 \mu \mathrm{L}$ das soluções de referência: $50 \mathrm{pg} / \mathrm{mL}$ (tubos 191 e 192), 100pg/mL (tubos 193 e 194), 500pg/mL (tubos 195 e 196) e 1000 pg/mL (tubos 197 e 198);

J - Pipetar $300 \mu \mathrm{L}$ de plasma livre de PGFM nos tubos NSB (tubos 1 a 3), Bo (tubos 7 a 9) e nos referentes à curva padrão (tubos 10 a 29);

$\mathrm{K}$ - Pipetar $100 \mu \mathrm{L}$ de Tris-HCl nos tubos contendo às referências e amostras a serem mensuradas (tubos 30 ao 198);

L - Preparar uma solução de anticorpo para PGFM utilizando a seguinte fórmula: Volume inicial (quantidade da solução de Ac 1/100 a ser colocada na solução) x Concentração inicial $(1 / 100)$ = Volume final (quantidade de solução contendo anticorpo que deverá ser preparada para todo o ensaio) x Concentração final (1/7000). Para um ensaio com 198 tubos, preparar um volume final de $20 \mathrm{~mL}$, a partir da solução de anticorpo reconstituída em $500 \mu \mathrm{L}$ de $\mathrm{ddH}_{2} \mathrm{O}$ (concentração inicial de 1/100), sendo pré-deerminado uma concentração final de 1/7000. Assim, temos a seguinte fórmula: Vi x 1/100=20000 x 1/7000, sendo o $\mathrm{Vi}=285,7 \mu \mathrm{L}$. Diluir $285,7 \mu \mathrm{L}$ da solução de anticorpo $1 / 100)$ em $19.714,3 \mu \mathrm{L}$ de Tris-HCl; 
M - Preparar uma solução radioativa de PGFM marcada com trício com uma concentração tal que os tubos TC tenham aproximadamente 15000 desintegrações por minuto (DPM);

$\mathrm{N}$ - Pipetar $100 \mu \mathrm{L}$ da soução de anticorpo previamente preparada em todos os tubos, exceto nos NSB e TC (tubos 1 a 6). Homogeneizar o conteúdo dos tubos com velocidade 8 durante 1 minuto (Standard Multi-Tube Vortexer Modelo 58816-115; WWR Scientific Products). Deixar os tubos em temperatura ambiente durante 30 minutos;

O - Adicionar $100 \mu \mathrm{L}$ da solução de PGFM marcada com trício em todos os tubos. Homogeneizar o conteúdo dos tubos com velocidade 8 durante 1 minuto (Standard MultiTube Vortexer Modelo 58816-115; WWR Scientific Products). Deixar os tubos em temperatura ambiente durante 1 hora. Em seguida, incubar os tubos a $4^{\circ} \mathrm{C}$ durante 12 a 18 horas;

$\mathrm{P}$ - Após o período de incubação separar os tubos TC e acondicionar os mesmos a $4^{\circ} \mathrm{C}$. Adicionar $750 \mu \mathrm{L}$ de uma solução de PEG 30\% em todos os tubos, exceto nos tubos TC. Homogeneizar o conteúdo dos tubos com velocidade 8 durante 1minuto (Standard Multi-Tube Vortexer Modelo 58816-115; WWR Scientific Products). Centrifugar a 2900 x g, durante 30 minutos à $4^{0} \mathrm{C}$ (Centrífuga Sorvall® RC 3B Plus);

Q - Colocar todos os tubos em "racks" próprias e invertê-los desprezando o sobrenadante. Deixar a "racks" invertidas sobre um papel absorvente durante 10 minutos;

R - Adicionar $750 \mu \mathrm{L}$ de Tris- $\mathrm{HCl}$ em cada um dos tubos. Homogeneizar o conteúdo dos tubos com velocidade 8 durante 1minuto (Standard Multi-Tube Vortexer Modelo 58816115; WWR Scientific Products). Em seguida, adicionar $750 \mu \mathrm{L}$ de PEG 30\% (Fisher Scientific, BP233-1) a cada um dos tubos. Homogeneizar o conteúdo dos tubos com velocidade 8 durante 1minuto (Standard Multi-Tube Vortexer Modelo 58816-115; WWR 
Scientific Products). Centrifugar a 2900 x g, durante 30 minutos à $4^{0} \mathrm{C}$ (Centrífuga Sorvall ${ }^{\circledR}$ RC 3B Plus);

$\mathrm{S}$ - Colocar todos os tubos em racks próprias e invertê-los desprezando o sobrenadante. Deixar a racks invertidas sobre um papel absorvente durante 10 minutos;

$\mathrm{T}$ - Adicionar em $1 \mathrm{~mL}$ de Tris- $\mathrm{HCl}$ em todos os tubos agora incluindo os TC. Homogeneizar o conteúdo dos tubos com velocidade 8 durante 3 minutos (Standard MultiTube Vortexer Modelo 58816-115; WWR Scientific Products);

U - Inverter o conteúdo dos tubos de vidro em tubos de plástico para a contagem (Sarstedt 58536), previamente numerados de 1 a 198 e acomodados em seqüência numérica nas estantes do contador. Imediatamente antes da inversão homogeneizar o conteúdo do tubo a ser invertido (Fisher Vortex Genie 2 Modelo 12-812; Fisher Scientific). Os tubos de plástico devem ser acomodados nas "racks" específicas do contador de Radiação Beta, em ordem numérica de tubos e racks, para posterior leitura da radioatividade. Adicionar $4,5 \mathrm{~mL}$ de $1,2,4$ trimetilbenzeno (Scintiverse ${ }^{\mathrm{TM}}$ Bio HP; Fisher Scientfic, SX 14-4) aos tubos de cintilação, tal procedimento deve ser realizado dentro da capela. Fechar os tubos de plástico com tampas próprias e homogeneizar com movimentos de inversão.

V - Programação do contador para a contagem da quantidade de DPM presente em cada tubo e realização da contagem.

X - Transferência dos resultados para uma planilha própria do programa "Quatro Pro". Este programa relaciona a curva padrão (concentração de PGFM em pg/mL) com as contagens em DPM. Com a curva padrão é elaborada uma equação de regressão. A concentração de ligante nas amostras é obtida substituindo o valor da contagem na equação de regressão. 
ANEXO A4 PROTOCOLO DE INCUBAÇÃO DE TECIDO ENDOMETRIAL EM BANHOMARIA COM AGITAÇÃO

A técnica descrita por Burns et al. (1997) baseia-se na cultura de explantes endometriais em tubos acondicionados em um banho-maria com agitação. No presente estudo os explantes foram obtidos de novilhas no $17^{\circ}$ dia do ciclo estral, do corno uterino ipsolateral ao corpo lúteo. Os procedimentos foram os seguintes:

A - Imediatamente antes do abate da fêmea coletar uma amostra de sangue, centrifugar a 2900 x g, durante 30 minutos a $4^{\circ} \mathrm{C}$ (Centrífuga Sorvall® RC 3B Plus). Armazenar o plasma a $-20^{\circ} \mathrm{C}$ para uma posterior mensuração das concentrações plasmáticas de progesterona por radioimunoensaio;

B - Após o abate do animal localizar e isolar o sistema genital, acondicionar em gelo e encaminhar imediatamente ao laboratório;

C - Em capela de fluxo laminar isolar o corno uterino ipsolateral ao corpo lúteo. Seccionar o corno uterino longitudinalmente a face mesometrial, para a exposição do endométrio. Dissecar o endométrio isolando-o do miométrio. Separar fragmentos de endométrio das regiões intercarunculares e acondicioná-los em placas de Petri contendo Meio Bicarbonato Krebs-Hensleit [KHB; $118 \mathrm{mM} \mathrm{NaCl}$ (Fisher BP358), 4.7mM KCl (Fisher BP3661), 2.56mM CaCl 2 (Fisher C614-500), 1.13mM $\mathrm{MgCl}_{2}$ (Fisher BP214-500), 25mM $\mathrm{NaHCO}_{3}$ (Fisher BP328-1), 1.15mM NaH${ }_{2} \mathrm{PO}_{4}$ (Fisher BB332-500), 5.55mM glucose (Sigma G6152), 20mM Hepes (Fisher BP310-100) e 0.013mM de vermelho fenol (Sigma P5530); $\mathrm{pH} 7.4]$

D - Separar e pesar individualmente os explantes endometriais, de maneira que tenham de 80 a 100mg. Acondicionar os explantes em tubos para cultura de 12 x 75mm, revestidos com borosilicato (Fisher 14-961-26) previamente esterelizados por autoclavagem, contendo 
$0,5 \mathrm{~mL}$ de meio $\mathrm{KHB}$. Incubar em banho-maria com agitação de $40 \mathrm{rpm}$, a $37^{\circ} \mathrm{C}$ durante 1 hora (Dubnoff Shaker - Precision 600021382);

E - Após 1 hora de incubação realizar a primeira lavagem do tecido endometrial da seguinte maneira: descartar o meio, colocar $0,5 \mathrm{~mL}$ de $\mathrm{KHB}$ em cada tubo, descartar o meio novamente e adicionar $0,5 \mathrm{~mL}$ de KHB fresco em cada tubo. Incubar os explantes novamente em banho-maria com agitação de $40 \mathrm{rpm}$, a $37^{\circ} \mathrm{C}$ por 1 hora;

F - Após 1 hora descartar o meio KHB e realizar nova lavagem dos explantes, repetindo o procedimento anterior (item E). Em seguida, adicionar $1 \mathrm{~mL}$ do meio controle (KHB) ou KHB suplementado com os diferentes tratamentos;

G - Remover amostras de $100 \mu \mathrm{L}$ do meio de cultura nos tempos 0 e 60 minutos após a adição dos tratamentos. Armazenar em microtubos previamente identificados a $-20^{\circ} \mathrm{C}$ para a posterior mensuração das concentrações de PGF2 $\alpha$ por radioimunoensaio.

Os procedimentos para a incubação dos explantes endometriais estão ilustrados nas Figuras 5 e 6 . 


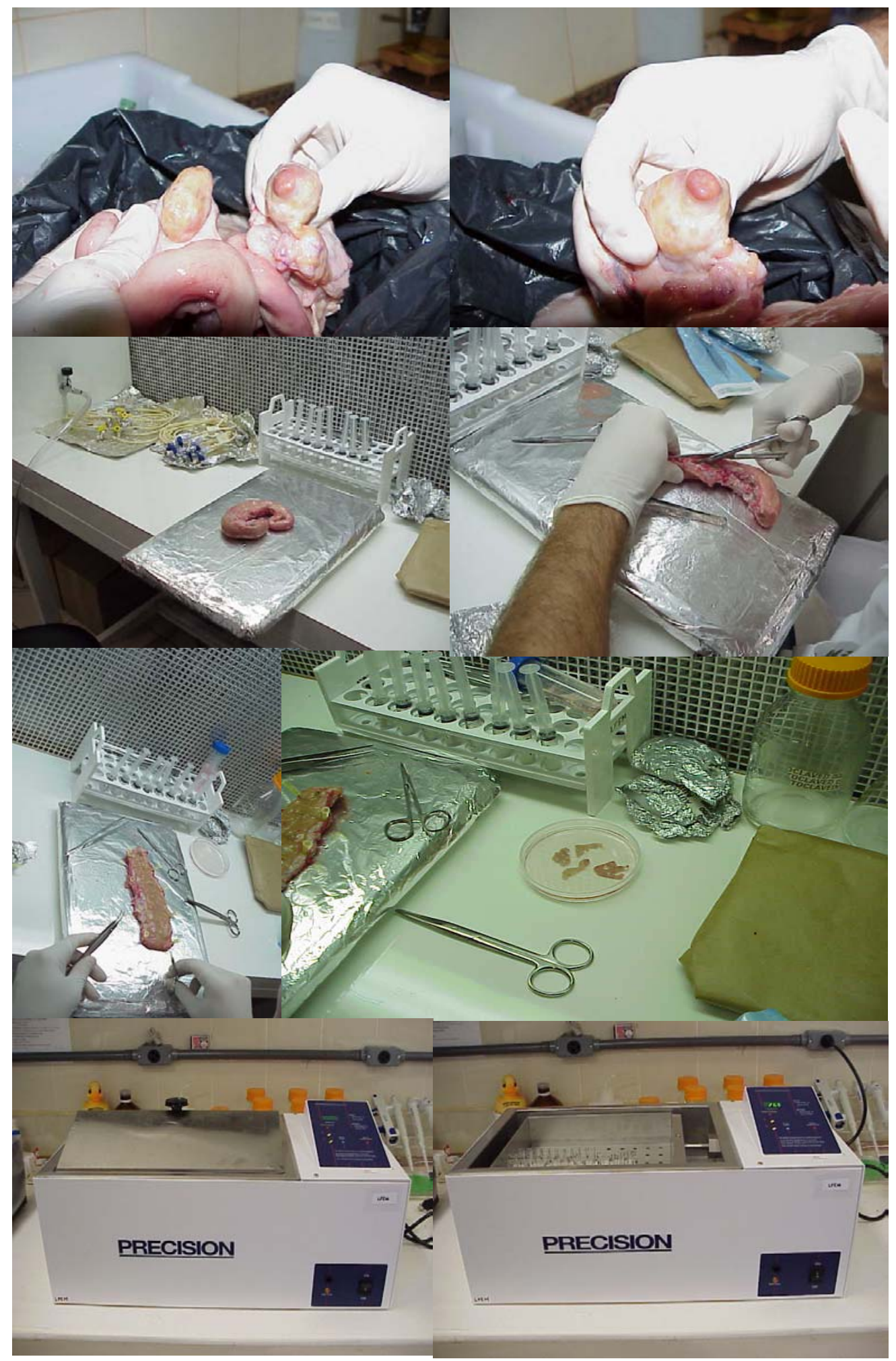

Figura 5 - Procedimentos de incubação dos explantes edometriais em banho-maria com agitação (Dubnoff Shaker) - Pirassununga - Jan. 2002 a Dez. 2003 


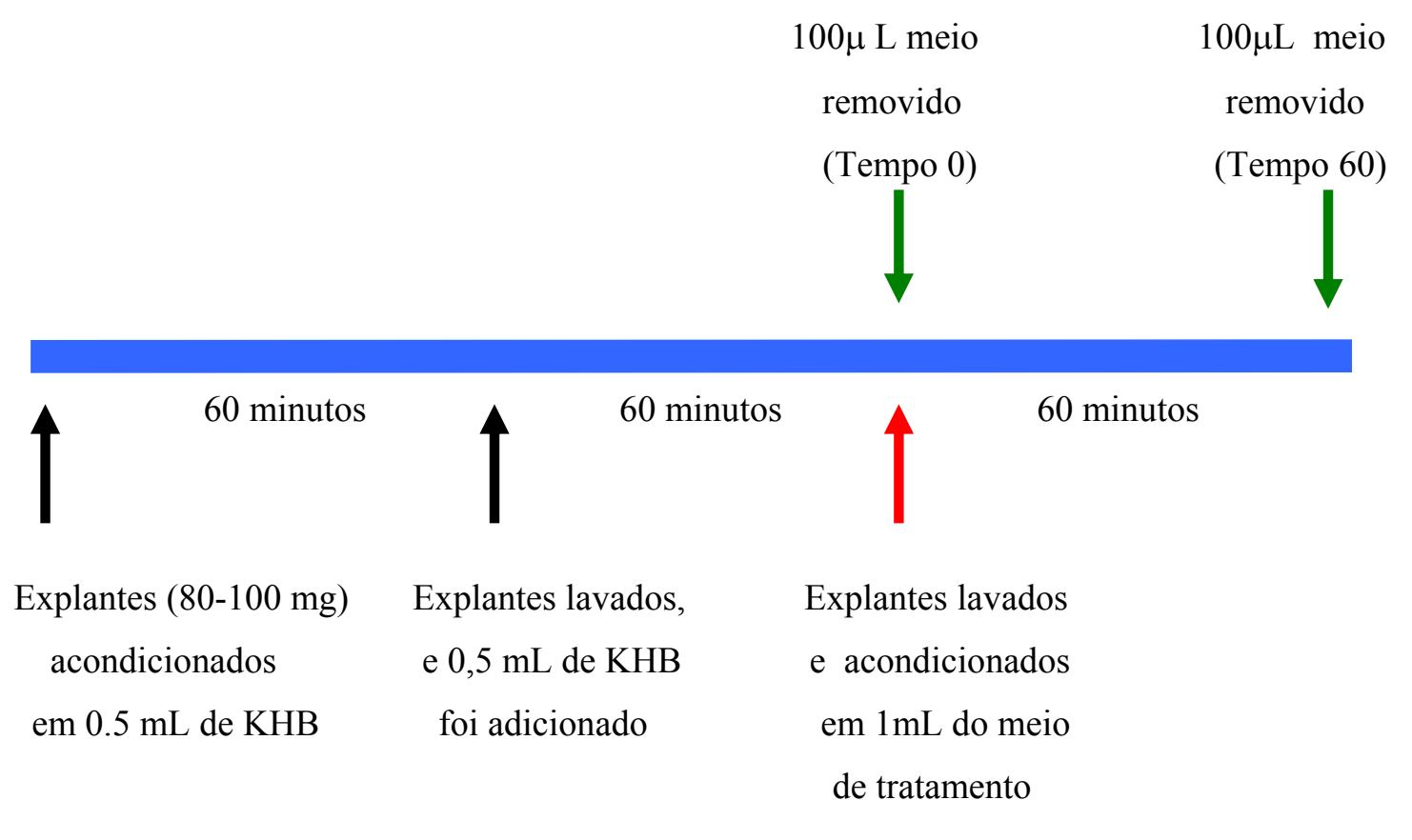

Figura 6 - Esquema do sistema de cultura de tecido endometrial por incubação Pirassununga - Jan 2002 a Dez. 2003 


\section{ANEXO A5 PROTOCOLO DA TÉCNICA DE RADIOIMUNOENSAIO PARA PGF2 $\alpha$}

O princípio da técnica de radioimunoensaio baseia-se em uma reação não covalente e estável do tipo antígeno-anticorpo. Estima-se a quantidade de PGF2 $\alpha$ (antígeno) na amostra utilizando-se uma quantidade conhecida do mesmo marcado com o isótopo trício $\left({ }^{3} \mathrm{H}\right.$ PGF2 $\alpha$ ). A PGF2 $\alpha$ marcada e não marcada se liga competitivamente a uma quantidade limitada de anticorpo. A radioatividade da fração de antígeno marcado que se liga às moléculas de anticorpo é então detectada por um aparelho de Contagem de Radiação Beta (Wallac ${ }^{\circledR} 1409$ DAS). Uma curva padrão é elaborada com quantidades conhecidas do ligante de interesse e uma equação de regressão é obtida relacionando-se as quantidades de ligante com as contagens radiativas obtidas. A concentração de ligante nas amostras é obtida substituindo o valor da contagem na equação de regressão.

A técnica de radioimunoensaio para a mensuração das concentrações de PGF2 $\alpha$, utilizando o radioisótopo trício $\left({ }^{3} \mathrm{H}\right)$, foi realizada em duas etapas. Na primeira etapa, foi realizado o ensaio propriamente dito onde a curva padrão, referências e as amostras de meio de cultivo foram pipetadas e colocadas em tubos as quais foram acrescidos de solução tampão Tris-HCl, anticorpos e antígeno marcado com ${ }^{3} \mathrm{H}$. Esses tubos foram incubados por 12 a 16 horas a $4^{\circ} \mathrm{C}$. Na segunda etapa, foi realizada a separação do antígeno ligado do não-ligado aos anticorpos utilizando uma solução contendo carvão ativado e Dextran. O protocolo utilizado é semelhante ao proposto pelo Dr. William Thatcher da Universidade da Flórida. Os passos que compreendem a técnica serão detalhadamente descritos. 


\section{PREPARAÇÃO DE SOLUÇÕES ESTOQUE E DE REFERÊNCIAS PARA PGF2 $\alpha$}

Várias soluções são requeridas para a execução da técnica de radioimunoensaio para PGF2 $\alpha$. Para a elaboração da curva padrão e das referências são preparadas diferentes soluções contendo PGF2 $\alpha$. Os procedimentos foram os seguintes:

A - Preparação de uma solução estoque de PGF2 $\alpha$ : diluição de um mg de PGF2 $\alpha$ (Sigma - P0424) em 1mL de etanol absoluto constituindo uma solução $1 \mathrm{mg} / \mathrm{mL}$ (solução estoque A). Diluição da solução estoque A em solução tampão Tris-HCl $0.05 \mathrm{M}$ (Fisher BB153-1) com pH 7,5 de maneira que constitua uma concentração de $1 \mu \mathrm{g} / \mathrm{mL}$ de PGF2 $\alpha$ (solução estoque B), fazer alíquotas de $50 \mu \mathrm{L}$ e armazenar a $-20^{\circ} \mathrm{C}$. Tal solução foi utilizada como solução inicial para a preparação de rotina da curva padrão nos radioimunoensaios para PGF2 $\alpha$;

B - Preparar as soluções de referência para radioimunoensaio de PGF2 $\alpha$ : preparar soluções contendo 250, 1000 e $3500 \mathrm{pg} / \mathrm{mL}$ de PGF2 $\alpha$ a partir da solução estoque B $(1 \mu \mathrm{g} / \mathrm{mL}$ de PGF2 $\alpha$ ) em solução tampão Tris-HCl 0.05M (Fisher BB153-1) com pH 7,5. Alíquotar e armazenar as referências a $-20^{\circ} \mathrm{C}$.

DILUIÇÃO E DETERMINAÇÃO DA CAPACIDADE DE LIGAÇÃO DO ANTICORPO ANTIPGF2 $\alpha$ PARA RADIOIMUNOENSAIOS

$\mathrm{O}$ anticorpo utilizado nos radioimunoensaios de PGF2 $\alpha$ foram gentilmente doados pelo Dr. William Thatcher da Universidade da Flórida. Tal anticorpo estava liofilizado e acondicionado em microtubos. Seguindo as instruções do doador, o anticorpo foi reconstituído em $1000 \mu \mathrm{L}$ de água destilada e desionizada, gerando uma solução final 1:100. 
Para a realização da técnica de radioimunoensaio para PGF2 $\alpha$ recomenda-se que a diluição do anticorpo promova uma capacidade de ligação de aproximadamente $30 \%$. Assim, foram feitos estudos preliminares testando as seguintes diluições de anticorpo: 1:1000; 1:2000, 1:4000, 1:8000 e 1:16000. Os testes foram realizados seguindo-se o procedimento para radioimunoensaio para PGF2 $\alpha$ descrito abaixo e a diluição determinada como a mais adequada foi de 1:4000. Tal diluição foi utilizada em todos os ensaios subseqüentes.

\section{DETERMINAÇÃO DA CONCENTRAÇÃO PGF2 $\alpha$ NO MEIO DE CULTURA POR RADIOIMUNOENSAIO}

A - Preparar uma curva padrão com tampão Tris-HCl 0.05M pH 7,5 com quantidades conhecidas de PGF2 $\alpha$ não radioativa $(15.1 ; 31.2 ; 62.5 ; 125 ; 250 ; 500 ; 1000 ; 2000 ; 4000$; 8000 pg/mL). Para cada tubo são utilizados $100 \mu \mathrm{L}$, assim em duplicata utiliza-se $200 \mu \mathrm{L}$, de cada uma das soluções. Preparar as soluções com as diferentes concentrações de PGF2 $\alpha$ da seguinte maneira: $8000 \mathrm{pg} / \mathrm{mL}(1984 \mu \mathrm{L}$ de Tris- $\mathrm{HCl}+16 \mu \mathrm{L}$ da solução estoque com $1 \mu \mathrm{g} / \mathrm{mL}$ de PGF2 $\alpha) ; 4000 \mathrm{pg} / \mathrm{mL}(1000 \mu \mathrm{L}$ de Tris-HCl $+1000 \mu \mathrm{L}$ da solução com $8000 \mathrm{pg} / \mathrm{mL}$ de PGF2 $\alpha) ; 2000 \mathrm{pg} / \mathrm{mL}(1000 \mu \mathrm{L}$ de Tris- $\mathrm{HCl}+1000 \mu \mathrm{L}$ da solução com 4000pg/mL de PGF2 $\alpha) ; 1000 \mathrm{pg} / \mathrm{mL}(1000 \mu \mathrm{L}$ de Tris-HCl $+1000 \mu \mathrm{L}$ da solução com $2000 \mathrm{pg} / \mathrm{mL}$ de PGF2 $\alpha) ; 500 \mathrm{pg} / \mathrm{mL}(1000 \mu \mathrm{L}$ de Tris-HCl $+1000 \mu \mathrm{L}$ da solução com $1000 \mathrm{pg} / \mathrm{mL}$ de PGF2 $\alpha)$; $250 \mathrm{pg} / \mathrm{mL}(1000 \mu \mathrm{L}$ de Tris-HCl $+1000 \mu \mathrm{L}$ da solução com $500 \mathrm{pg} / \mathrm{mL}$ de PGF2 $\alpha) ; 125 \mathrm{pg} / \mathrm{mL}$ $(1000 \mu \mathrm{L}$ de Tris- $\mathrm{HCl}+1000 \mu \mathrm{L}$ da solução com $250 \mathrm{pg} / \mathrm{mL}$ de PGF2 $\alpha ; 62,5 \mathrm{pg} / \mathrm{mL}(1000 \mu \mathrm{L}$ de Tris- $\mathrm{HCl}+1000 \mu \mathrm{L}$ da solução com $125 \mathrm{pg} / \mathrm{mL}$ de PGF2 $\alpha) ; 31,25 \mathrm{pg} / \mathrm{mL}(1000 \mu \mathrm{L}$ de Tris$\mathrm{HCl}+1000 \mu \mathrm{L}$ da solução com $62,5 \mathrm{pg} / \mathrm{mL}$ de PGF2 $\alpha)$ e $15,12 \mathrm{pg} / \mathrm{mL}(1000 \mu \mathrm{L}$ de Tris- $\mathrm{HCl}+$ $1000 \mu \mathrm{L}$ da solução com $31,25 \mathrm{pg} / \mathrm{mL}$ de PGF2 $\alpha$ ); 
B - O número máximo de tubos a serem colocados em um ensaio é de 198. Assim, para um ensaio completo numerar tubos de vidro $12 \times 75 \mathrm{~mm}$, revestidos com borosilicato (Fisher 14-961-26), com os números de 1 a 198;

C - Considerando o volume de amostra de meio utilizado o ensaio de $20 \mu \mathrm{L}$ pipetar $280 \mu \mathrm{L}$ de Tris- $\mathrm{HCl}$ nos tubos referentes ao NSB (No Specific Binding; tubos 1 a 3);

D - Pipetar $280 \mu \mathrm{L}$ de Tris- $\mathrm{HCl}$ nos tubos referentes ao TC (Total Count; tubos 4 a 6);

E - Pipetar $180 \mu \mathrm{L}$ de Tris- $\mathrm{HCl}$ nos tubos referentes ao Bo (Binding; tubos 7 a 9);

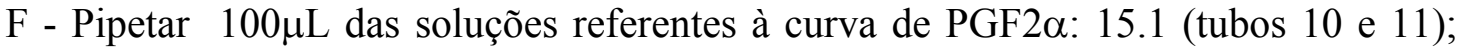
31.2 (tubos 12 e 13); 62.5 (tubos 14 e 15); 125 (tubos 16 e 17); 250 (tubos 18 e 19); 500 (tubos 20 e 21); 1000 (tubos 22 e 23); 2000 (tubos 24 e 25); 4000 (tubos 26 e 27); 8000 (tubos 28 e 29);

G - Pipetar $100 \mu \mathrm{L}$ das soluções referência de PGF2 $\alpha$ : 250pg/mL (tubos 30 e 31), $1000 \mathrm{pg} / \mathrm{mL}$ (tubos 32 e 33), 3500pg/mL (tubos 34 e 35);

H - Pipetar $20 \mu \mathrm{L}$ de cada amostra de meio de cultivo a ser mensurada em duplicata dos tubos 36 ao 192;

I - Pipetar $100 \mu \mathrm{L}$ das soluções referência de PGF2 $\alpha$ : 250pg/mL (tubos 193 e 194), 1000pg/mL (tubos 195 e 196), 3500pg/mL (tubos 197 e 198);

J - Pipetar $20 \mu \mathrm{L}$ de meio KHB nos tubos NSB (tubos 1 a 3), Bo (tubos 7 a 9), nos referentes à curva padrão (tubos 10 a 29) e referências (tubos 30 a 35 e 193 a 198);

$\mathrm{K}$ - Pipetar $80 \mu \mathrm{L}$ de Tris- $\mathrm{HCl}$ nos tubos referentes à curva (tubos 10 a 29) e as referências (tubos 30 a 35 e 193 a 198) e $180 \mu \mathrm{L}$ em cada um dos tubos contendo as amostras (tubos 32 ao 196);

L - Preparação de uma solução de anticorpo para PGF2 $\alpha$ utilizando a seguinte fórmula: Volume inicial (quantidade da solução de Ac 1/100 a ser colocada na solução) x Concentração inicial $(1 / 100)$ = Volume final (quantidade de solução contendo anticorpo que 
deverá ser preparada para todo o ensaio) x Concentração final (1/4000). Para um ensaio com 198 tubos, preparar um volume final de $20 \mathrm{~mL}$, a partir da solução de anticorpo reconstituída em $500 \mu \mathrm{L}$ de $\mathrm{ddH}_{2} \mathrm{O}$ (concentração inicial de 1/100), sendo pré-determinado uma concentração final de 1/4000. Assim, temos a seguinte fórmula: Vi x 1/100=20000 x 1/4000, sendo o Vi $=500 \mu \mathrm{L}$. Diluir $500 \mu \mathrm{L}$ da solução de anticorpo 1/100) em 19.500 $\mu \mathrm{L}$ de Tris-HCl;

M - Preparação de uma solução radioativa de PGF2 $\alpha$, marcada com trício, com uma concentração tal que os tubos TC tenham aproximadamente 15000 desintegrações por minuto (DPM);

$\mathrm{N}$ - Pipetar $100 \mu \mathrm{L}$ da soução de anticorpo previamente preparada em todos os tubos, exceto nos NSB e TC (tubos 1 a 6 ). Homogeneizar o conteúdo dos tubos com velocidade 8 durante 1 minuto (Standard Multi-Tube Vortexer Modelo 58816-115; WWR Scientific Products);

O - Adição de $100 \mu \mathrm{L}$ da solução de PGF2 $\alpha$ marcada com trício em todos os tubos. Homogeneizar o conteúdo dos tubos com velocidade 8 durante 1 minuto (Standard MultiTube Vortexer Modelo 58816-115; WWR Scientific Products). Deixar os tubos em temperatura ambiente durante 30 minutos. Em seguida, incubar os tubos a $4{ }^{\circ} \mathrm{C}$ durante $12 \mathrm{a}$ 18 horas;

P - Após a incubação separar os tubos TC e acondicionar a $4^{\circ} \mathrm{C}$. Preparação de uma solução contendo 0,25g de Carvão-Dextran (Sigma C334) e 0,025g de Dextran (Sigma D4751) em $100 \mathrm{~mL}$ de Solução tampão Tris- $\mathrm{HCl}$ 0,05M, agitada a $4^{\circ} \mathrm{C}$ durante 20 minutos. Adicionar em todos os tubos, exceto nos $\mathrm{TC}, 500 \mu \mathrm{L}$ de tal solução não demorando mais do que 4 minutos, momento em que as amostras devem ser imediatamente centrifugadas;

Q - Centrifugação dos tubos a 2900 x g, durante 15 minutos a $4^{\circ} \mathrm{C}$. Adicionar $500 \mu \mathrm{L}$ de Solução tampão Tris-HCl nos tubos TC e homogeneizar o conteúdo dos tubos com 
velocidade 8 durante 1 minuto (Standard Multi-Tube Vortexer Modelo 58816-115; WWR Scientific Products);

$\mathrm{R}$ - Após a centrifugação inverter o conteúdo dos tubos de vidro em tubos plásticos próprios para contagem (Sarstedt 58536), previamente numerados de 1 a 198 e acomodados em seqüência numérica nas estantes do contador ;

S - Adição de 4mL do líquido de cintilação (Opthifase "Hi Safe", Perkin Elmer, 0311586) aos tubos de plástico. Tal procedimento deve ser realizado dentro da capela. Fechar os tubos com tampas próprias (Sarstedt 65802) e homogeneizar com movimentos de inversão;

T - Realização da programação do contador (Wallac $®$, modelo 1409-11) e contagem da quantidade de radiação presente em cada tubo.

Os tubos NSB não recebem anticorpo, mas recebem PGF2 $\alpha$ triciada e carvão para a determinação da quantidade de ligações inespecíficas realizadas pela PGF2 $\alpha$ triciada. Uma vez que o carvão tem uma alta afinidade pela PGF2 $\alpha$ triciada livre, toda a contagem radioativa irá se referir às ligações não específicas, pois não há anticorpos nestes tubos. Este procedimento é de extrema importância para um ensaio, pois tal valor será descontado do valor médio aferido em cada um dos tubos do ensaio.

Os tubos TC não recebem anticorpo e carvão, mas recebem PGF2 $\alpha$ triciada. Não havendo carvão para "seqüestrar" a PGF2 $\alpha$ triciada, toda a radiação presente será aferida pelo contador de radiação beta, indicando, a radiação total do tubo.

Os tubos Bo possuem anticorpo, PGF2 $\alpha$ triciada e carvão. Não havendo PGF2 $\alpha$ a não ser a triciada não haverá competição, e esta se ligará ao anticorpo presente. Assim, determinase a capacidade máxima de ligação do anticorpo com a PGF2 $\alpha$, seja ou não triciada.

Após a aferição da radiação pelo contador, é realizada a trnasferência do valor das contagens para uma planilha própria do programa "Quatro Pro". Este programa monta uma curva padrão que é então utilizada para transformar os dados em DPM (Desintegrações por 
minuto) para pg/mL de PGF2 $\alpha$. Com a curva padrão é elaborada uma equação de regressão obtida relacionando-se as quantidades de ligante com as contagens radiativas obtidas. A concentração de ligante nas amostras é obtida substituindo o valor da contagem na equação de regressão. 
ANEXO A6 PROTOCOLO DE CULTIVO DE CÉLULAS ENDOMETRIAIS BOVINAS "BEND CELLS"

\section{PREPARAÇÃO DO MEIO DE CULTIVO}

A - Sobre uma base de agitação colocar um beaker contendo $1400 \mathrm{~mL}$ de água bidestilada e desionizada e um agitador magnético. Adicionar a água 10,7g de meio F-12 (Sigma N6760) e 9,62g de meio MEM (Sigma M0643) agitando até a completa homogeneização. Adicionar 400UI de insulina (Sigma I5500) e 3,37g de $\mathrm{NaH}_{2} \mathrm{CO}_{3}$ (Fisher BP3281). Ajustar o pH dessa solução para 7,3. Em seguida, adicionar água bidestilada e desionizada até completar o volume final de 1600mL. Filtrar 4 alíquotas de $400 \mathrm{~mL}$ em garrafas de $500 \mathrm{~mL}$ previamente autoclavadas. Armazenar o meio a $4^{\circ} \mathrm{C}$;

B - Para o crescimento e multiplicação das células foi utilizado o meio de cultivo suplementado com soro, para tanto a finalização do preparo do meio é realizada imediatamente antes do uso. Retirar $5 \mathrm{~mL}$ do meio de cultura (para restarem no frasco 395mL). Adicionar ao meio 50mL de Soro Fetal Bovino (FBS; Gibco Life 10270-106), 50mL de soro eqüino (Nutricel) e $5 \mathrm{~mL}$ de uma solução antibiótica e antimicótica (Sigma A7292). O meio de cultivo assim preparado é denominado "MEIO COMPLETO COM SORO" e pode ser armazenado a $4^{\circ} \mathrm{C}$ por até duas semanas. No momento da utilização, o meio deverá ser aquecido a $37^{\circ} \mathrm{C}$ em banho-maria;

C - Para a administração dos tratamentos é utilizado o meio de cultivo não suplementado com soro. No momento da utilização do meio, retirar $5 \mathrm{~mL}$ do meio de cultura (para restarem no frasco $395 \mathrm{~mL}$ ). Adicionar ao meio $100 \mathrm{~mL}$ de água bidestilada e desionizada esterelizada e $5 \mathrm{~mL}$ de uma solução antibiótica e antimicótica (Sigma A7292). O meio de cultivo assim preparado é denominado "MEIO COMPLETO SEM SORO" e pode 
ser armazenado a $4^{\circ} \mathrm{C}$ por até duas semanas. No momento da utilização, o meio deverá ser aquecido a $37^{\circ} \mathrm{C}$ em banho-maria.

\section{PROCEDIMENTOS GERAIS PARA O CULTIVO DE CÉLULAS BEND}

A - As células se encontram inicialmente acondicionadas em criotubos (Corning 430659) armazenados em nitrogênio líquido. Para descongelar as células imergir o criotubo em água a $37^{\circ} \mathrm{C}$ (banho-Maria) e verter o criotubo a cada 30 segundos até o total descongelamento do seu conteúdo. Sob fluxo laminar, em um frasco de cultivo T25 (Corning 430639 ) colocar $5 \mathrm{~mL}$ do "Meio Completo com Soro", previamente aquecido a $37^{\circ} \mathrm{C}$. Fechar o frasco e levar a estufa a $38,5^{\circ} \mathrm{C}$, com atmosfera umidificada contendo $5 \%$ de $\mathrm{CO}_{2}$. Após 24 horas retirar o meio de cultivo do frasco e adicionar $5 \mathrm{~mL}$ de meio fresco. Deixar as células em incubação até atingirem $90 \%$ de confluência, o que ocorre em aproximadamente 4 dias; momento em que as células devem ser removidas do frasco por tripsinização;

B - Preparação de uma solução de tripsinização, diluindo na proporção de 1:10 a tripsina 2,5\% (Gibco 15090-046) em meio Puck's [1,6g de NaCl (Fisher BP358), 0,08g KCl (Fisher BP3661), 0,07g $\mathrm{NaHCO}_{3}$ (Fisher BP328-1), 0,2g Glucose (Sigma G6152), 0,04g EDTA (Fisher, BP120500) e 0,001g de vermelho de fenol (Sigma P5530); pH 7,4] de forma a se obter uma solução de tripsina $0,25 \%$ em meio Puck's;

C - Remoção do meio de cultivo antigo e adição de $2 \mathrm{~mL}$ de uma solução com $0,25 \%$ de tripsina, previamente aquecida a $37^{\circ} \mathrm{C}$, no frasco de cultivo e levar a estufa durante 10 minutos. Após esse tempo, bater levemente no fundo do frasco para desalojar as células. Caso as células não estejam completamente desprendidas do fundo do frasco, adicionar mais $2 \mathrm{~mL}$ de solução de tripsina e levar o frasco novamente a estufa durante 10 minutos. Em seguida, 
adicionar a solução de tripsina ao meio de cultivo completo com soro, em volume igual a solução de tripsina utilizada, procedimento que objetiva neutralizar os efeitos da tripsina;

D - Realizar a transferência do conteúdo do frasco para tubos de 15mL (Fisher 05539-6), centrifugar a 500 x $g$, durante 10 minutos. Depois da centrifugação remover o meio de cultivo deixando somente o "pellet" celular formado;

E - Ressuspender o "pellet" em $4 \mathrm{~mL}$ de meio de cultivo completo com soro e transferir esta suspensão de células para um frasco T175 (Sarstedt 831882.002). Adicionar $50 \mathrm{~mL}$ do meio completo com soro e incubar em estufa a $38,5^{\circ} \mathrm{C}$, com atmosfera umidificada contendo $5 \%$ de $\mathrm{CO}_{2}$. O meio de cultivo deve ser trocado periodicamente, conforme alteração de $\mathrm{pH}$ do mesmo observada pela mudança de coloração. As células devem permanecer no frasco T175 por aproximadamente 7 dias, até que seja atingida uma confluência de $90 \%$. Neste momento as células devem ser novamente tripsinizadas;

F - A tripsinização das células cultivadas em frasco T175 é feita de forma semelhante a realizada em frascos $\mathrm{T} 25$, entretanto, para o frasco T175 utilizar um volume de tripsina $0,25 \%$ de $10 \mathrm{~mL}$, podendo ser duplicado caso as células não se desalojem adequadamente;

G - Para o congelamento das células após a ressuspensão das mesmas no meio de cultivo, colocar uma alíquota desta suspensão $(20 \mu \mathrm{L})$ no hematocitômetro e determinar o número total de células. Ressuspender as células em soro fetal bovino na concentração de 4 milhões de células por $\mathrm{mL}$ de soro. A seguir, para cada um $\mathrm{mL}$ de suspensão de células gotejar vagarosamente um $\mathrm{mL}$ de uma solução de dimetilsulfóxido (DMSO) em soro fetal bovino $20 \%(\mathrm{v} / \mathrm{v})$. Alojar as células em criotubos, contendo $1 \mathrm{~mL}$ de suspensão cada um $(2 \mathrm{x}$ $10^{6}$ células). Identificar cada criotubo com data, nome e número de passagem. Manter as células a $-20^{\circ} \mathrm{C}$, durante 2 horas e então armazenar os criotubos em nitrogênio líquido. Anotar o local de armazenamento, número de repiques, data, nome do responsável pelo processo de congelamento; 
H - Descongelar uma das alíquotas congeladas e proceder conforme o ítem A, objetivando avaliar a viabilidade das células após o procedimento de congelamento. 